THE GTANT FISH OF
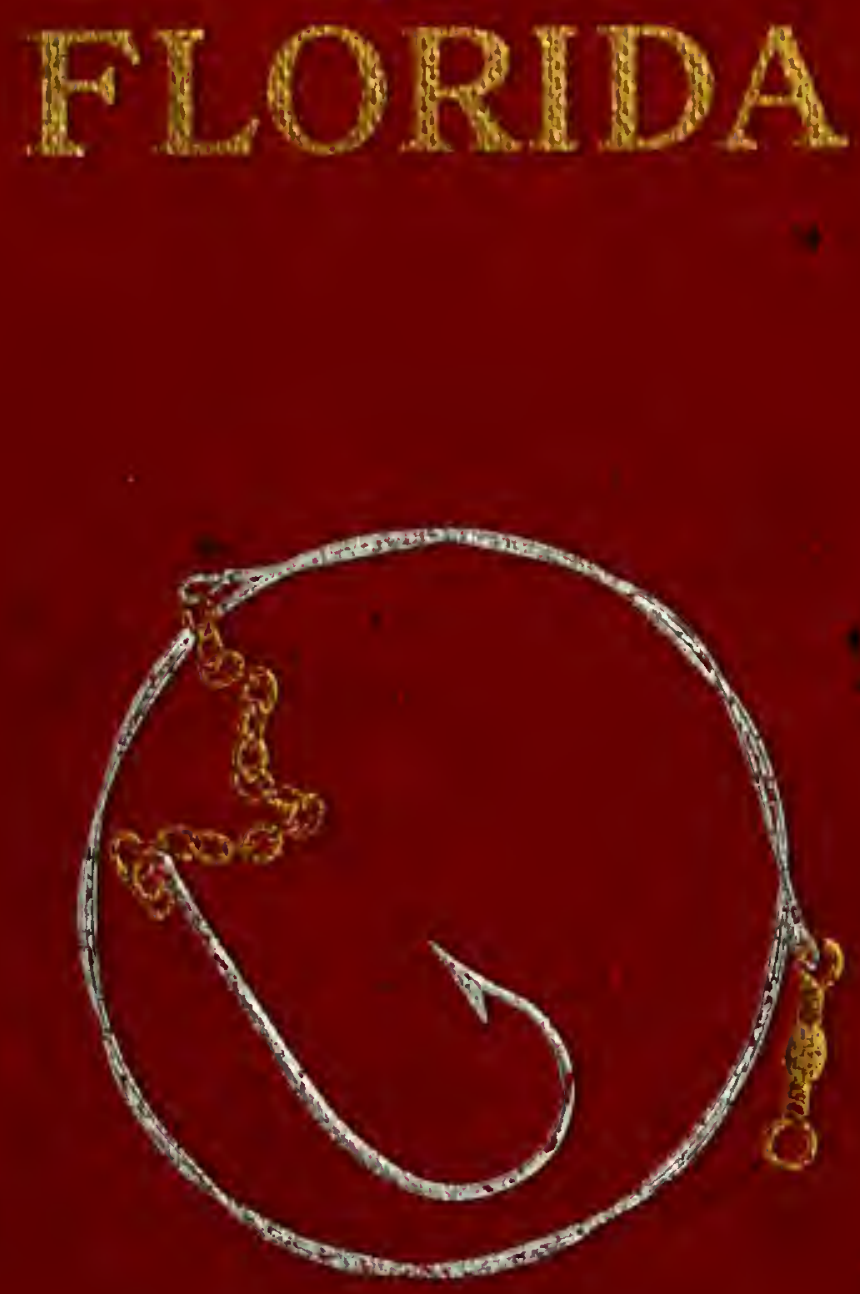

d. Turner-Turner 


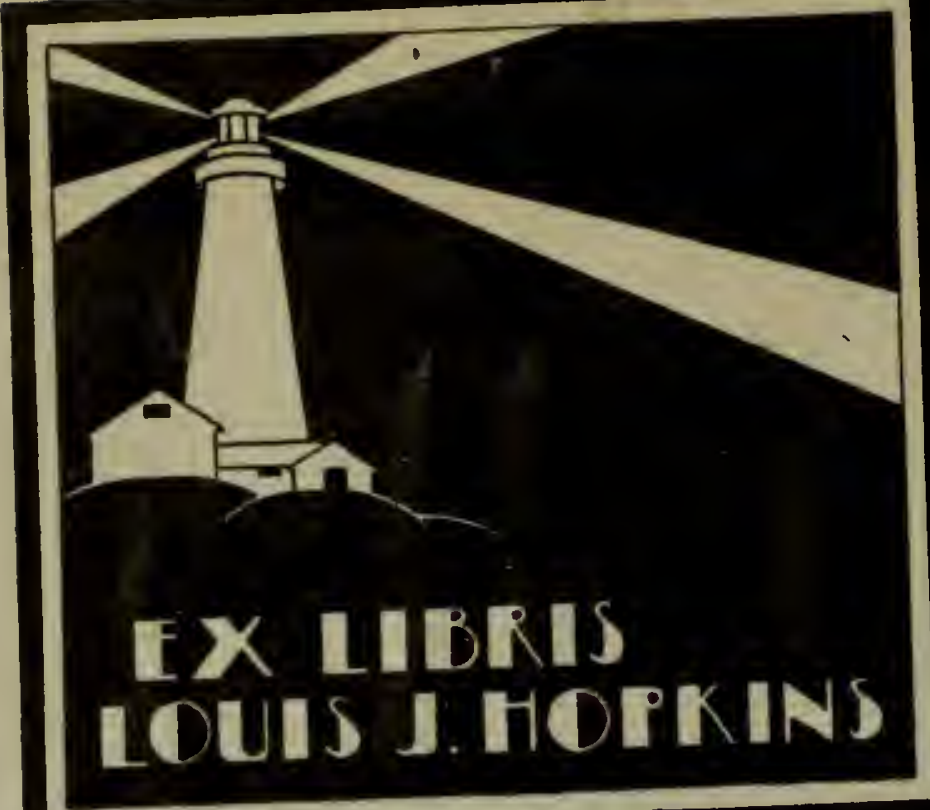

JPAN LAMONI

\section{THE LIBRAKY}

HAM YOUNG UNIVERSITY

PROVO, UTAH

$$
\text { e }
$$



• 



THE GIANT FISH OF

FLORIDA 




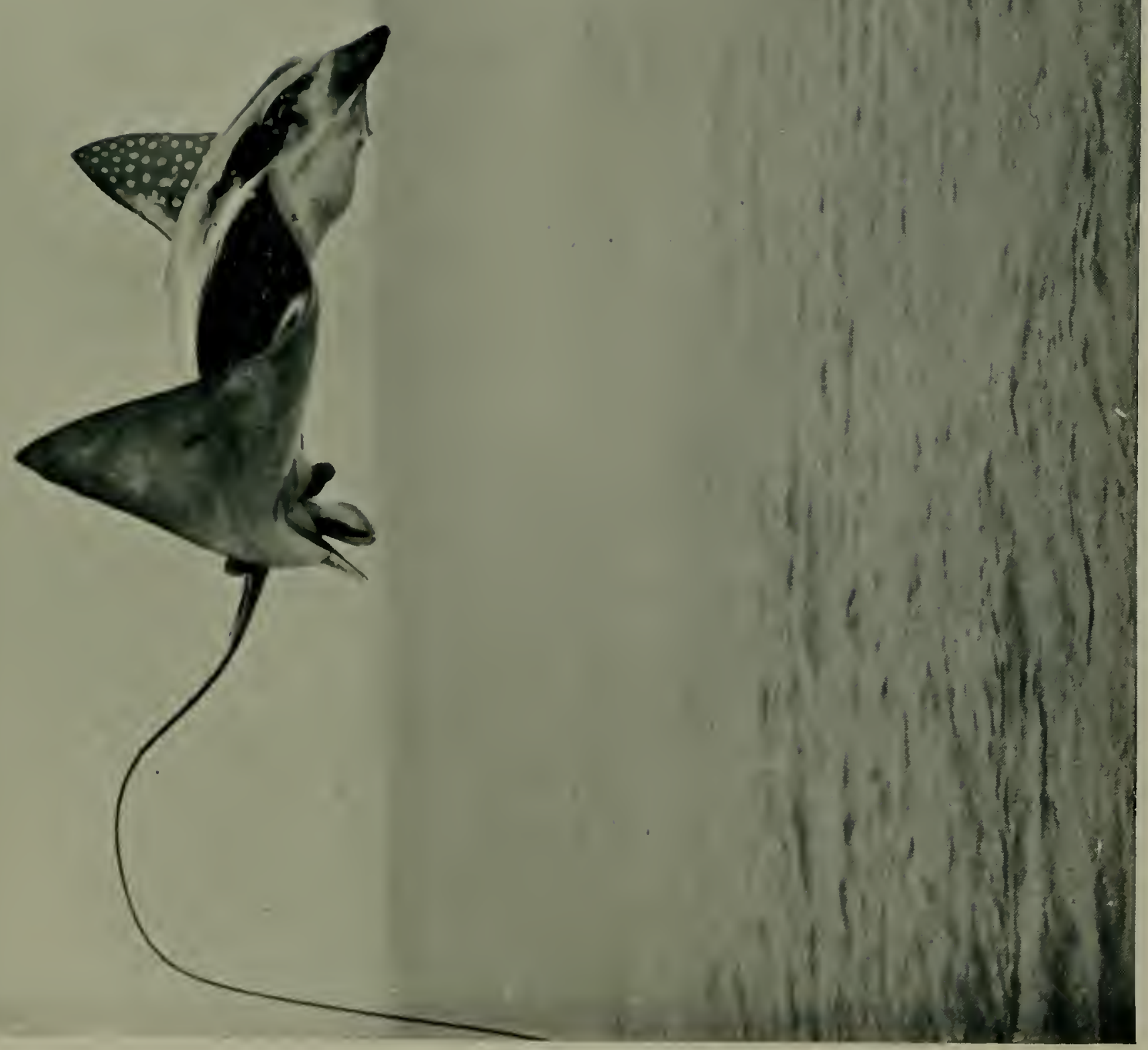

点 
OF

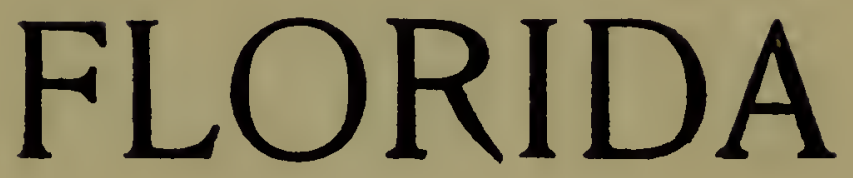

BY

J. TURNER-TURNER

WI TH 48 ILLUSTRATIONS

LONDON

C. ARTHUR PEARSON LTD.

HENRIETTA STREET

I 902 


\section{PREFACE}

THE sea has its big game as well as the land, and there are some of us-the name of Mr. W. H. Grenfell, M.P., at once occurs in this connection-who have derived much sport from its pursuit. Whether, as Mr. Grenfell and others would seem to indicate, the tunny of the Mediterranean, which is identical with the tuna of American waters, may yet be recognised as a sporting fish by British anglers has to be seen ; meanwhile the coast of America, and more particularly that of Florida and Mexico, is the recognised resort of those who angle for the biggest that the sea has to give.

In this volume I have endeavoured to lay before fellow sportsmen at home some of the charms of fishing for tarpon and the other rangers of the Gulf. The tarpon, of course, 


\section{Preface}

stands first; indeed, there are many visitors to those parts who will fish for nothing else, thus losing many excellent opportunities of sport on days that are too rough for them to get out on the tarpon grounds. No attempt has been made at anything in the nature of an exhaustive list of the sea fish of Florida, which might easily have been gathered from one or other of the American standard works on the subject, such as the invaluable volumes by Jordan and Evermann, published under the auspices of the United States National Museum. Only'fish that are likely to attract the notice of the angler have been figured and briefly described, and this from the sporting rather than from the natural-history point of view. Nor have I devoted much space to the remaining fauna of the coast and islands; although a few conspicuous birds like the cormorant and pelican, and an occasional reptile, such as the turtle and alligator, the pursuit of which may pass an otherwise wasted hour, have claimed a place in these notes.

Much interest attaches to the realistic photographs with which these pages are illustrated. One of the first anglers in this country to inspect them was Mr. F. G. Aflalo, a fishing enthusiast to whom I am indebted in no small measure for the final arrangement of my notes, and he at once pronounced them to be certainly the most remarkable in their own way that had ever passed through his hands. They are all from the natural (not mounted) fish, and the effects were obtained by a simple, though careful, arrangement of pegs and sheeting. 


\section{Preface}

I think that I may claim for them a correctness that, while combining the impressions of both, could never have been obtained by either the brush or camera unaided. My thanks are also due to Professor George A. Boulenger, who, with Mr. Aflalo, identified as far as possible the subjects of my photographs.

There are but one or two really successful photographers of living fish under water, and these artists must obviously confine their efforts to comparatively small fish in the confinement of aquarium tanks. Now, a considerable observation of fish at home and abroad under every variety of conditions has persuaded me (though I hardly expect the statement to pass unchallenged) that the narrow confines of the aquarium tank tend to cramped and unnatural attitudes in the subjects; and this contention seems to me abundantly substantiated by a careful comparison of the otherwise excellent photographs from time to time published, and the best studies of the best fish painters. My own system of illustration combines the two, and in great measure, I venture to think, obviates many of the faults of both. Constant observation of the fish in their natural habitat impresses on me their every attitude, and, while unfortunately not possessed of the necessary talent to transfer these groups to canvas, there is no insuperable difficulty in the way of pegging the various subjects in just the positions they assumed before my eyes an hour or two earlier. The camera does the rest. 


\section{Preface}

Tarpon fishing is still in its infancy. New methods and grounds will be discovered. Meanwhile, it is a congenial task to tell the story of the big fish of Florida seas, not from hearsay or printed reports, but from personal and vivid experience.

$$
\text { J. T. T. }
$$

Cavalry Club, Christmas, 1901. 


\section{CONTENTS}

\section{Preface.}

CHAPTER I.-The Giant TaRpon.

$" \quad$ II.-Among the Alligators

" III.-How to Catch Tarpon.

" IV.-A Lively Morning in the Pass.

" V.-Ladies who Love the Sport.

$"$ VI.-Enormous Rays or Devil-Fish.

" VII.-Harpooning a Monster.

" Vili.-The Loggerhead Turtle.

$"$ IX.-Catfish as Scavengers.

" X.-Bony Fish-Jack-Garfish-Jewfish-SqueateagueAND BASS.

" XI.-Spotted Eels - Crab-eaters - Surf-whiting - MoonFISH-LEATHER JACKETS-TRIGGER-FISH一AND MulLet.

" XiI.-Striped Mullet-Sharks-Bird Life.

INDEX. 


\section{LIST OF ILLUSTRATIONS}

I. A Whip Ray Leaping $\ldots \quad$.. $\quad \ldots \quad$ Frontispiece

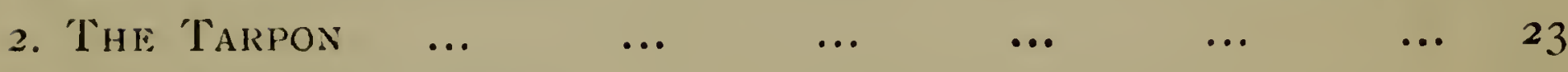

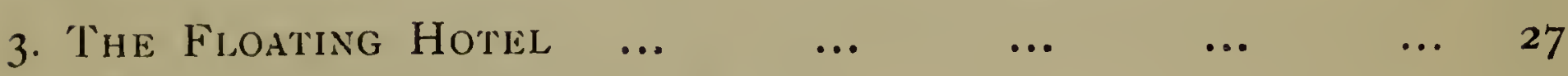

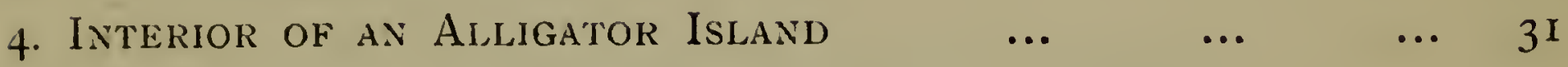

5. The Alligator made straight for the Open Sea $\quad \ldots \quad 37$

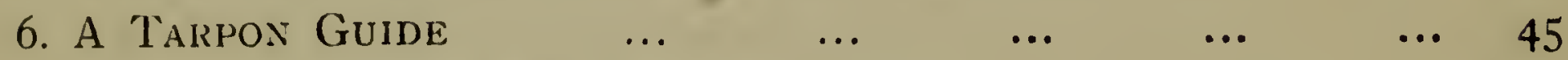

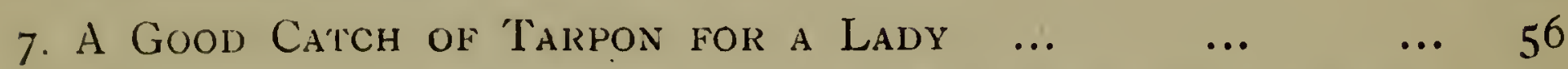

8. A Hooked Piece of Cokal which was mistaken for a Jewfish 57

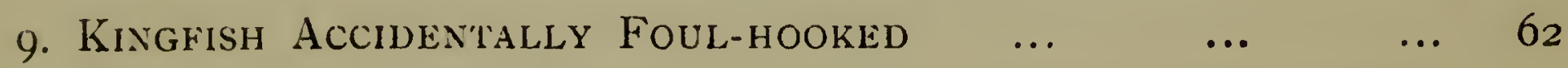

io. With Lighting Speed the Kinghish Chased the Lively

$\begin{array}{lllllllll}\text { SKIPJACK } & \ldots & \ldots & \ldots & \ldots & \ldots & \ldots & 63\end{array}$

II. The Kingfish Leapt sone Twenty Feet into the Air $\ldots 67$

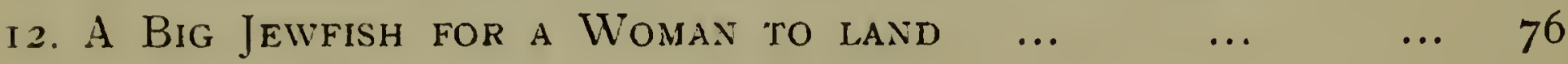

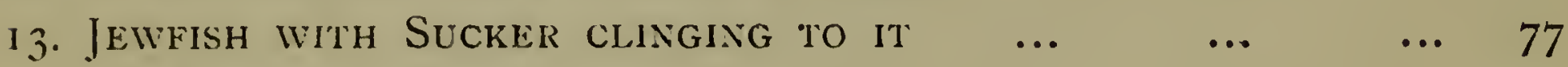

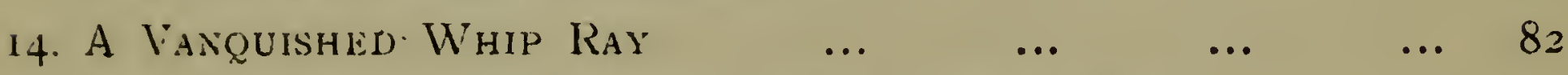

15. The Whip Ray tURNed helplessly on its Back $\ldots . \quad \ldots \quad \ldots 3$

16. The Houken Tarpon rollowed the Boat towards Shore... 83

17. The Crews of Six Boats tolving a Harpooned Whip Ray 83

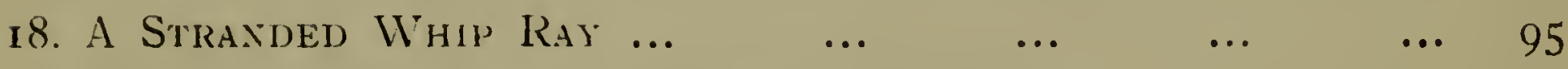

i9. Harpouned Devil-fish in Shallow Water $\quad \ldots \quad \ldots \quad \ldots \quad$ IO2

20. Harpouned Devil-mish with Jaws propped open $\ldots \quad \ldots \ldots l$ lo

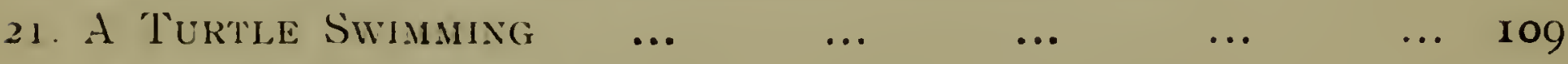

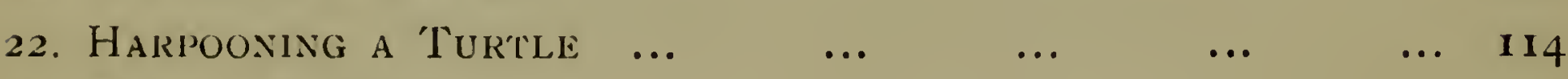

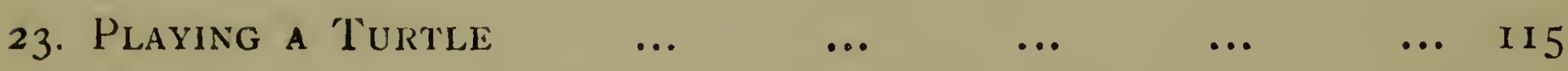

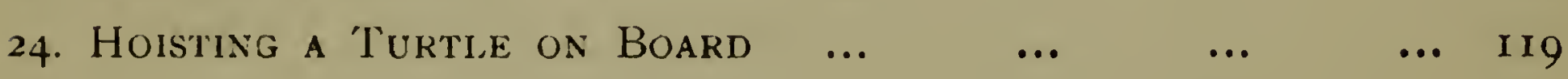




\section{List of Illustrations}

25. Dean Grouper being Devoured by Catfish and Brfam ... 127

26. Gaff Topsail Catfish ani) Young Hammerhead Shakk $\ldots$ I 3 I

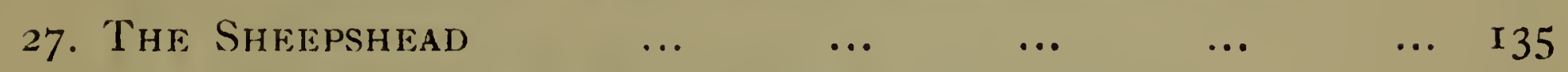

28. Toad Fish Watching Bony Fish as they Leap $\ldots . \quad \ldots \quad \ldots \quad$ I 39

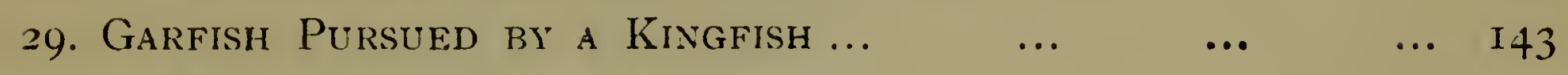

30. A Marmoratus Lying Motionless $\quad \ldots \quad \ldots \quad \ldots \quad \ldots$ i 46

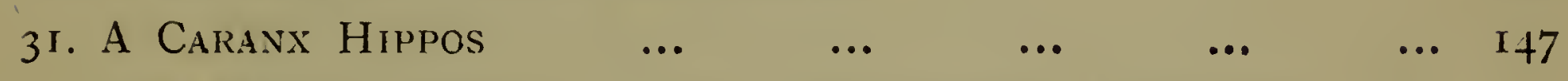

32. The Mighty Perch and his Deep-water Companion, the

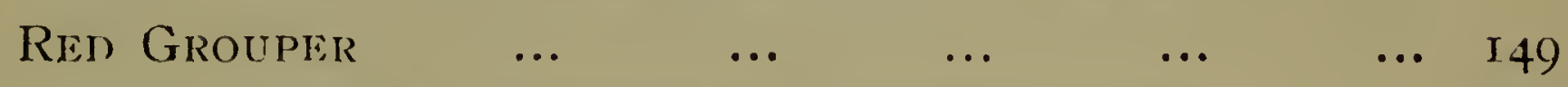

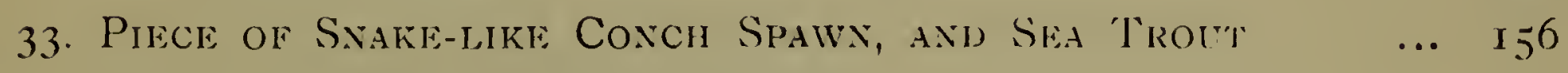

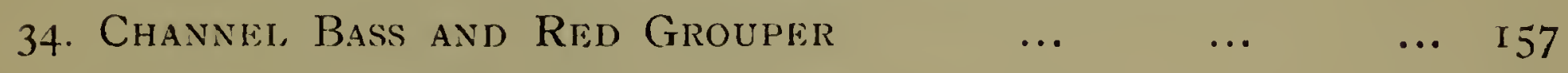

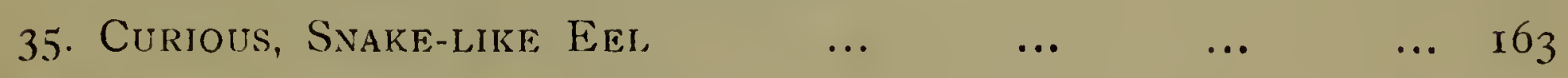

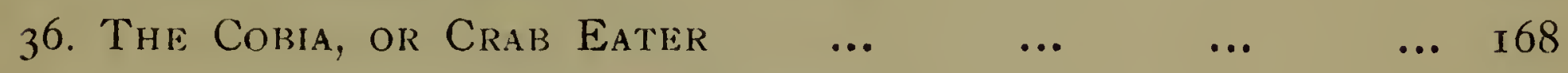

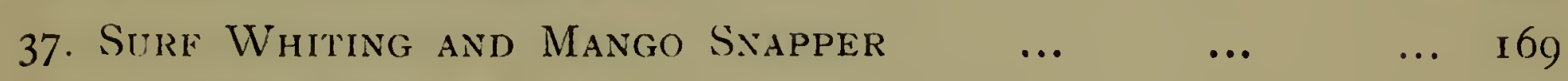

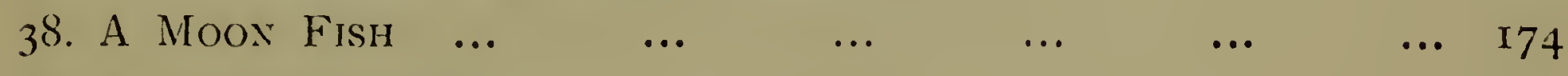

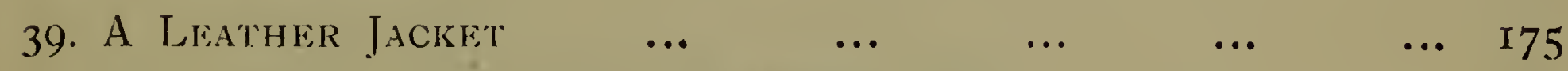

40. The Trigger Fish and the Angel Fish $\ldots . \quad \ldots \quad \ldots$ i 80

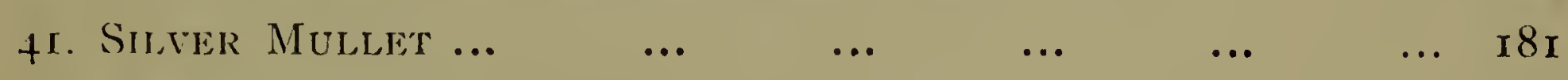

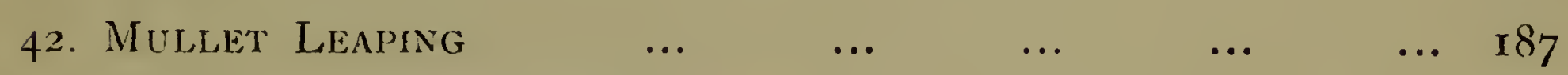

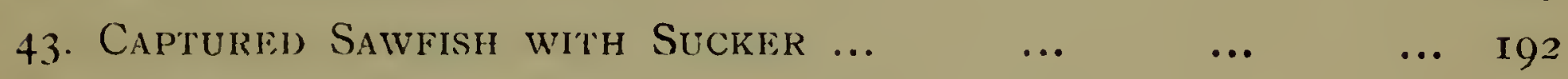

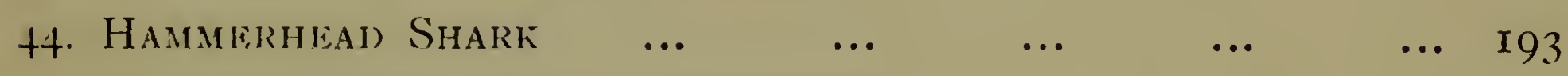

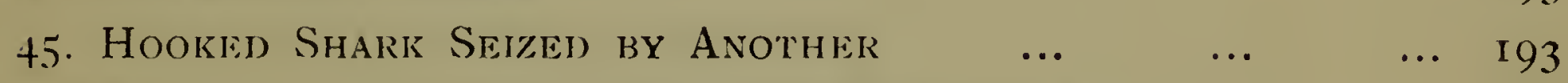

46. Extracting a firmly embedded Hook from a ShakK _.. I98

47. Ald, Hands Give the Shark a Mighty Heave Ashore _..

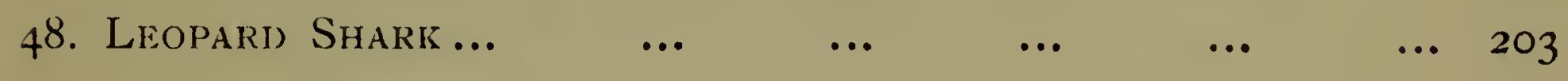





\section{The Giant Tarpon}

\section{CHAPTER I}





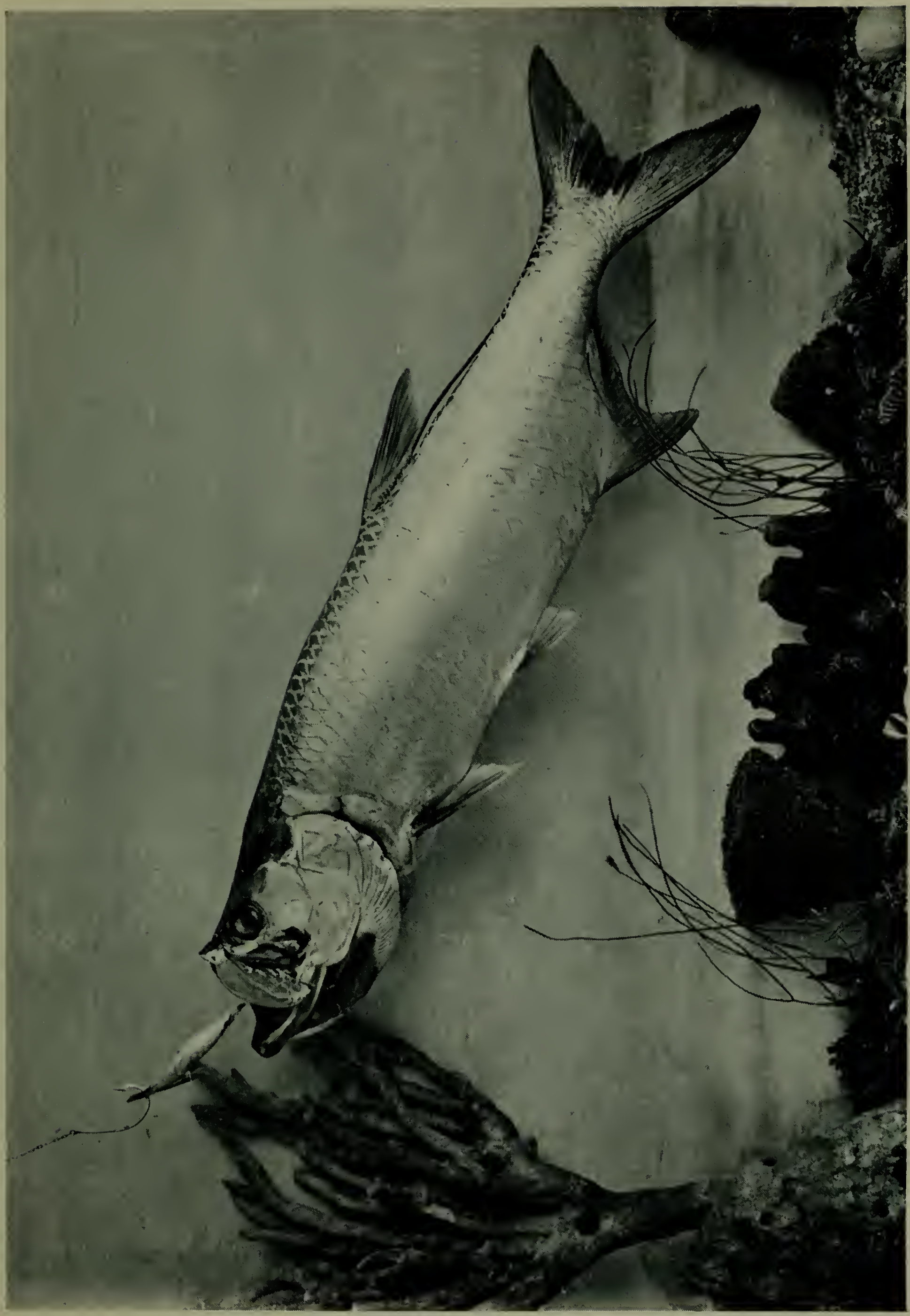

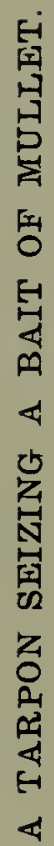





\section{CHAPTER I}

THE GIANT TARPON

IN the old country the sport of sea-fishing, though yearly more popular with its own votaries, can never oust the sport on inland waters, until at any rate these are fished out. Always excepting sharks as vermin, there is no British sea fish so mighty as the salmon, or so game as the trout. American waters, however, provide more than one salt-water giant calculated to test, if not, perhaps, the finest skill, yet certainly the greatest endurance that man is likely to bring to its capture. Of these, the big game of the Atlantic, the tarpon stands easily first.

Better than any detailed description of the fish and dentition, with measurements, is its picture to be found in this volume. Suffice it to say that the tarpon is to all outward appearance, bar the long dorsal fin ray, a gigantic 


\section{Giant Fish of Florida}

herring, with scales four inches in diameter. It may weigh over two hundred pounds, and the length of such a monster would be about seven feet. The qualities that recommend the tarpon to the sportsman are-first, its power of leaping clear of the water, which lends excitement to its pursuit, since it may, and not infrequently does, land in your boat; and further, its mighty strength, endurance, and cunning, which combine to render it a worthy antagonist. It will, very often, indeed, completely tire out an angler, who then hands the rod to his guide, leaving him to finish off the half-exhausted fish, an alliance that, however unsporting it may seem to the hypercritical, may be absolutely necessary if the fish, or, indeed, the tackle, is to be saved. Not that the fish, except as a trophy, is of much use when gaffed. As food it is of little worth, and it is quite a pity that the pioneers in tarpon fishing should have thought it necessary to gaff through the gills and kill every fish, and leave it dead on the foreshore. Nowadays a more economic and sporting spirit prevails, and fish are often landed without being gaffed at all, and then allowed to go free.

Attempts have from time to time been made to compare tarpon and salmon fishing, to the advantage of one or the other, but the fact is that no such comparison is possible. As well compare shooting trap pigeons and rocketing pheasants. The salmon calls for skill, experience, and light tackle; the 


\section{Giant Fish of Florida}

tarpon requires no skill and no experience, but the very strongest of tackle. It also taxes the angler's strength and staying power to an extent that would, save in very exceptional circumstances, be out of the question in salmon fishing. And why, after all, any call for these eternal comparisons? To every country and season and income their fish ; and those who have the opportunities may without difficulty kill their Florida tarpon and their Highland salmon in the same summer. Nor is the tarpon, though first, the only fish worth catching in those waters, and I have purposely devoted a page here and there to the sport obtainable with smaller species, and even with the harpoon.

The best time of tide for sea-fishing at Boca Grand is slack water, and the interval immediately before and after it. A good deal depends on the quarter of the moon and direction of the wind, for it is these that regulate the duration of a fishing-tide. The tides are erratic in those seas ; at times it is possible to fish for three hours on end, while on other days no sooner are you fairly under way than the tide becomes too strong, and there is nothing for it but to reel up and go ashore. Much the same difference is, of course, discernible in sea-fishing at home during a week of spring or neap tides, but there is much greater irregularity on the Florida coast.

Tarpon fishing by night is exciting work, somewhat too exciting for many people. The fish, however, bite with 


\section{Giant Fish of Florida}

far more certainty than by day, particularly when the moon is shining. There is an element of danger about this night fishing, and more than one nervous system has been shattered by a porpoise jumping into a boat; indeed, Mr. Otis Mygatt, one of the most celebrated of tarpon-fishermen, suffered severely from this startling intrusion.

It is impossible to know how far one is drifting towards the open sea, and on all sides are heard the plunges of mighty fish, which are far more likely to land in the boat than during the day. A great tarpon may seize the bait and get round behind the angler, to his utter confusion. Even if the shore is reached in time, there is considerable difficulty and excitement in landing a tarpon on a dark night. Towards the end of May those who are not strong enough to land their tarpon without delay lose them to the sharks. As many as five of these monsters will attack a hooked tarpon at once, and on one occasion I remember four of them while thus engaged attacking a fifth, and in a few moments not a shred of that fifth shark remained. The angler recovered only the head of the tarpon. It is remarkable, seeing the position of the shark's mouth, what rapid bites he can take at a struggling tarpon, just as we should take the first bite of a sandwich. It is no bad plan to carry a rifle in the boat so late in the season. It will often keep off sharks and save a good fish.

A few words must now be said as to the means of reaching Boca Grand Pass, the most fashionable tarpon 


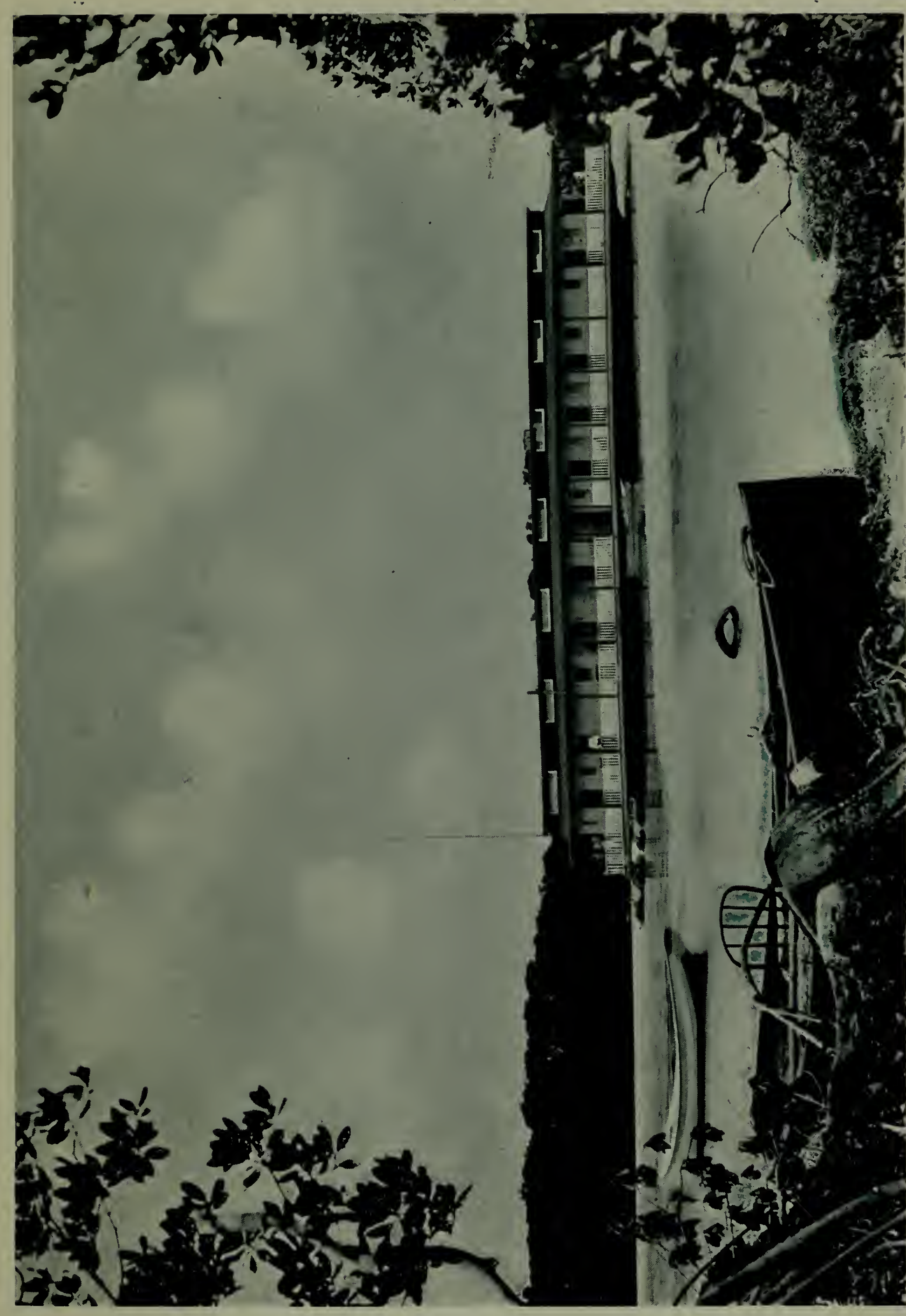

空 



\section{Giant Fish of Florida}

ground of to-day, and as to the accommodation to be had there. There seems to be a mistaken idea that tarpon fishing is an inordinately costly recreation; but this cannot be upheld when it is remembered that the total expenses on the spot amount to little more than thirty shillings a day, including hotel, board and lodging, guide, boat, bait, and guide's keep, while the return fare, with forty hours train and four hours boat after reaching New York, is not more than $\complement_{32}$ out and home.

The Boca Grand Pass was not always the headquarters of tarpon trolling, for this modern method of fishing was first successfully practised some few years ago in the Captiva Pass. There is also good tarpon fishing in Aransas Pass, Mexico, where living and other expenses are much less than at Boca Grand, but the fish run smaller. In I9or Hughes' Floating Hotel was the only accommodation available, with the exception of hired yachts, and, though most comfortable in every way, had certain disadvantages arising out of the spot in which it was moored. There was also, however, to be shortly completed on Museppa Island, about three miles from Boca Grand Pass, a wellappointed hotel, with every modern comfort, including a steamer and launches to convey fishers to and from the Pass. Guides, bait, a photographing room, and shark-proof bathing establishment were among the attractions to be anticipated at this hotel for the next fishing season. 


\section{Giant Fish of Florida}

Tackle for tarpon fishing should, for the present at any rate, be bought of Vom Hofe, of New York. English tackle makers have the matter in view, but it is to be questioned whether the lower prices at which they will one of these days be able to turn out equally good stuff will not be more than neutralised by the excessive duties. The rods cost about $f_{3}$ each, and the reels about $f_{7}$. Money for use during the trip should be sent to the bank at Punta Gorda, a little town with few resources beyond its fashionable hotel. 


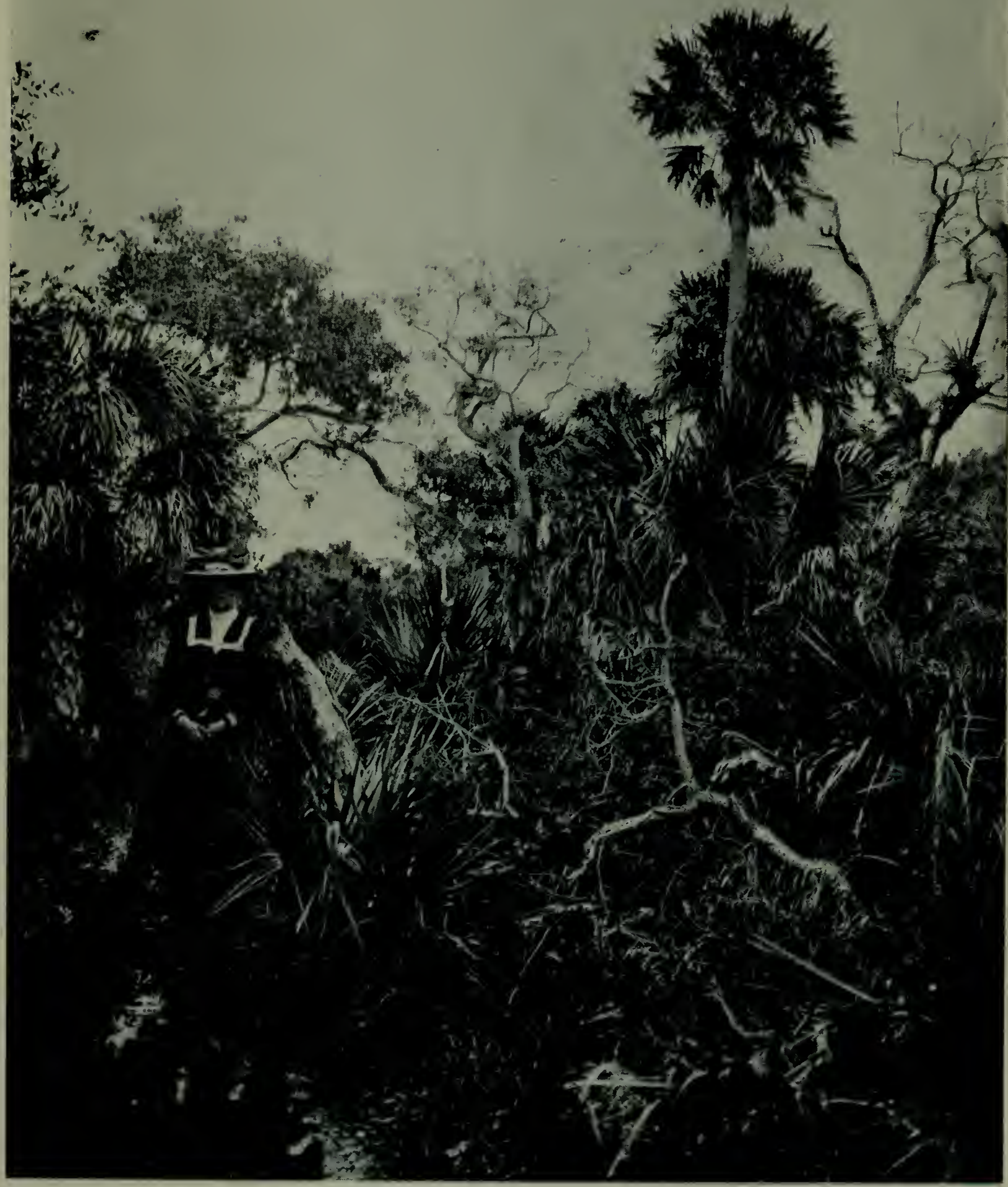

INTERIOR OF AN ALLIGATOR ISLAND. THE HAUNT OF THE RATTLESNAKE, GOPHER, TORTOISE, AND RACCOON. 



\section{Among the Alligators}

\section{CHAPTER II}





\section{CHAPTER II}

\section{AMONG THE ALLIGATORS}

THE scenery of that coast will not be found prepossessing; but some of the islands, though almost repellent from without, with their unvarying fringe of oyster-covered mangrove growth depending in the water, are really beautiful in the interior, where their vegetation presents a luxuriant medley of palms, yucca, cactus, indiarubber trees, and all the wealth of festooned creepers so characteristic of the sub-tropical forest. There are long avenues of cabbage palm, that curious proof of human patience, which leads men willingly to fell a plant fourteen inches thick for the sake of a nut-like heart measuring six inches by three. Many of the pools and swamps in the interior are still the haunts of alligators, though the ranks of those hideous reptiles have been greatly thinned by the professional skin hunters. 


\section{Giant Fish of Florida}

A 'gator hunt is not bad fun on an off day, even though the twelve-foot veterans are now few and far between. If pursued on the shore, the alligator will almost certainly make good its escape into the sea, though how it fares with the ever-attendant sharks has not yet been determined. The first requisite for an alligator hunt inland is to enlist the services of a professional hunter, which your guide can easily do, though the only obvious qualification of that official seems to lie in the sanguine but unrealisable assurance that he gives, that every submerged cave contains a quarry. The only equipment for this "sport" is a strong gaff and a fourteen-foot sprit from the boat. You then pick your way through tangled undergrowth, disturbing many a mocassin snake that glides away on your approach.

At every likely puddle the professional one holds his nose and emits a series of fearful grunts, with the object of attracting the wayward reptile. As this expert trick usually fails, the only plan is to make fast the gaff to the sprit, and carefully probe every hole and cave, exploring crevices in the dry earth that look no bigger than large rabbit earths. At length, if success is to be yours, the gaff will be seized in the jaws of the infuriated sleeper, which may then be gaffed anywhere near the head and hauled from his lair. On being brought forth into the daylight, he opens his jaws to their full extent and grunts loudly, but seems a harmless, torpid creature enough, though it is prudent to keep clear of his tail, which 


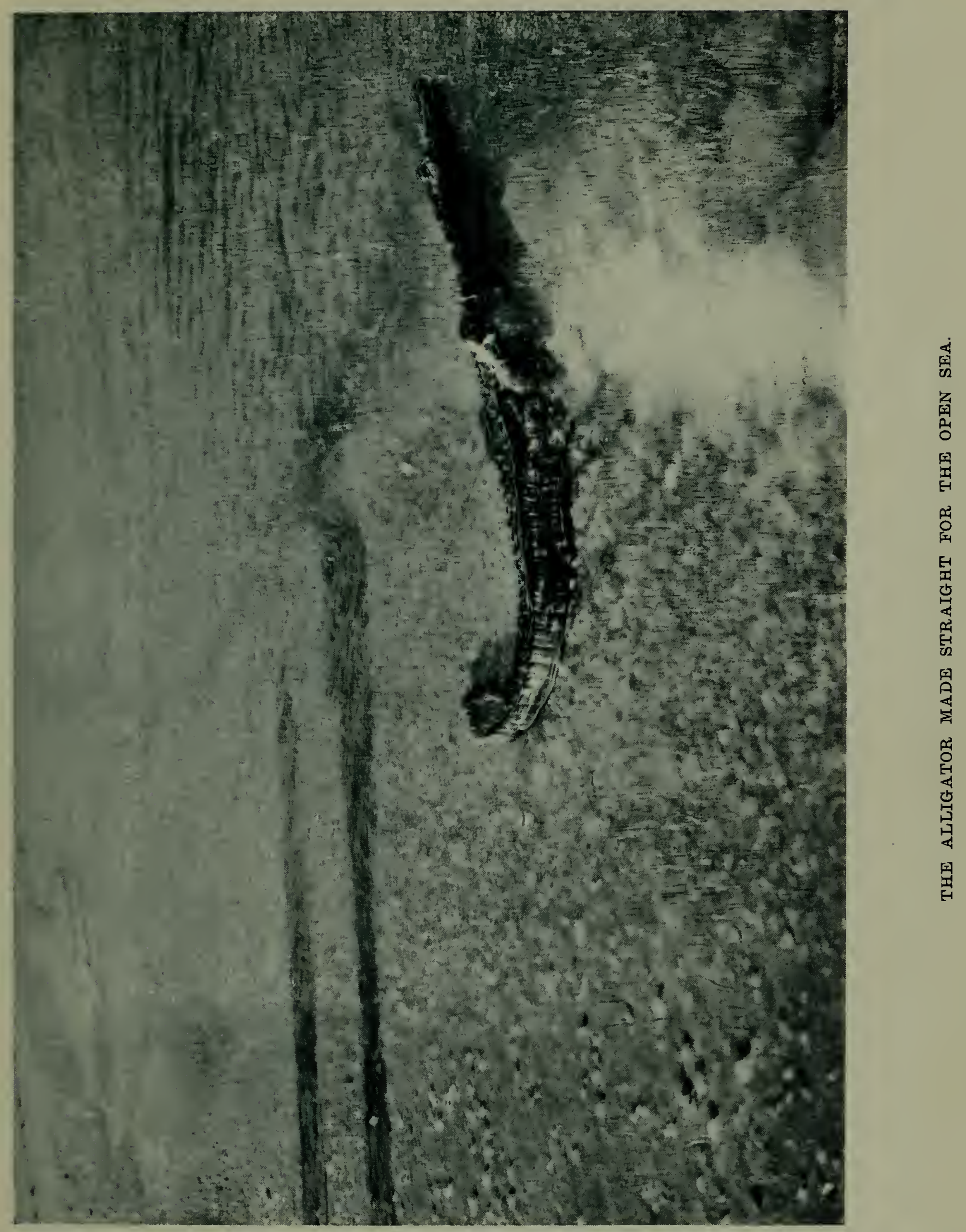





\section{Giant Fish of Florida}

can, with little apparent effort, whisk a man off his legs; and of the jaws, which then snap round unpleasantly near the other end.

It would be folly to class this pastime as sport, for it is merely a novel experience; but a somewhat more sporting method, where alligators are sufficiently plentiful, is to shoot them with a rifle at night. Professional hunters take only the underside of the skin, which is worth just twenty-five cents to them. There is one alligator story that every visitor to Boca Grand is sure to hear. A professional hunter was on one occasion engaged to find sport for a man who wanted an easy kill without adventuring his person among the parasites of the bush, and they returned with a dead alligator within half an hour. It afterwards transpired from an unknown source that the hunter had walked with his employer to a small pond a few hundred yards distant, and there made strange noises through his nose, and told the other to fire in a certain direction. The sportsman fired at quite another spot, being somewhat excited; but that made no difference, for the hunter rushed in knee-deep and dragged forth a fine dead alligator. There was no mark of any wound on its hide, but the man told us that it had been killed by the concussion. No one else said anything. Such recreation, however, is appropriate only to days on which sea-fishing is impracticable, and I now come to the main business of my notes, the capture of tarpon by the modern method of trolling. 

CHAPTER III

\section{How to Catch Tarpon}





\section{CHAPTER III \\ HOW TO CATCH TARPON}

HAVE I sufficiently introduced the tarpon itself ? I hope so. The fish shown in the frontispiece was caught in March, and was therefore in poor condition. They improve rapidly towards the end of April, and are heavy with spawn late in May. Strips of mullet-four cut from the white belly of each-are the orthodox bait for tarpon, yet an autopsy will reveal only an occasional fish, small crabs being by far the more usual food. When a tarpon is seen rising slowly, head and tail like a salmon, it may be regarded as on its way to the bottom to feed, its movements when routing among the rocks and weeds being notified by the string of bubbles that rise to the surface, much like the otter's chain.

In Boca Grand the tarpon is fished for close to the bottom, but elsewhere it is sometimes caught near the 


\section{Giant Fish of Florida}

surface. When actually rolling and playing on the waters the fish are rarely caught, and where they congregate in a strong tide and in shallows they are most difficult to hook-not more than one fish being on the average caught out of four or more strikes. When a hooked tarpon does not break water, a comparatively rare occurrence, he may be regarded as a heavy fish. Once the life is out of the tarpon, he is of little use, unless it be to furnish a trophy for exhibition to admiring friends at home, who may like to see what America can raise in the herring line. Yet probably this universal neglect is due to the abundance of other more excellent food-fish in those waters rather than to inherent unfitness, for its flesh is dark, firm, and meaty.

Not the least important factor in success is a good guide. These men are quite characters in their way, and never speak of their master as having caught or lost a fish: with them it is always "I did this or that," and in truth their experience and skill mean so very much that this egotism is not altogether unpardonable. They are for the most part civil and obliging e 1 ows, particularly the niggers, but there are, of course, exceptions, and these the sportsman should, for the public good, never hesitate to get rid of.

At the same time a little consideration is due to the guides themselves, and if they are worked all day, they should be allowed to rest at night. Quite apart from their carefully acquired knowledge, their duties are by no means light. 


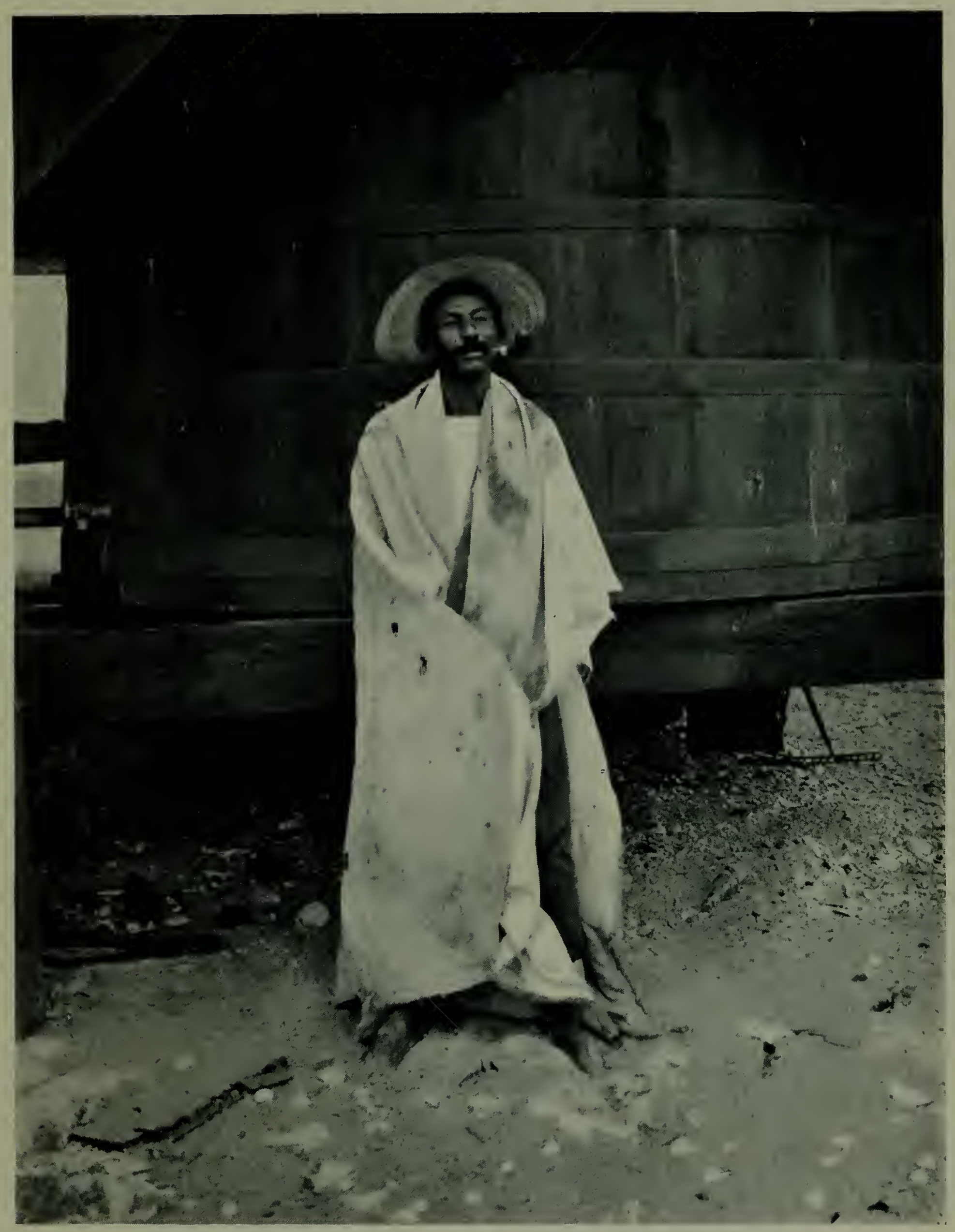

A TARPON GUIDE. 



\section{Giant Fish of Florida}

They have to be at their employers' beck and call at all hours of the day and night, and to help him get sport in a willing and efficient manner. During the fishing they have to exercise great care in manouvring the boat, so as to keep a tight line when it is impossible to reel in fast enough. They must also be always on the lookout for moving tarpon, and they must, above all, have an unfailing supply of fresh and well-cut baits. All said and done, the daily wage of less than a sovereign for the guide and boat is well earned.

Tarpon fishing has one feature unique in angling annals; it is a social gathering, and not by any means a solitary sport. Whether the undoubted charm of this distinction lies in the inherent gregariousness, often undiscovered, in the angler's bosom, or rather perhaps in the rare pleasure of seeing one's friends in all manner of difficulties, it is quite certain that tarpon fishing would be far less popular under other conditions. As it is, where the fish are seen on the move, there must every one go, and twenty or thirty boats will soon be clustered with no more than twenty yards between each.

An element of excitement is also imported by the continual apparition of great fish leaping high in the air, falling into boats and jeopardising life and limb, for it is a poor choice whether you will have ${ }^{5} 5 \mathrm{lb}$. of lively fish dropped on the top of your skull, or whether you will rather have it fair in the side, with the risk of being knocked overboard to the sharks. 


\section{Giant Fish of Florida}

There will no doubt be disparaging anglers who despair of tarpon fishing as a sport when they read my frank admission that it calls for little special knowledge beyond a useful husbanding of one's strength that can be acquired only with practice. At the same time, attention to the business in hand will often save many little inconveniences, such as getting your finger broken by the reel handle, or cut through by quick-running slack line.

In thus discounting the skill at present necessary to the killing of tarpon, I do not overlook the fact that this state of things will not in all probability continue indefinitely, since there are already signs that the tarpon may become both scarcer and better educated as the sport gains more adherents; nor is it other than probable that we do not yet know the best methods of catching this splendid fish. In Boca Grand Pass, for instance, we fish for tarpon with a strip of mullet used close to the bottom. In other places where the sport is followed they use a whole mullet near the surface. The probability is that we know no more of the life history and habits of the tarpon than our fathers knew of the salmon forty years ago. It is when greater art is called for in the capture of the scarcer and more wary fish that the more intelligent guides and sportsmen will inevitably score in a measure that, it must be confessed, is not always the reward of superior intelligence to-day.

As to season, the most agreeable time for tarpon fishing 


\section{Giant Fish of Florida}

is undoubtedly from the second week in April until the end of May, or as much longer, for the matter of that, as the mosquitoes are graciously pleased to let you bide in peace. Still-fishing, the old-fashioned method of angling, is practised under the lea of some islands only on days that do not permit of your getting out into the Pass. It bears considerable resemblance to some ways of sea-fishing at home, and consists in anchoring the boat, baiting and throwing out a gorge-hook, and then sitting down to wait for a bite. As often as not the bite never comes; as often as not, when it does, the fish proves to be a shore-haunting shark. 



\section{CHAPTER IV}

\section{A Lively Morning in the Pass}





\section{CHAPTER IV}

\section{A LIVELY MORNING IN THE PASS}

I WILL now endeavour to describe a typical morning's tarpon fishing in the Pass, and one such morning will, with varying results, be found much as another. The tides of Boca Grand are erratic, yet the guides must have an accurate knowledge of their vagaries, since on them depends the duration of the fishing-time. Only in slack water can tarpon be fished for with any comfort. The tide is, in fact, slacking, as four and twenty boats drift rapidly down through the Pass and out towards the Gulf, to row back close in shore and out of the current, and repeat the process.

Presently, as the tide is all but done, some one gets a strike; up comes a hundred-pounder a second or two later, eight feet in the air, shaking his head in fury until his gills rattle loudly, then, with a plainly audible grunt, shaking free 


\section{Giant Fish of Florida}

first the leads, then the bait, and finally the hook, all in about a second of time. This performance, however disturbing to the novice, barely attracts the notice of the old hand, for he is well accustomed to such treatment, and does not regard his hook as fast until the fish has made its second jump in vain. Still, the sight of the fish acts like a magnet on the other boats, which are now being rowed towards the favoured spot with all the strength of their guides, who well know that, like most of the herring tribe, tarpon feed in shoals.

And now I see that the lady-angler who yesterday landed four tarpon, is fast into another. $U p$ it comes and dashes straight into old "Orange Blossom's" boat, all but knocking the old man overboard, and wetting him through and leaving abundance of slime and scales on his coat; then, with a couple of kicks that break an oar and knock a crack in the boat, the tarpon flounders over the side. She must have lost it! No; it is still on, and there is no doubt about its being well hooked. The guide is now making frantic efforts to get his boat out of the press and towards the shore.

Meanwhile there have been two other strikes; one of the fish got away at the first jump, the other is playing the deuce all round, and now it is steering straight for "Dibbler's" boat. "Reel up!" yells the guide, but that is more than "Dibbler" can do, for is he not fast in his customary jewfish? About three of these great fish "Dibbler" hooks every day, and always in the same spot, losing them all with unfailing regularity through 



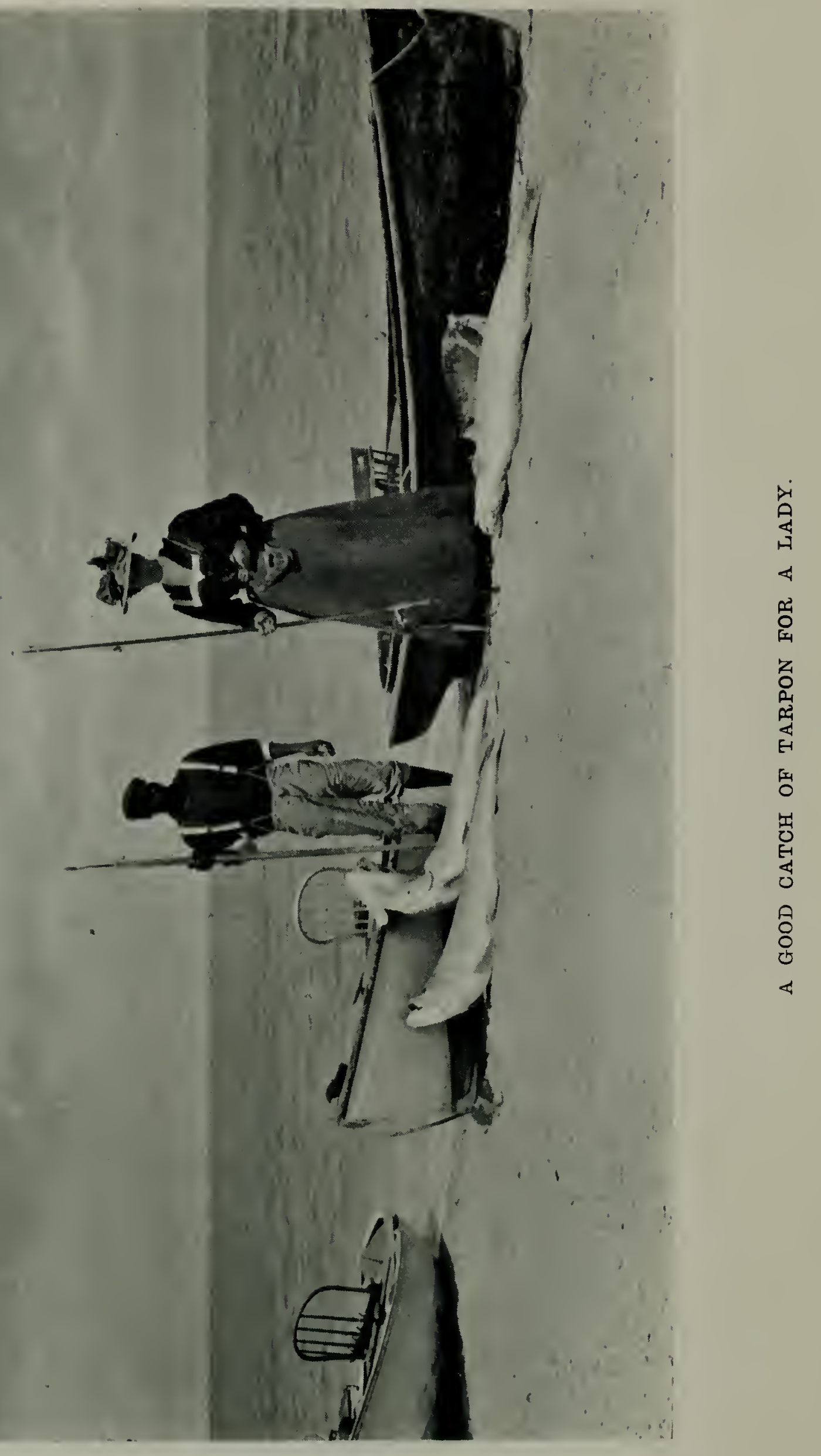




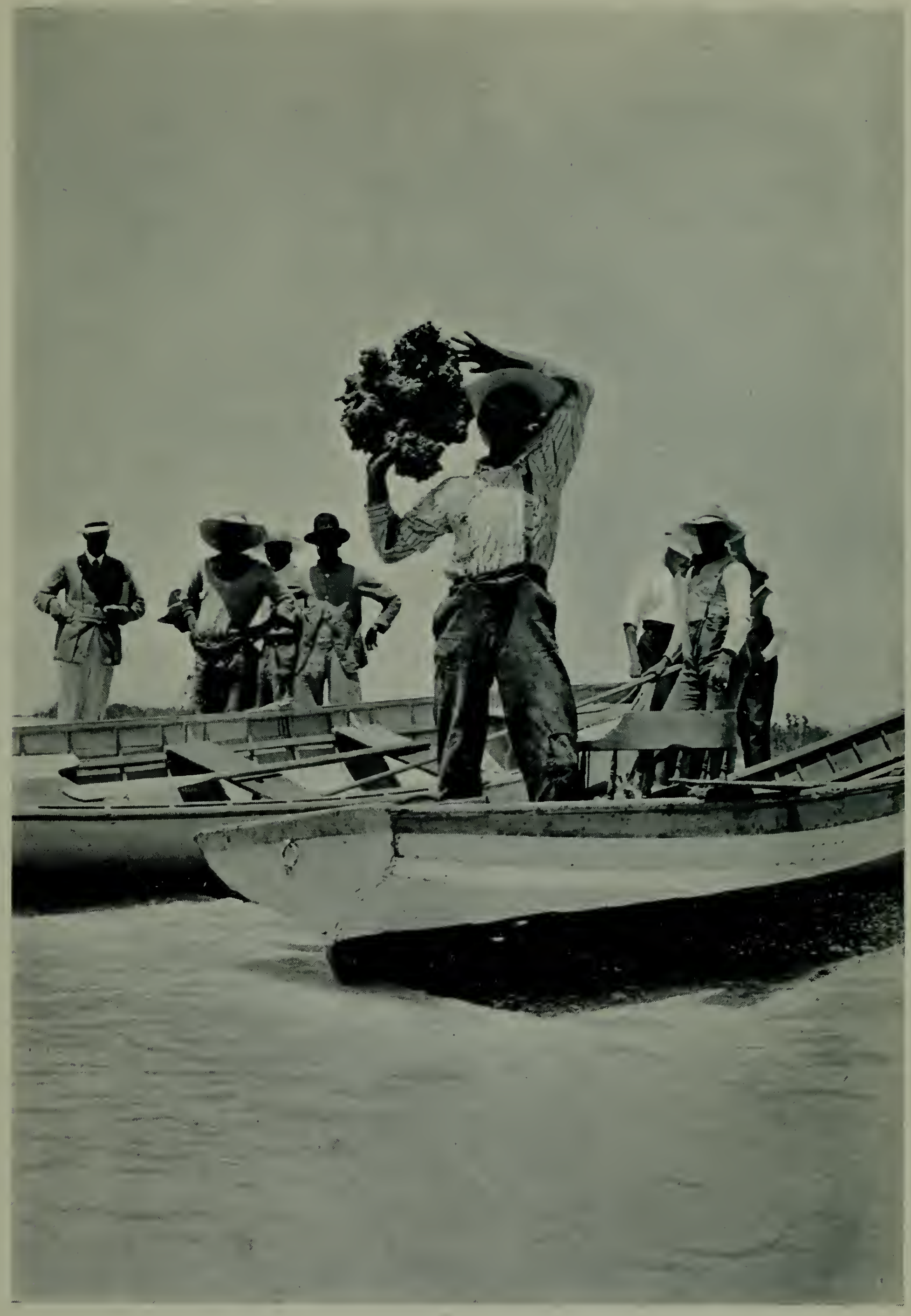

A HOOKED PIECE OF CORAL WHICH WAS MISTAKEN FOR A JEWFISH. 



\section{Giant Fish of Florida}

breakage. It is futile to try and persuade him that just at that spot the rock rises about fifteen feet higher than on the rest of the reef : nothing will induce him to keep clear of the rock, and he has his daily exciting struggles with his impassive and unmoved antagonists.

"Keep away!" he shouts, now "I am going to land this jewfish, whatever happens!" Yet who can keep a hooked tarpon clear of a given spot? Already the lady's tarpon has fouled poor " Dibbler's" line, and he, all unconscious, and with a radiant face that beams with anticipation, shouts out to us the inspiring intelligence that he is moving it at last, and will certainly land the record jewfish very shortly. Alas! the tarpon soon cuts through his frayed line, leaving him to float disconsolately onward and reel in, bemoaning the loss of yet another jewfish, and just as he was getting the best of it too!

Sometimes one of the lumps of coral is detached, and the novice, and on occasion even the old hand, will play it for the best part of an hour, for it may easily be mistaken for a jewfish, a sulky monster that may weigh up to $300 \mathrm{lb}$. The deceptive effect is heightened by the drifting of the boat, and altogether there is much excuse for the error.

It is wonderful, too, how deceptive some of the bolder biting fishes are. I recollect on one occasion seeing a novice strike, as he thought, a tarpon, throw himself backwards and play it as he supposed right; his guide, who also 


\section{Giant Fish of Florida}

seemed to think it was a tarpon, manœuvred in the orthodox way, and presently a pound-grouper flew into the boat!

There have now been some seven strikes, with only two tarpon landed, and sport is somewhat slack. A fair angler carelessly trailing her bait over the side is suddenly startled by the magnificent leap of a thirty-pound kingfish, a mighty mackerel, which all but wrenches the rod from her hands. Away it dashes, taking out line at an appalling pace, foul-hooked in the eye, but unable to free itself, and at last duly brought to gaff. What a handsome fish! Particularly noticeable are the knife-edged, conical teeth, that can cut baits just below the hook as with scissors, and the small proportion of its fin to its swimming power.

The kingfish is one of the swiftest swimmers in those seas, and the Spaniards recognise this by calling it "cavalla," or the horse. I have shown two figures of kingfish, the one chasing a skipjack, its favourite food, below the surface, the other leaping in the air and throwing up a newly-hunted skipjack, an almost invariable habit. Indeed, a kingfish breaking water always appears to have a skipjack in readiness to throw up, and this, its next meal, accompanies it for about a third of its flight. Although the skipjack appears to be knocked out of the water by the kingfish, and sometimes shows bleeding rents in its sides, it may be that the leap is a voluntary one to avoid capture, for it is 



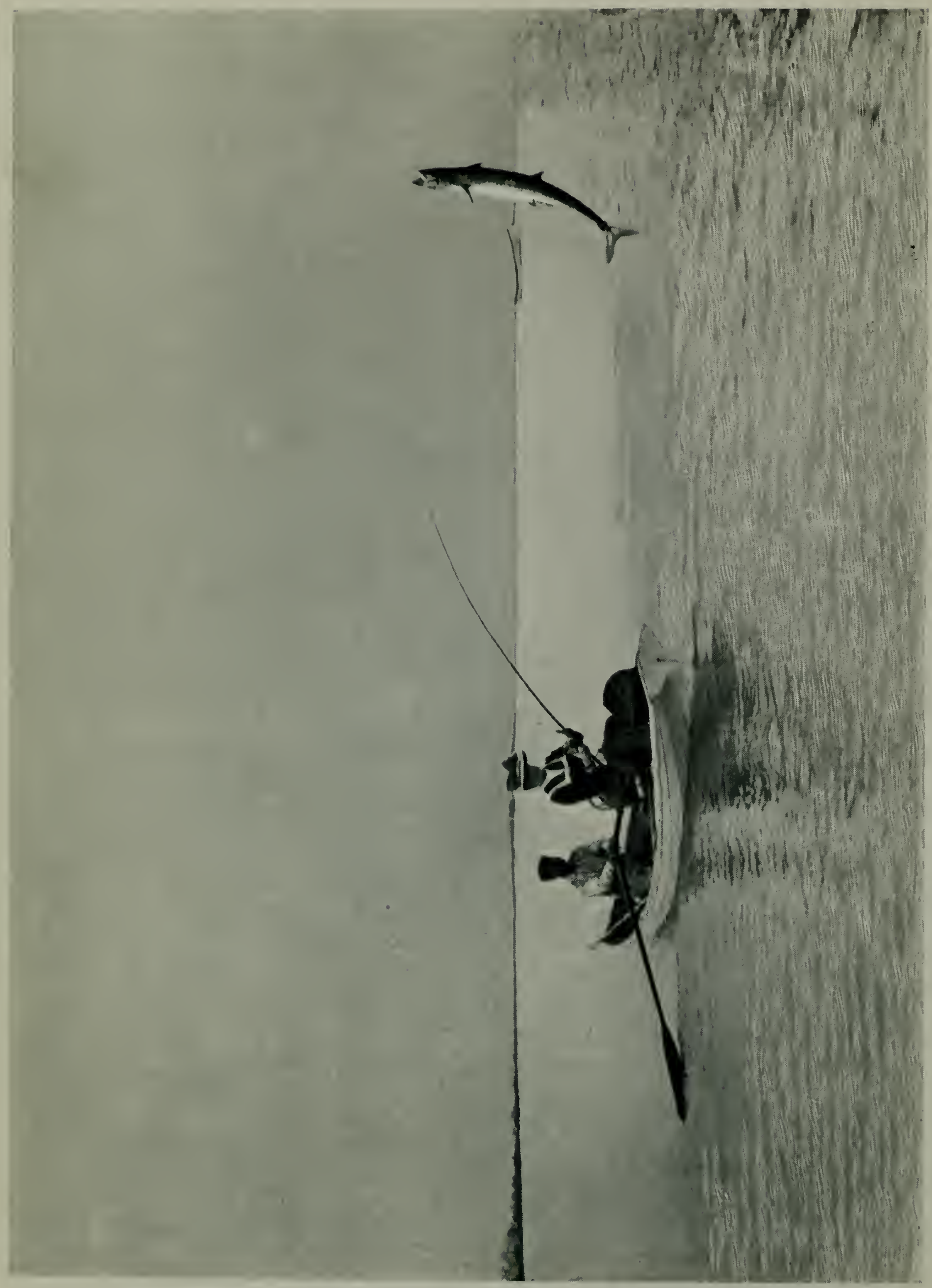

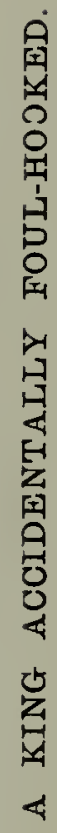




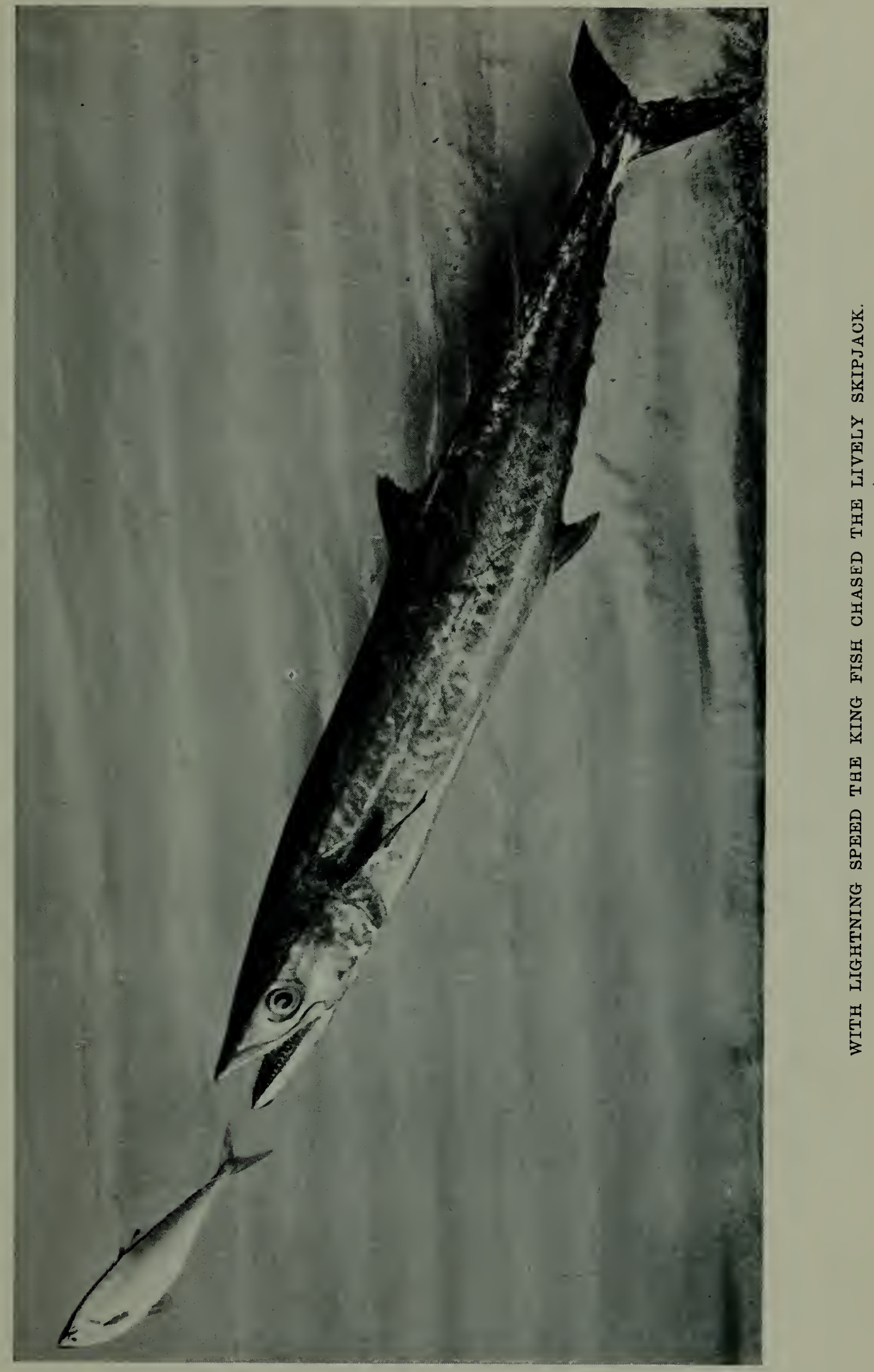





\section{Giant Fish of Florida}

difficult to imagine the object of the kingfish in throwing its prey into the air. These skipjacks often skip into boats, and exceedingly beautiful little fish they are, with the steely blue sheen on their burnished silver coats, and their amber fins and sharply-forked tail. The damaged tail-fin of the swimming kingfish figured opposite struck me the moment I caught it, and I came to the conclusion at the time that the tail-fin had been bitten by a prowling shark that the kingfish was, thanks to its lightning speed, able to baulk of a more substantial meal. Of the sharks that infest this coast I shall have something to say later on. They are numerous and ravenous, and spare nothing, great or small.

And now the tarpon are biting again. There are two, three, four strikes; three fish have jumped, two are fairly hooked. The excitement grows.

" $\mathrm{Hi}$, you, sir! reel up there. Can't you see you have fouled that lady's line? Cut your line-tell you you have no fish on at all-just cut your line!"

"Pull like hell!" shouts some one to his guide, as his tarpon rushes in towards him.

"Pick up that chair, Bill," cries the guide, a minute later. "My gent's fallen out-got to tow him ashore. There goes a rod broken at the butt."

"Lend us an oar, Sam ; mine's smashed."

"Come and get it yourself," sings out the courteous Sam. "Can't ; got a fish on." 


\section{Giant Fish of Florida}

"Look out! There's a shark after your tarpon. Where's your gun?"

"Now, then, you there ; where are you shooting?"

And so on, and so on. Six mad tarpon, six mad fishers, six mad guides, and six quite unmanageable boats dashing about in confusion among near a score of others. This it is that makes tarpon fishing so fascinating once you get the true spirit of the thing. In those two hours that we have been out just nineteen fish were landed out of fifty or sixty strikes, and more than one boat never got a touch.

As soon as the tide runs too strong boat after boat is pulled ashore, and every one seeks a shady nook for luncheon, generally under the lighthouse. Here in the cool we munch our sandwiches and talk tarpon, every other subject being tabooed at Boca Grand. And how wonderfully has that big fish of yesterday increased in the night! It was really a fine fish, scaling, as a matter of fact, I7I lb., and needed no editing. Yet the man who weighed it called $\mathrm{I} 8 \mathrm{I} \mathrm{lb}$. The fortunate angler added a matter of Io $1 \mathrm{~b}$. for loss of weight in transport to the scales. This somewhat generous allowance for wear and tear brought its already respectable weight up to Igr lb. That was last night. To-day he speaks of it as "close on $200 \mathrm{lb}$." " and we can infer what that will mean as soon as he gets back home.

Then, as to its measurements, he left it hanging out last night, and measured it alone this morning. It hung by one 

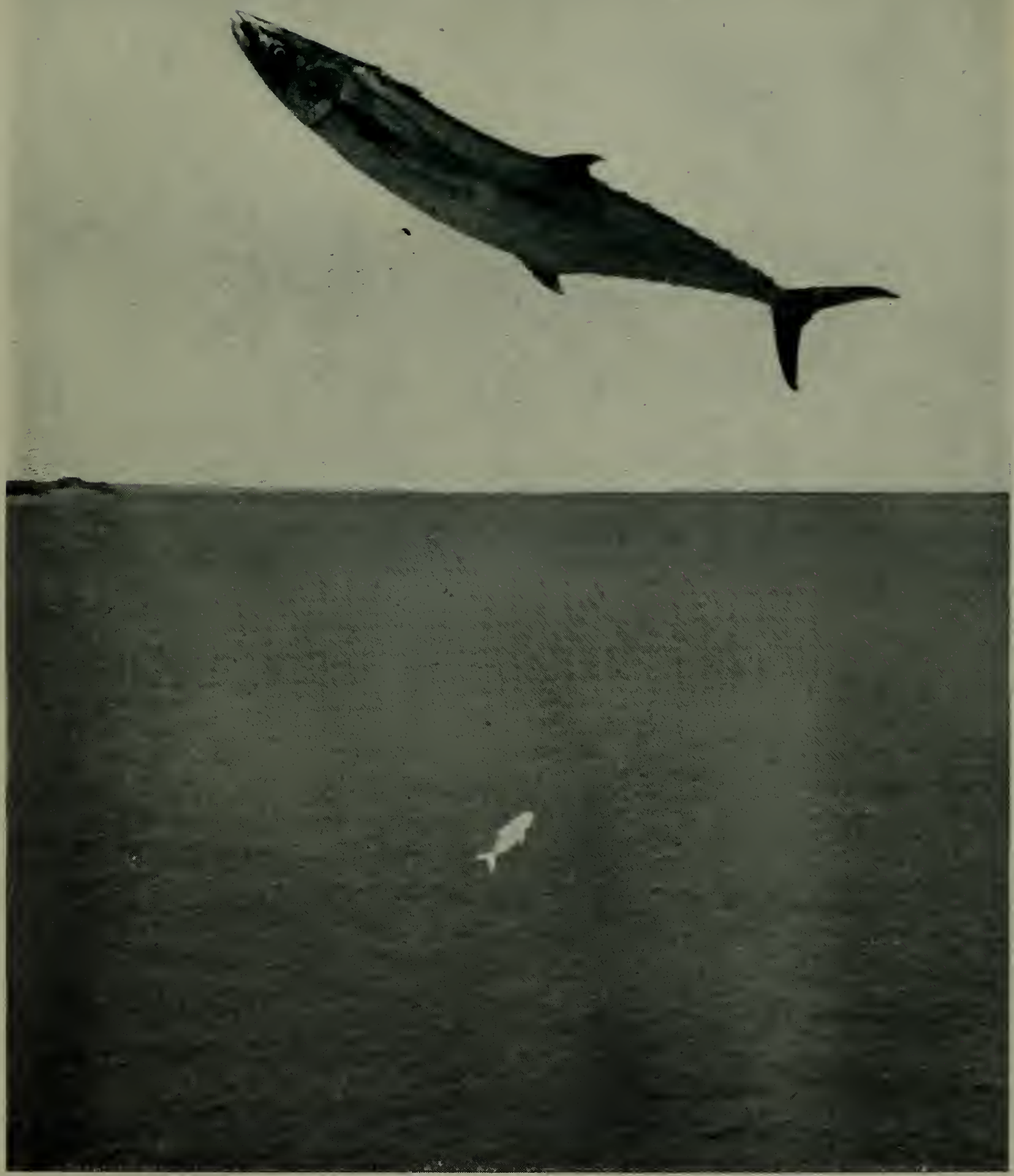

THE KING FISH LEAPT SOME 20 FEET INTO THE AIR, AND UP WITH HIM CAME A SKIPJACK DEEPLY GASHED ALONG THE SIDE. 



\section{Giant Fish of Florida}

jaw, and its own weight must have stretched it by at least three inches. He is not, however, content with measuring it with the mouth open; he must needs add another four inches "for luck." This is only a fair example of the manufacture of long and heavy fish, and a little study of such cases will go far to explain not merely the extraordinary shrinkage in the hands, of the taxidermist, but also the otherwise incomprehensible fact of some sportsmen getting so large a percentage of the heavy fish, while others score only the average. 

CHAPTER V

\section{Ladies Who Love the Sport}





\section{CHAPTER V}

\section{LADIES WHO LOVE THE SPORT}

THERE are generally some ladies in the company, indeed the gentler sex seems to have taken to tarpon fishing to an extent quite unforeseen when first men introduced the sport. It is wonderful, too, how ladies manage to hold on to these mighty fish, and to husband their strength, the department in which, in their excitement, they might reasonably be expected to fail. I have already mentioned the feat of the lady who killed her four tarpon in one morning. Considering that these fish weighed close on roo $1 \mathrm{~b}$. apiece, this was no mean achievement. This same woman, while beaching one of her first heavy fish early in the season, fell backwards over a few straws. She was too exhausted to stand upright again for some moments, but so excited was her imagination that she was firmly persuaded, until 


\section{Giant Fish of Florida}

convinced by the evidence of her own eyes, that she had fallen over a $\log$

There were many other successful lady anglers. One of these caught and landed a jewfish scaling I37 lb., and this must have called for all her strength, for these jewfish have enormous power of resistance so long as they sulk at the bottom, which they do as if they were rocks. I have watched a man fighting with a $35^{\circ}-1 \mathrm{~b}$. jewfish, which he eventually succeeded in killing, though not without a severe tussle, which taxed his patience and his tackle in no small degree.

For a long time we thought he was playing a rock, after the manner dear to "Dibbler," so little did the object in which the hook was fast seem to yield to his persuasions, and it was only the fact of his being too old a hand to be taken in by any such makebelieve that convinced us that big game was really in question. For a good twenty minutes hard pulling he cannot have moved that jewfish through more than fourteen feet of water, and all his labour would seem to be undone next moment, for the monster simply sinks to the bottom again and is doubtless trying to cut his line against some sharp coral edge. Yet his skill and patience have not in fact been thrown away, for the great fish is tiring. The next steady strain brings it appreciably nearer to the surface, and at last, after a giant's contest lasting fully two hours, the three hundred and odd pounds of fish float blown and helpless on the top of the water, the vanquished monster looking more like a barrel than a fish. 



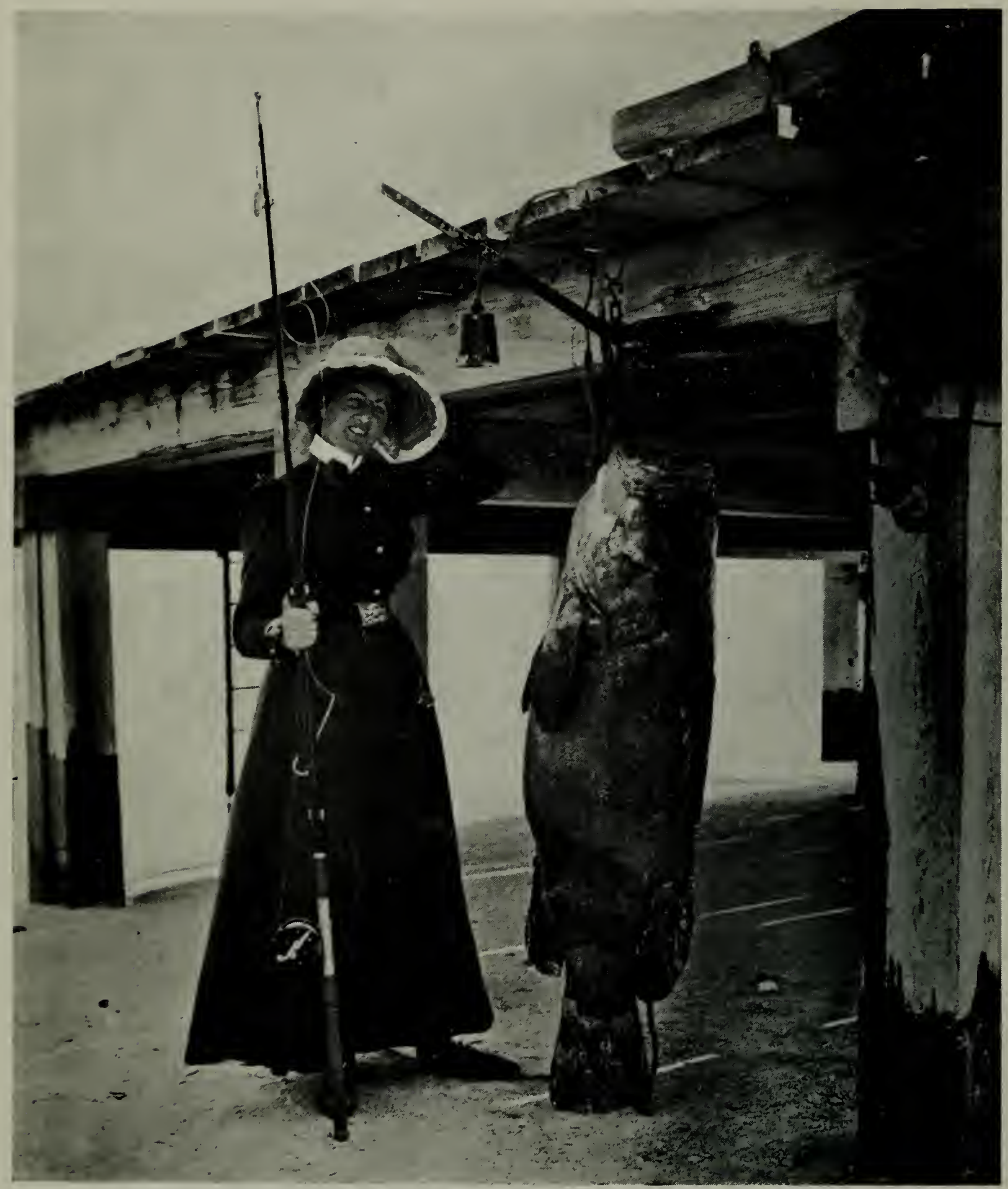

A BIG JEWFISH FOR A WOMAN TO LAND. 


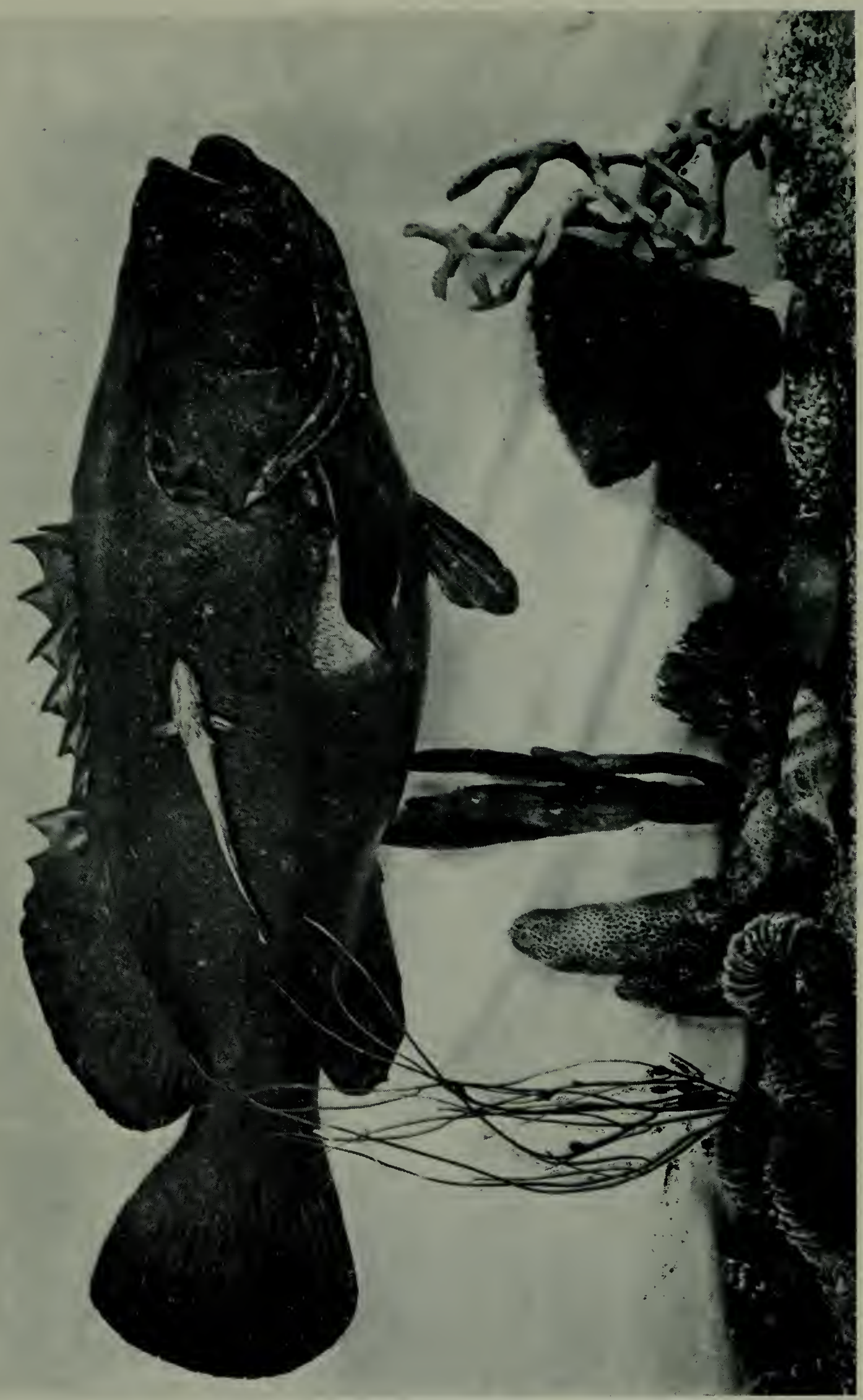

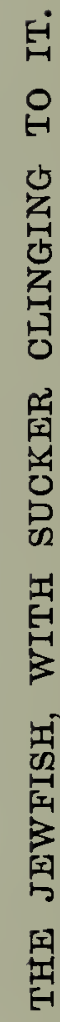





\section{Giant Fish of Florida}

Like most ground-hugging species, the jewfish, once brought to the top, is inflated and helpless. His one hope is in the razor-edges of the coral, and well he knows how to turn these, where available, to account. If he is caught, it is because he has inadvertently wandered far from his natural defences, and cannot risk a sudden haul from above by an attempt to regain them. A ponderous perch-like fish, he is known in many southern and sub-tropical seas, and is a favourite object of sport, like his ally, the grouper, all round the Australian coasts.

It is just possible, of course, to reckon too securely on this helplessness of jewfish when hauled to the surface, for an occasional captive may put forth exceptional efforts to regain its liberty. Thus, I recollect a case in which one of $300 \mathrm{lb}$. was lost by a lady through too great reliance on this usual collapse, for the fish was made fast by the line close alongside the boat, and was being towed ashore, when it made a sudden dash for freedom and went down like a stone.

Like most of the other great fish of those waters, the jewfish is troubled with suckers, and in the photograph facing this page may be seen a sucker of about I lb. adhering to the side of a 400-1b. jewfish. So close do these uninvited guests cling by means of their sucking apparatus on the head, that only a quick leap (which the jewfish, by the way, cannot manage) and a sudden twist in the air dislodges them. I have seen sharks leap out of water and throw them off in showers. The only 


\section{Giant Fish of Florida}

thing that will tempt a sucker from its comfortable position is a small and suitable bait dangled near it. Thus lured, it will frequently swim away from its host, and allow itself to be caught.

The scales of the jewfish are somewhat curiously formed, and those of sufficiently active imagination profess to see in the centre of each an accurate and unmistakable full length portrait of the Virgin Mary. Many, however, will, I venture to predict, look for this in vain.

Before quitting the subject of the many successes achieved by women on those hunting grounds, I may mention one in which an enormous whip ray was foul-hooked, and the lady obligingly stood on her victim that the camera might do its share. On the whole, fishing in Florida seas may be said to offer thrilling sport to such ladies as are venturesome enough to give it a trial. There is just that spice of danger which sportswomen never resent, without the need of prolonged roughing it, that tries them far more than sudden calls on their endurance. As long experience and angling skill are not required, at any rate at present, a lady has on her first outing as good a chance as any one of hooking the record fish of the season, tarpon, jewfish, or shark, as the case may be ; nor is the ordinary work of tarpon fishing, though beyond doubt arduous, such as to alarm any woman of average aptitude for outdoor sport. When you have fairly hooked your tarpon, you sit comfortably back in the armchair, your rod resting in a socket screwed on the thwart or suspended round the waist, and thus you pit your 



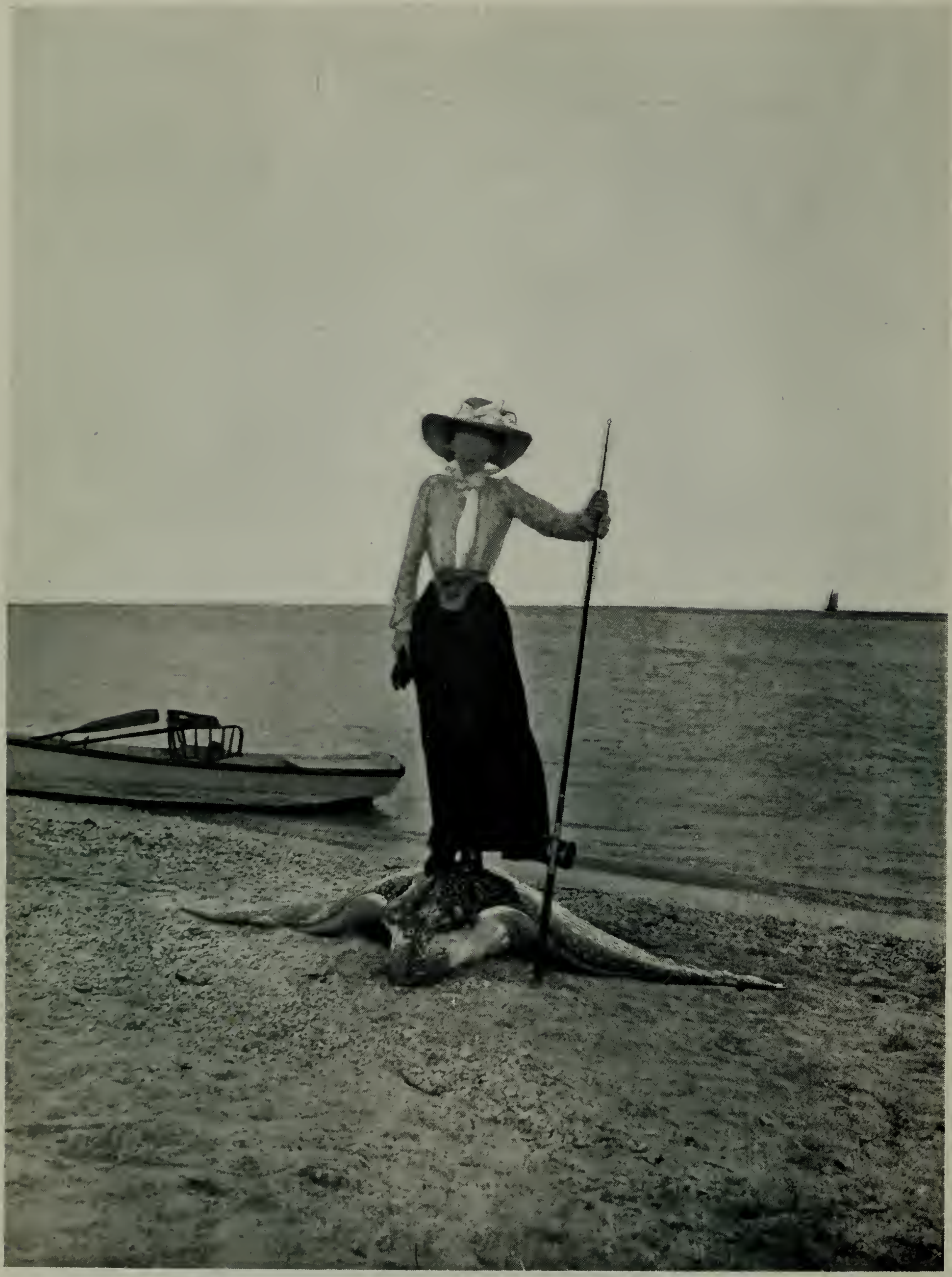

THE VANQUISHED WHIP RAY. 


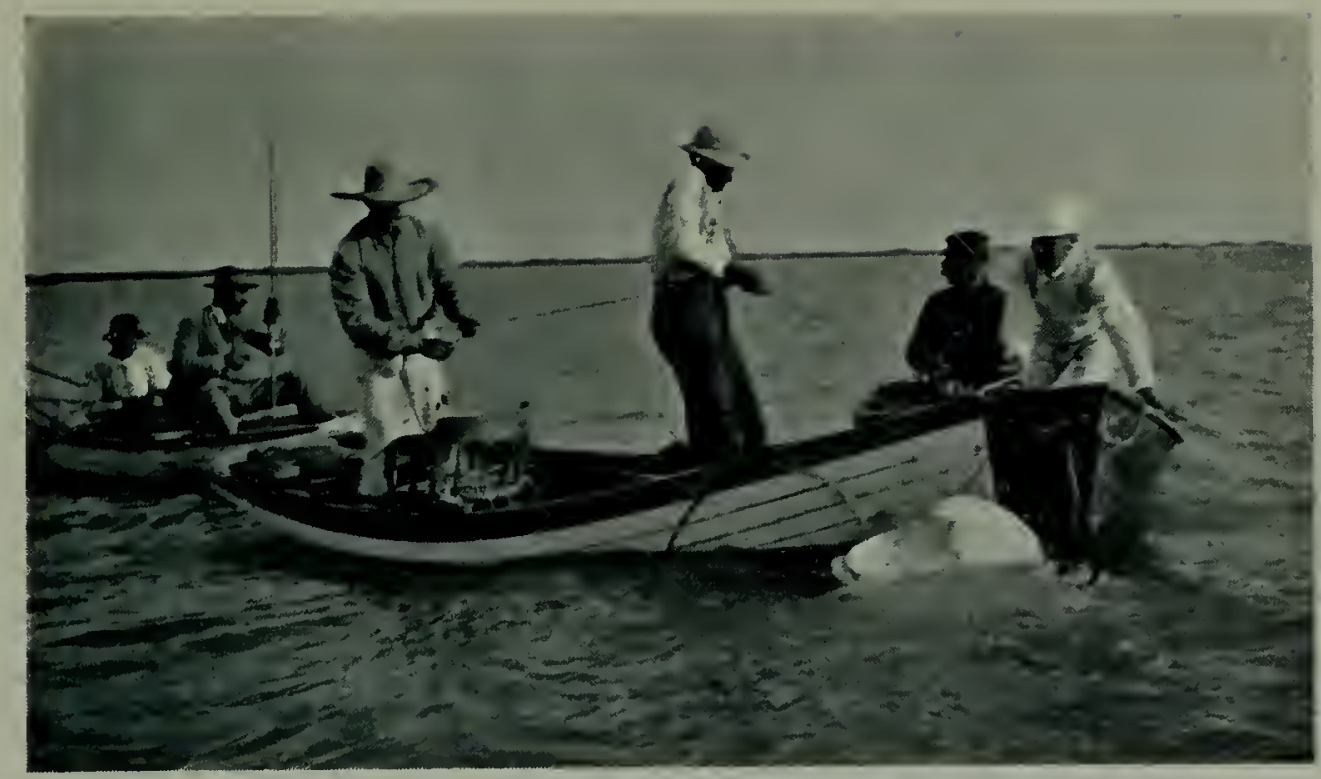

THE WHIP RAY FIRMLY HARPOONED TURNED HELPLESSLY ON ITS BACK.

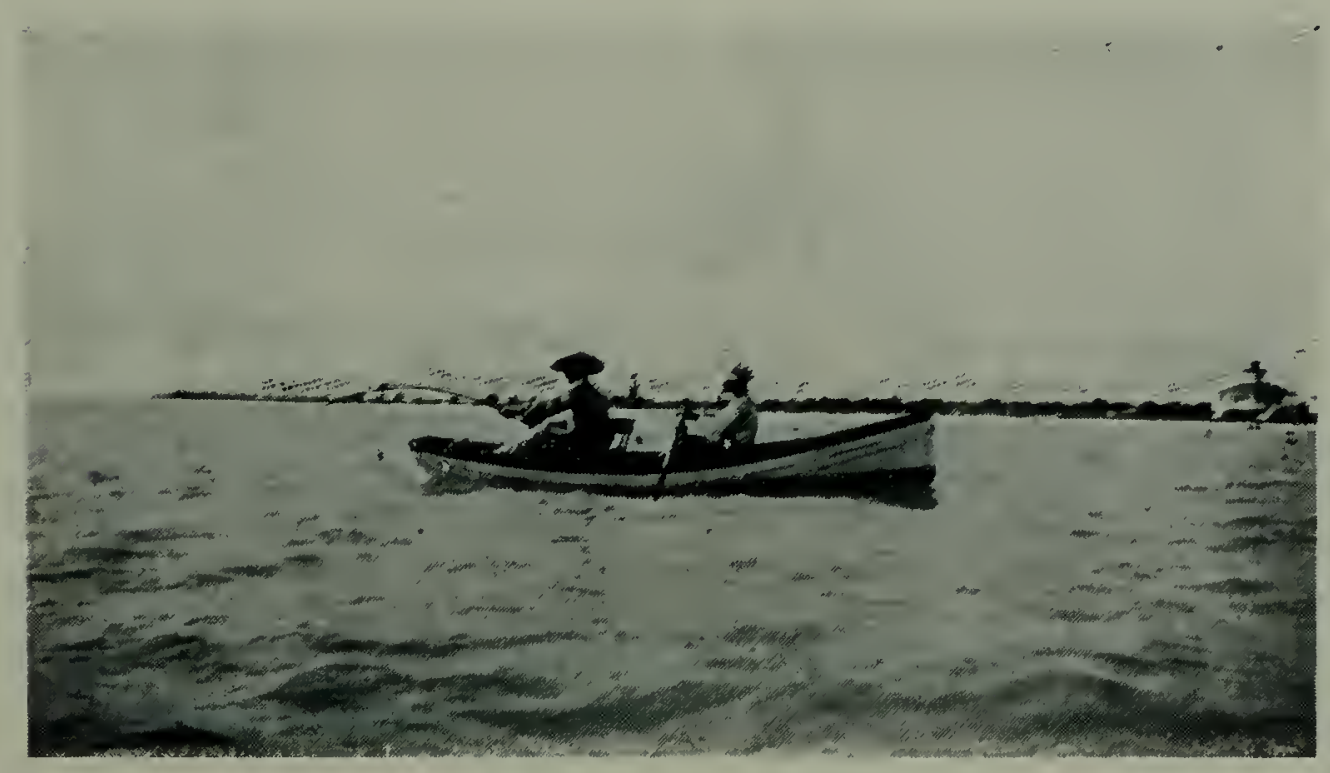

STEADILY THE HOOKED TARPON FOLLOWED THE BOAT TOWARDS SHORE.

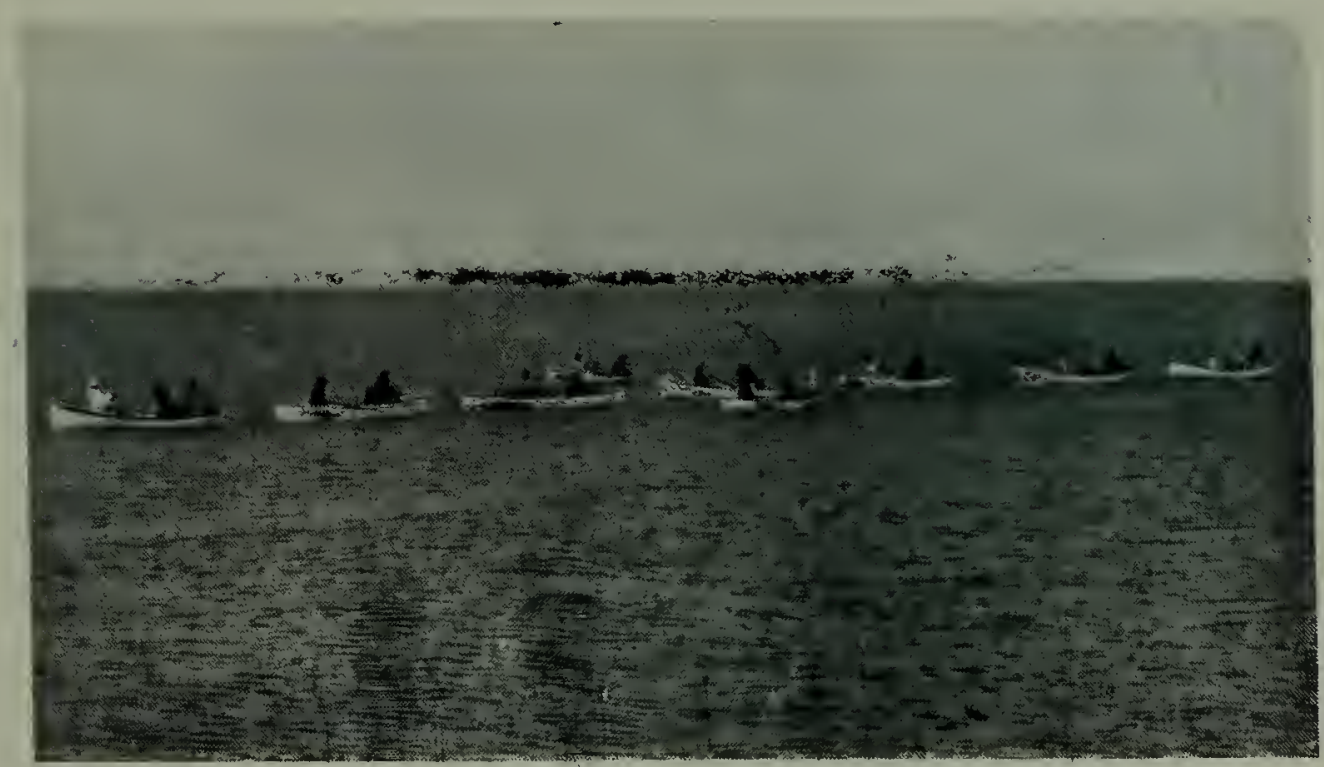
RAY. 



\section{Giant Fish of Florida}

strength against that of the fish. Your reel carries 200 yards of line, but it is rarely that half of that length is required. Most tarpon fishers bring their fish to the gaff from the boat, but it is far more sportsmanlike to beach them, as they need not then be destroyed.

When this lady foul-hooked the whip ray, it towed her boat about for quite half an hour. She then got rather tired and handed her rod to her husband, who, in the course of another hour's hard fight, could do no more than raise the brute to the top of the water fully thirty yards away from his boat. He then sent along to the man with the harpoon to help him, and next time the ray came to the surface the harpooner had it fast, and it was triumphantly towed ashore by a remarkable procession of boats. Its estimated weight was $500 \mathrm{lb}$, and this I should regard as not far wide of the mark. 



\section{CHAPTER VI}

\section{Enormous Rays, or Devil-Fish}





\section{CHAPTER VI}

ENORMOUS RAYS, OR DEVIL-FISH

RAYS, which are somewhat closely related to the sharks, though so different to the casual observer, are characteristic of all seas, but especially perhaps of the tropical waters of America, where some of them attain to enormous weight. The stingrays, of which the one depicted in this volume is a variety, armed with formidable serrated spikes at the base of the tail, are in some cases fearsome creatures, while many of the family are provided with the means of numbing their victims with an electric discharge. The whip ray, however, though carrying spikes above the tail, is a harmless and indeed beautiful creature. At the same time, its frantic leaps when driven wild by the suckers that adhere to its disc are sufficiently alarming to those unaccustomed to its ways.

To see a kite-shaped creature with a long and whip-like 


\section{Giant Fish of Florida}

tail leaping high in the air, then merely touching the water again like a ricocheting shell and again soaring aloft, a series of such leaps taking it quite a hundred yards over the surface, is, to say the least of it, a novel spectacle to those just out from Europe, the seas of which do not afford these apparitions. It is as if the monster fish were suddenly tenanted by the wandering spirit of a defunct kangaroo, and when it is added that its aerial leaps often bring it quite close to the boatsthough I do not remember hearing of a single case in which it actually jumped into one-it will be seen that there is some excuse for the occasional signs of alarm evoked by its sudden appearance. The splash with which it regains the water can, on still days, be heard quite a mile away.

The swimming action of these great rays is very beautiful, displaying all the graceful undulating movements so characteristic of the shark tribe, which go so far towards mitigating the repulsive appearance of some of them. There is always this striking contrast between the live and dead shark; the one, though endowed with instincts that can never commend it to our goodwill, is yet a very lithe and graceful robber; the other, deprived of all life and movement, shows only the vices with none of the redeeming beauty.

A more characteristic pose of the rays, however, is that of lying motionless, or, at most, with its disc slightly undulating with respiration, on the sand just under water. Sometimes, indeed, they are found lying a yard or so above low-water mark in pits 


\section{Giant Fish of Florida}

of their own making, and it is in such positions that they may be particularly dangerous, through no fault of their own, to the too eager surf-fisherman who wades bare-footed in the muddy water, careless of such risks. The whip rays seem of wide distribution under a variety of names, and a striped species has been taken on the Irish coasts. It would be difficult to know what use the delicate tail-usually stripped bare of its skin an inch from the tip-can be to this fish. The armament of spikes at the base can be erected at will, and the fish is able to bend up its back, much after the fashion of the scorpion, so as to bring them to bear on enemies attacking it in front. Each spike is serrated, its innumerable small points setting inwards, and the whole is enveloped in a skin so thin as to be ruptured by the mere act of withdrawing it from some body into which the fearful weapon has been thrust. My own impression is that portions of this skin remain in the wound, and set up that local poisoning that gives to such an act of aggression the popular name of "stinging."

There are even larger rays on that coast than the whip ray. The giant ray, for instance, is one of the largest of existing fishes, and specimens have been captured measuring as much as twenty feet across the "wings." Indeed, the Spanish and half-caste pearl divers call this ghoulish monster the "blanket," from a fixed belief (though no one can have survived to tell the tale) that it envelops its victims as in a blanket, and then devours them at leisure. This sobriquet 


\section{Giant Fish of Florida}

survives in the adopted scientific name of Manta. It appears to me that such a diet is against all probability, if we may judge by the food of most of the order, but these men are firmly convinced that the giant ray, or, as it is also not inappropriately called, devil-fish, is an inveterate enemy to man, and they at least earn the right to an opinion on dangers to which they alone are constantly exposed.

The proper way to capture these creatures, if any one cares about an occasional hour's excitement, is with the harpoon. As for catching them on the rod, it is only done by foul hooking, and it merely strains the arms and tackle in what cannot be described as a very good cause. Harpooning, however, may be really exciting, and I will try to describe such an adventure to the best of my recollection.

You take the harpoon and get your guide to row you along the shore northwards. Standing in the bows, behind the neatly coiled harpoon line, you keep a sharp lookout for game, and very soon you see a mighty disc lying on the sand at no great depth. Poising the harpoon in the air, you let drive at the object of your desires; it vanishes in a trailing cloud of sand, and you have an opportunity of seeing how poor a shot you made by insufficient allowance for refraction, which, of course, distorts the size, shape, and position of objects under water; and, as you assure yourself that in this case the harpoon went a good five feet ahead of the fish, you resolve to study the position of the next more accurately. 


\section{Giant Fish of Florida}

Look out! Here is a long, dark object coming straight at you. It is a shark. Let him have it right in the neck. That is better. The harpoon has struck this time.' Habet! Only the weapon has entered near the tail, not within four feet of the spot you thought to reach. You have to keep the rope close to the bow, or the brute may capsize you. But the harpoon has come away, and you coil the rope for the next comer. There is a sting ray right under your boat. No calculation necessary this time. You strike it fair in the centre. Be careful how you handle it, for should it get its spike into you, you will remember the wrenching out of the barbs.

All ready again! See that dark patch a hundred yards ahead! It is a whip ray, weighing perhaps $400 \mathrm{lb}$. How gracefully it flies beneath the water! You take careful note of its bearings, and reckon that it lies about seven feet deep and perhaps seventeen feet ahead. This means that the centre of the fish is some nine feet nearer to you than appears to be the case. Good! You threw too far again, but the ray is struck near the head, and you will get some sport anyhow.

The infuriated fish tows the boat in all directions. It is too heavy to haul in, and must be got ashore. This is not very difficult, for you let it run free when heading in that direction, and check it when making a move for deeper water. At last it is beached. There is no occasion to cut out the harpoon, for all you need do is to thrust in your finger and press up the barb on either side, and it comes away at once. 


\section{Giant Fish of Florida}

As a trophy, the back of this ray, with its black ground and small white rings within larger ones, characteristic of old fish, makes a handsome table cover. The tail is about six feet in length, and less in thickness than a cedar pencil, and at its base are three or four barbed spears. It feeds entirely on crustacea, never taking a fish bait, and is caught only by foul hooking. In the roof of the whip ray's mouth will be seen a series of processes like corrugated grinding stones, and there is a corresponding series on the lower jaw. It is between these that the shell fish are thoroughly triturated. I have somewhere read that the male rays have sharper teeth and no grinding arrangement, but I am not sufficiently acquainted with the sex distinctions to bear this out. 


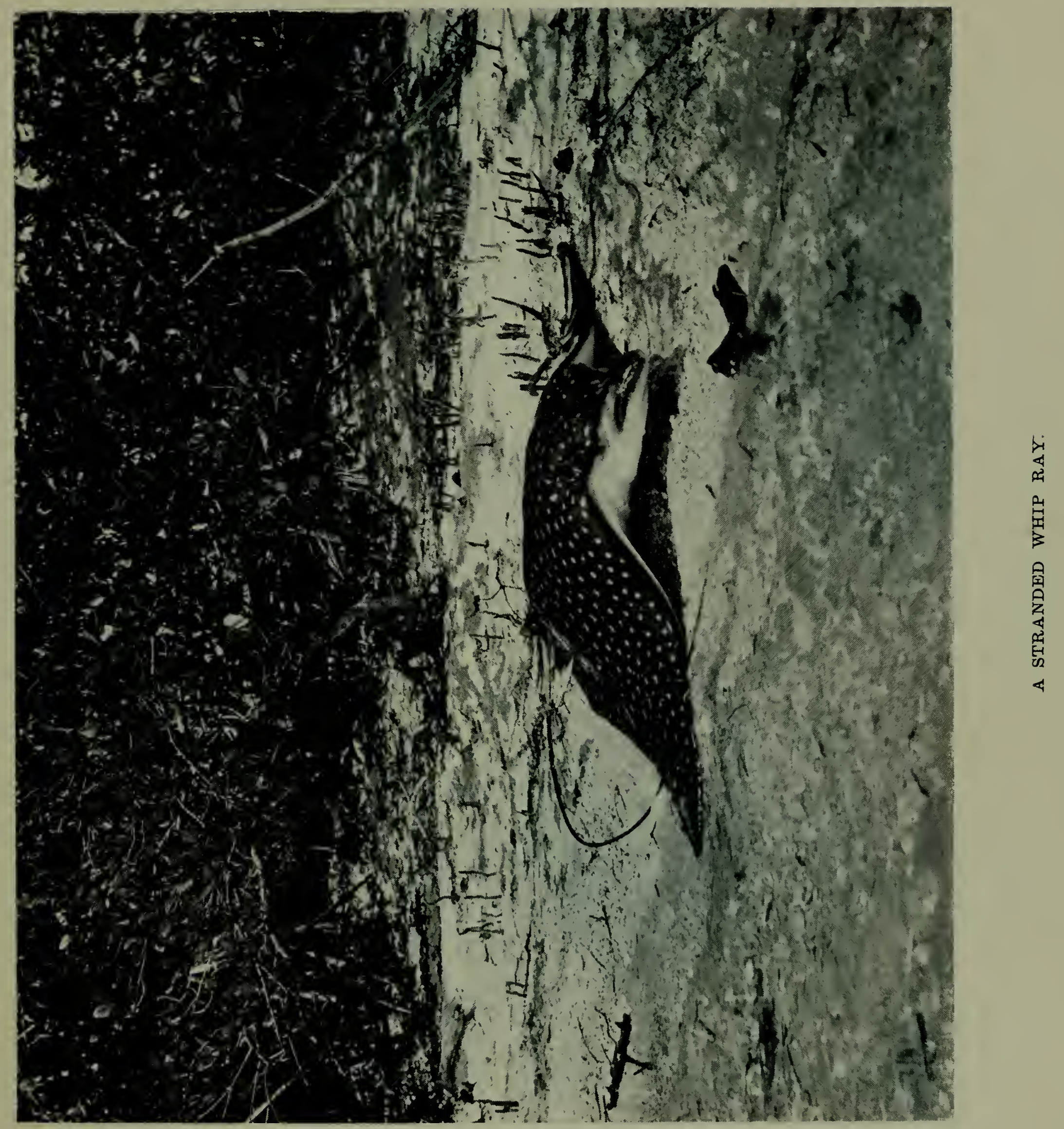





\section{CHAPTER VII}

\section{Harpooning a Monster}





\section{CHAPTER VII}

\section{HARPOONING A MONSTER}

I REMEMBER another exciting adventure, which resulted in the capture of a giant ray, weighing many hundred pounds. The wind had just gone to the south after many days of cold northers, and, whereas it would require several days of such wind to bring the tarpon back to a feeding humour, this first breath from the south was sufficient to stir up a long line of foam and slush that means food to the devilfish. Twenty feet and upwards across these monsters may measure, and they have been taken weighing over $4,000 \mathrm{lb}$. In the corners of the mouth, which gapes like a letter-box, are coiled fans that are used in waving the food into the throat. Three of these devil-fish we saw on the day in question, coming along and raising breakers as if they were steam-propelled rafts. With the tips of their great wings 


\section{Giant Fish of Florida}

occasionally showing, and their huge shining. black backs continually appearing above the surface, they looked very terrible.

In full pursuit was the man with the harpoon, who had been waiting such a chance for weeks. And now, as we can plainly see, he is close to this moving line of flesh. Whiz goes the harpoon, hurled by a strong and practised arm; not only the metal head, but also the shaft is deeply buried in that three-feet slab of flesh, and the maddened monster bounds off with lightning speed. The next moment the man changes places with his guide, no easy proceeding in a slender $\mathbf{I}_{4} \mathbf{f t}$. craft, but it is necessary that he should do.so, for he killed a devil-fish alone not a month since, and the skin has not yet grown again on his raw hands. Ere the boat has got properly under way a loose bight of rope catches the guide round the leg, and flings him into the gunwale ; there is plenty of way on now, and a dangerous list into the bargain as the bow dips under water. The man rushes, knife in hand, to his guide's assistance, but the latter succeeds with great dexterity in freeing himself from the coils, and there is no need to cut loose.

And now the pace grows fast and furious. Eighty feet of line are out, waves are flying from the bow, and the boat speeds so that no launch in Florida could catch her. The great fish is close to the bottom, and suddenly shifts its course. This manœuvre is like to cost it dear, for it enables six 




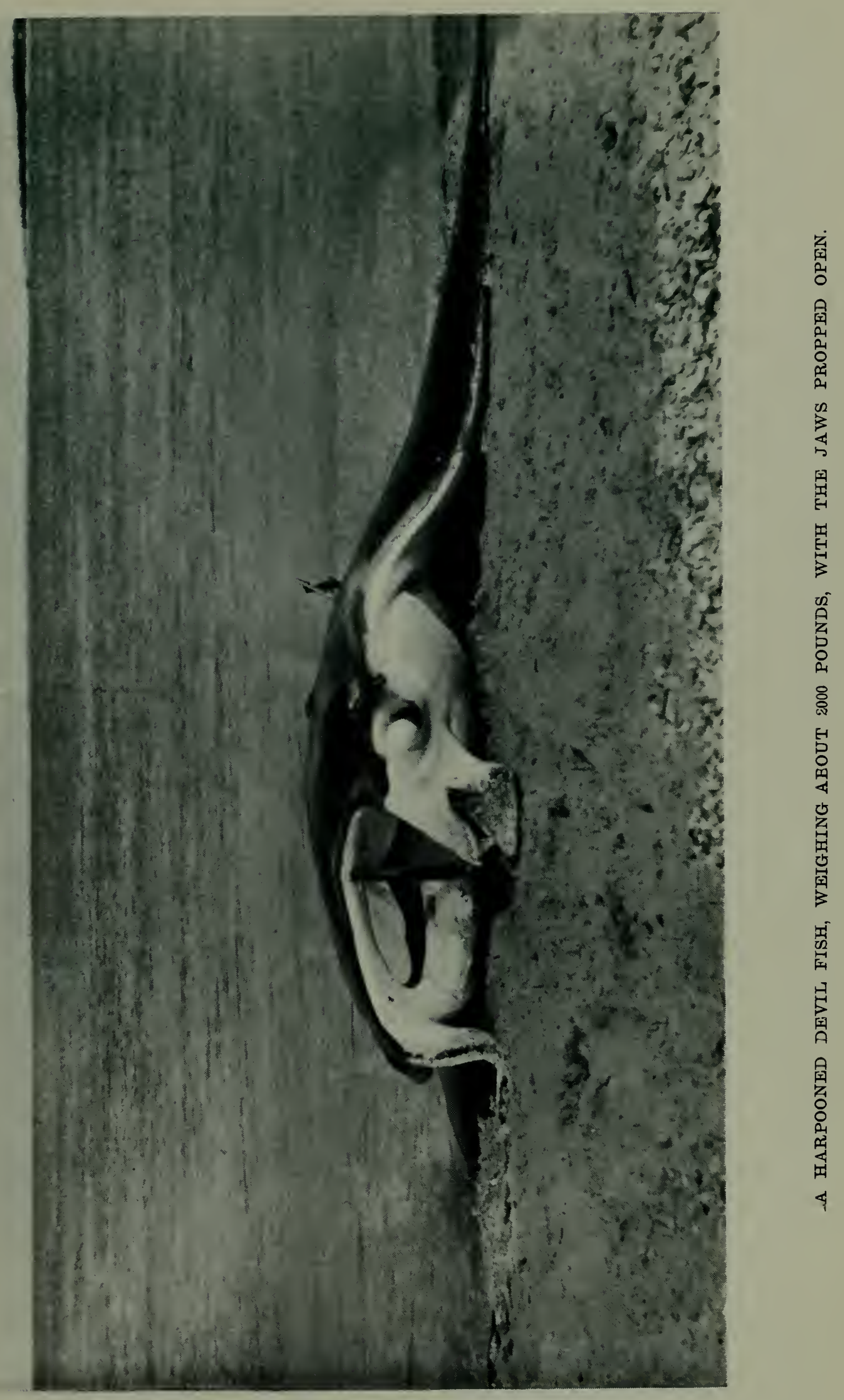





\section{Giant Fish of Florida}

other boats, which had already stopped fishing, to join in the chase, to cut off a corner and hitch on to the circling harpoon boat. A seventh boat from the fishing grounds has failed to make connection, and, before the day is over, others will wish they had done likewise.

On, and ever on, speeds this extraordinary procession, the like of which was surely never seen under other circumstances, propelled by an unseen power to an unknown destination with a force so great that it makes no account so far of the additional strain on its resources. Some have tried to back water as a check on the runaway, and have for their pains been almost thrown out of the boats and had the oars torn from their hands. Onward they tear, the great fish keeping carefully in the deep channel-way, and avoiding treacherous shallows on its unrestrained course to the open sea. When the ray has thus run for five miles, it quite suddenly doubles on its course, with the surprising and discomforting result that the seven boats are tied in a knot. Quickly they will have to extricate themselves, else, as it is impossible to go full speed ahead in that formation, over they must go.

The pace gradually slackens during the next three miles, and at last all oars are shipped and the guides back water. This is not without its effect on the "devil," who promptly heads again for the open sea, and moves on until the shore is but a streak on the horizon. Anxious eyes are now 


\section{Giant Fish of Florida}

seeking for the smoke of the steamer that they hope will have been sent to their assistance. It is two hours or more since the giant was first harpooned, and it is tiring sufficiently to allow of its being brought now and again to the surface to receive a Winchester bullet or two in its spine. Its mighty wings still flap, however, and it is like some great unwieldy water bird for ever struggling onwards. And now the welcome smoke can just be seen in the distance, though it will take the steamer a good hour to reach the ground, and goodness knows how many hours to tow such a flotilla home.

Only two hours of daylight remain, and one of these is well nigh gone ere the steamer comes along, and promptly crashes into the somewhat erratic harpoon boat, striking her fair amidships, almost the worst disaster of the day. Fortunately she was a nice limp boat with scarce a sound rib in her, and she gave so freely to the sudden blow that little fresh damage was done and she leaked but slightly more than usual. The rest of the day's sport, the slaying and towing ashore of the giant ray, was a matter of time only, yet, curiously enough, when that man went harpooning devil-fish again he went alone. The rest of the company had somehow lost all taste for such weird recreation. 
CHAPTER VIII

\section{The Loggerhead Turtle}





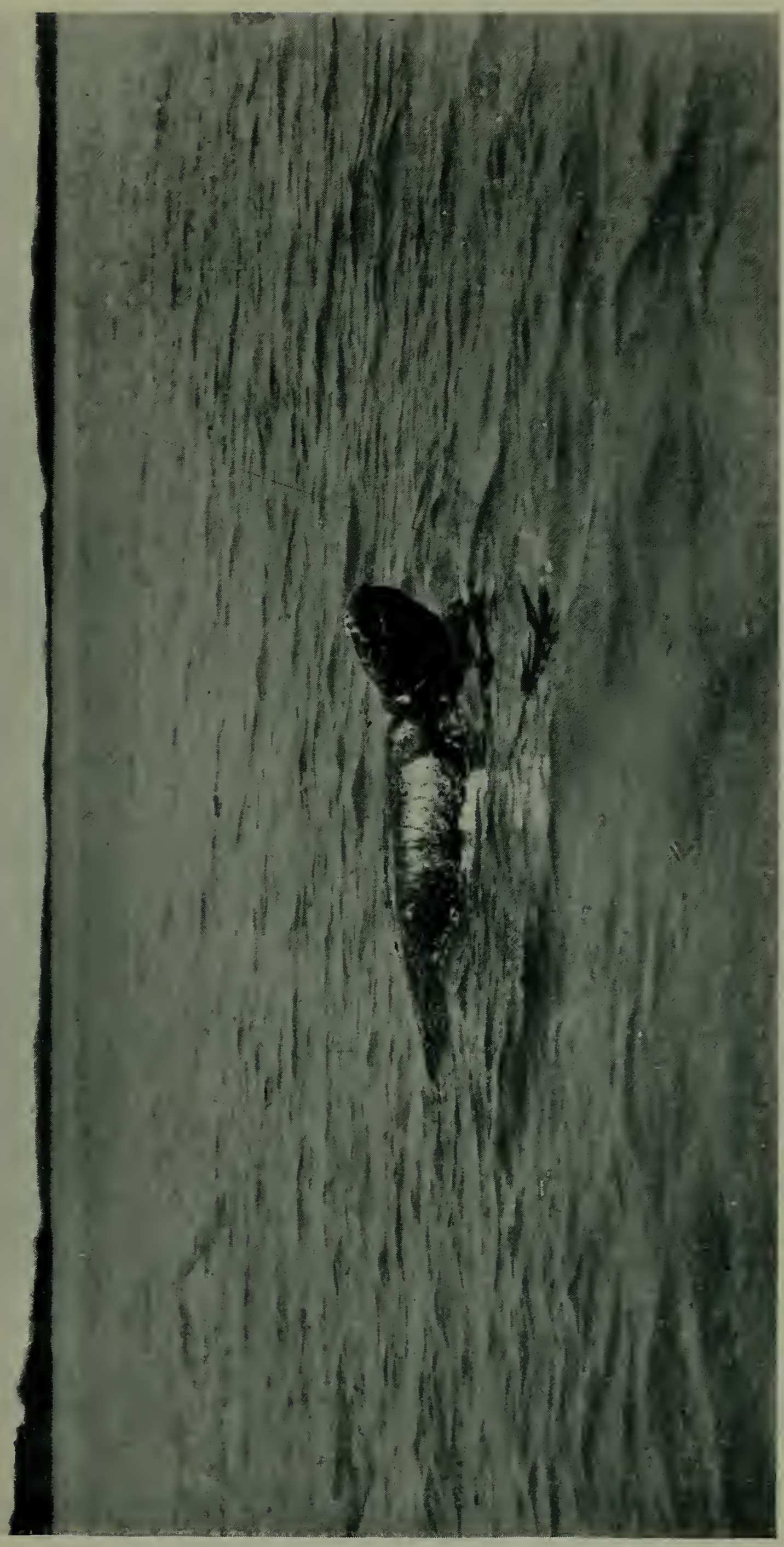

葛 



\section{CHAPTER VIII}

\section{THE LOGGERHEAD TURTLE}

ONE of the favourite objects of the harpoon in those waters is the loggerhead turtle, and as the procedure differs in some respects from that followed in the pursuit of the unprofitable ray, I will attempt to give some account of the way in which amateurs spear their turtle. If you must catch your turtle before you cook him, you must as surely find one before you can spear him. Turtles are in the habit of coming up for a breather somewhere about slack water, and at such times they may be seen basking lazily at the surface.

A small and sharp harpoon is necessary to penetrate the turtle's shell, and it is important to make this change in your equipment if you go from rays to turtles. All being ready, your guide paddles you as quietly as possible into the pass, and you must get in the way of standing motionless in the bow in 


\section{Giant Fish of Florida}

a slight lop, for roughish weather is undoubtedly the best for turtle-spearing.

At length you see a great loggerhead some three hundred yards ahead on the port bow. The loggerhead turtle is the most common on this coast ; the more delicate green turtle is the rarest; and between them in point of numbers comes the leathery species. It is most important, when you have sighted a turtle, to creep up as close and as quickly as possible, without making the slightest noise. You must even stand quite steady and crouch without kicking the boat, as the least disturbance may send the turtle to the bottom. The great thing is to restrain yourself from letting drive with the harpoon until the most favourable moment, and the most favourable moment is that at which you are closest to your quarry, so that it may feel the full force of the harpoon.

If, when you are within reach, the turtle shows signs of diving, in with the harpoon; otherwise, get a little nearer. Now put all your back into the 'cast, and the barbed point goes clipping through the shell. You think that it did not penetrate very far? Well, your instinct is probably correct, so it will be as well to fix another dart ready and, playing him gently the while, strike again the moment he comes up to breathe. He may remain beneath the surface fully twenty minutes, on the move the whole while, but he will soon want air after that time has elapsed. If you were sure of having struck the barb well home, the more usual course 



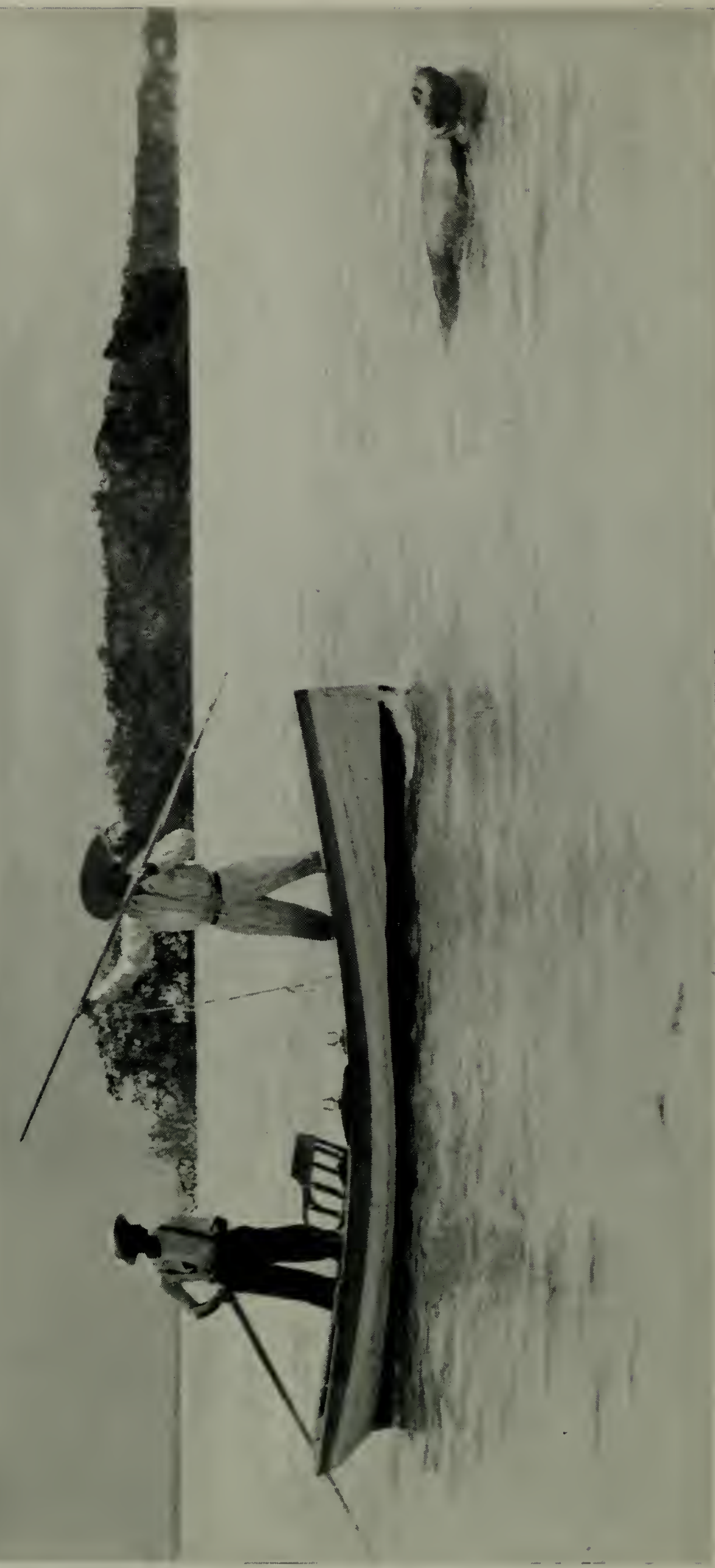

团 


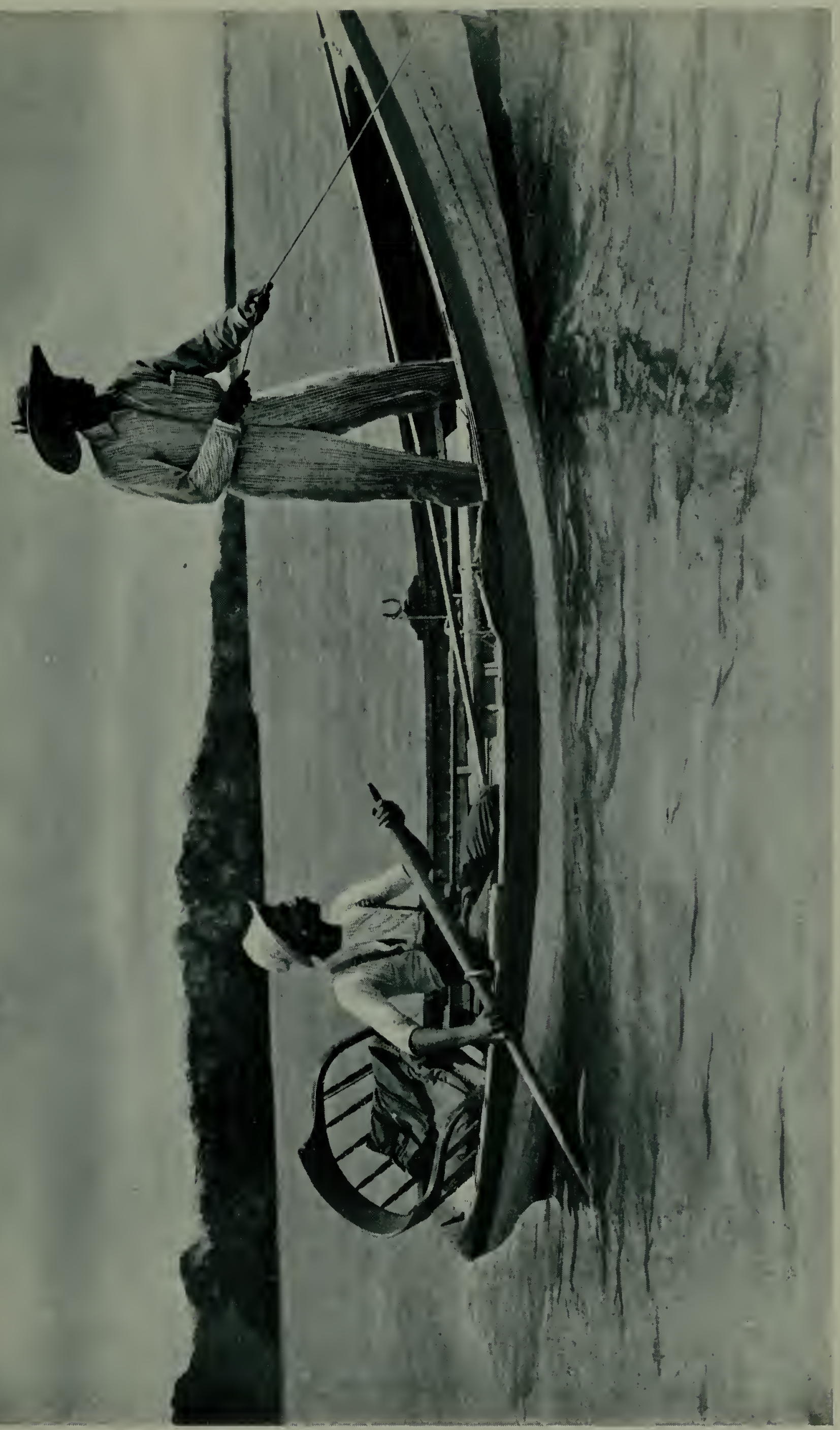

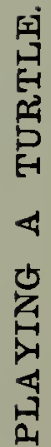





\section{Giant Fish of Florida}

would be to haul in at once; but it is sometimes safe to give the case the benefit of the doubt, and to handle the captive gingerly at first, until a second blow has made things doubly sure.

Up he comes at last; a second barb is driven into shell and flesh; and now, being quite sure that there is a firm hold, you alter your tactics and haul boldly. As he comes floundering to the surface you seize one flipper (careful! that beak, which is fashioned to crush the strongest shells, could easily nip your hand off at the wrist!) while the guide lays hold of the other. You both keep well on the opposite side of the boat to prevent her collapsing, and the turtle, weighing $200 \mathrm{lb}$., is finally lifted in tail first and laid on his back. You are very careful to keep your legs out of his way, for the flippers hit hard and the male's nails tear deep. Blindly in his impotent wrath he flounders, striking out in all directions and chipping away planks like matchwood if he gets the chance.

Before hoisting in a turtle, see that your oars are properly stowed away. We once landed a heavy loggerhead upon an oar half drawn into the boat, with the result that it was driven through the bottom, and the accident discovered only when the boat was a third full of water. In spite of hard bailing, by the time the turtle had been shifted, and the guide had whipped off his shirt and stuffed it into the hole, the boat was in a sinking condition, and the turtle had most of the fun to itself. 


\section{Giant Fish of Florida}

Though its reputation is deservedly less than that of its green relative, the loggerhead nevertheless makes excellent soup, but you have to dress your own turtle if you want to utilise it in this way. The first thing is to kill it, and killing a turtle is easier to write than to do. Its head must be cut off at any cost, and the particular cost to avoid is having your fingers nipped off. Always bear in mind that the shell is a very important part of the skeleton; the ribs and neck are firmly joined to it. The big bones fore and aft, as well as the shoulder blades and pelvis, are separate; otherwise all the solid parts and the shell are one. I am not desiring to discourse on the anatomy of the turtle, but this unity with the shell is worth remembering by any one attempting to remove the head.

To get at the turtle's best meat you have to cut round the margin of the under plates and lift up the lid. Even then, unless you have some experience of the composition of the animal, it is by no means easy to be sure that you have struck the liver, and not some other part that you do not want. A turtle is one of those creatures that do not seem nearly dead when you have killed them. When the turtles are pairing, by the way, nothing will drive them from each other's company, and there can under the circumstances be no possible sport or advantage in killing them, particularly as the male is then unfit for food.

Such are some of the fruits of harpooning. It will be found a pleasant change, exercising a new combination of the senses 


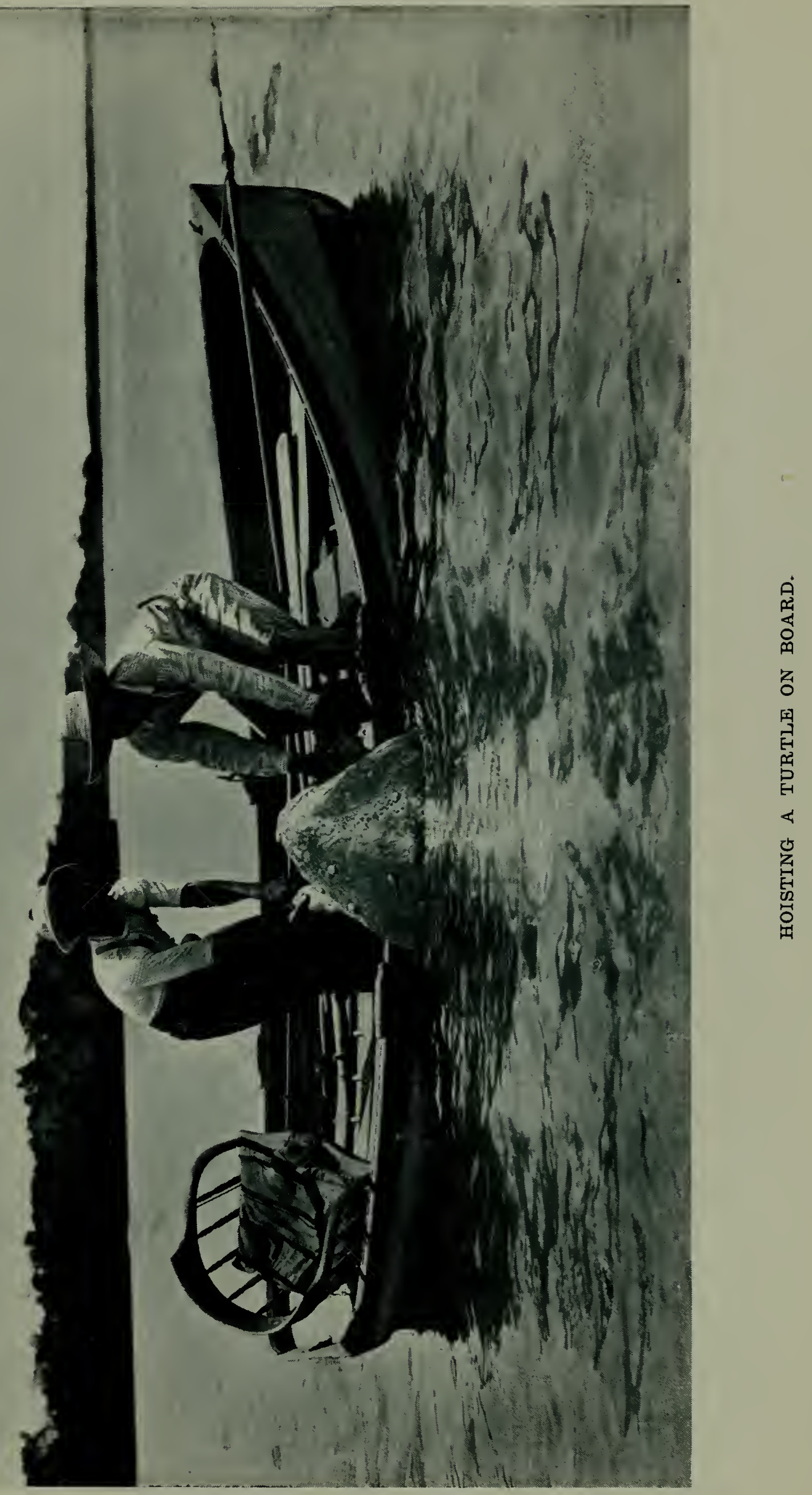





\section{Giant Fish of Florida}

and muscles, and requiring some skill; but it is, of course, only a bastard form of sport, and is usually resorted to on days when the tarpon will not feed, or the tide is too strong for fishing. The turtle is the only useful animal taken on that coast by such means, and there is this excuse for harpooning your turtle that you cannot get them in any other way. The turtle's cousin on land, the gophir tortoise, which is common enough in those parts, is said to be taken in a very curious way, though, as the animal is useless, few put it to the test. This tortoise lives in underground burrows, not unlike rabbit earths, and its abundance may be judged by the number of such burrows. Into these the natives say they drop a ball attached to a string, a sudden intrusion that infuriates the occupant of the burrow, who, in his slow and sure fashion, pursues it into daylight, and is then easily secured. I hand on the story for what the cautious reader may think it worth. Personally, I am not much inclined, from my limited knowledge of reptile habits, to credit it.

The turtles come ashore in the warm May nights to lay their eggs, and the female, as soon as she touches land, raises her head and peers cautiously around to see that the coast is clear. Satisfied on this point, she scrambles on to the dry sand and above high-water mark, scrapes a hole and therein deposits her eggs, covers them up, and returns to the sea. Three sittings she will lay each season, and many a banquet is thus provided for racoons. It is at this laying 


\section{Giant Fish of Florida}

season that so many turtles are procured for the market, and many a loggerhead finds its way into the real green turtle soup.

In their wanderings below the surface they not infrequently get foul of a line, but, so hard is their skin, that the hook seldom penetrates. Some idea of the toughness of the skin may be formed when it is mentioned that even the strongest men can with difficulty pierce it with a gaff. When they chance to foul a line they are generally played for about half an hour, after which they show once and then go free. On one occasion the harpooner of the party slowly and cautiously approached a basking loggerhead, his right arm poised, his weapon ready to strike. Then, slowly, it was lowered; the turtle must have been dead at least a week. Yells of laughter greeted his discovery, for the decaying reptile had drifted down the whole line of boats, reaching him the last, and had even deceived one or two of their inmates into fetching out their gaffs. 


\section{CHAPTER IX}

\section{Catfish as Scavengers}





\section{CHAPTER IX}

\section{CATFISH AS SCAVENGERS}

WITH the exception of the sharks, which, vermin as they are, give a measure of sport under favourable conditions, I have now disposed of most of the really big game of the Florida coast waters, and it remains to draw the reader's and intending visitor's attention to the number of other sea-fish that on occasion give excellent sport in those latitudes. I have often thought that in the all-absorbing ambition for the record tarpon some of these humbler fish, which would themselves create a sensation in English waters, are too consistently neglected. The sharks shall receive notice where their low standing as vermin relegates them, at the end of the book.

It may be complained, particularly by those who have never been on the spot, that I have passed too lightly 


\section{Giant Fish of Florida}

over the real art of tarpon fishing, made too little of its difficulties, laid too much stress on the simplicity of success. Well, these are matters of opinion. I never, in my own tarpon experiences, found a single instance where real skill and expert knowledge were nearly so important as brute strength and endurance, and I write only of what I know. Those who like detailed instructions in the art of tarpon fishing should consult the back files of Forest and Stream, the great American fishing paper, and in these they will find innumerable excellent articles and letters on the subject. In a quite recent volume, for instance, I find an admirable series of tarpon papers from the pen of Mr. J. A. L. Waddell, and I append, as a specimen of the detail with which some of these writers lovingly handle their subject, Mr. Waddell's twelve ways in which a tarpon may be lost by the careless or ill-starred.

I. By failure of the hook to penetrate a soft place.

2. By the cutting of a hole in the mouth, from which the hook drops when the line is slackened.

3. By breaking or corkscrewing the hook.

4. By breaking the line, owing to :-

(a) its deterioration.

(b) fouling of line by overrunning of the reel.

(c) tangling of something by the reel handle.

(d) too severe application of the brake or reel handle in order to stop the fish. 


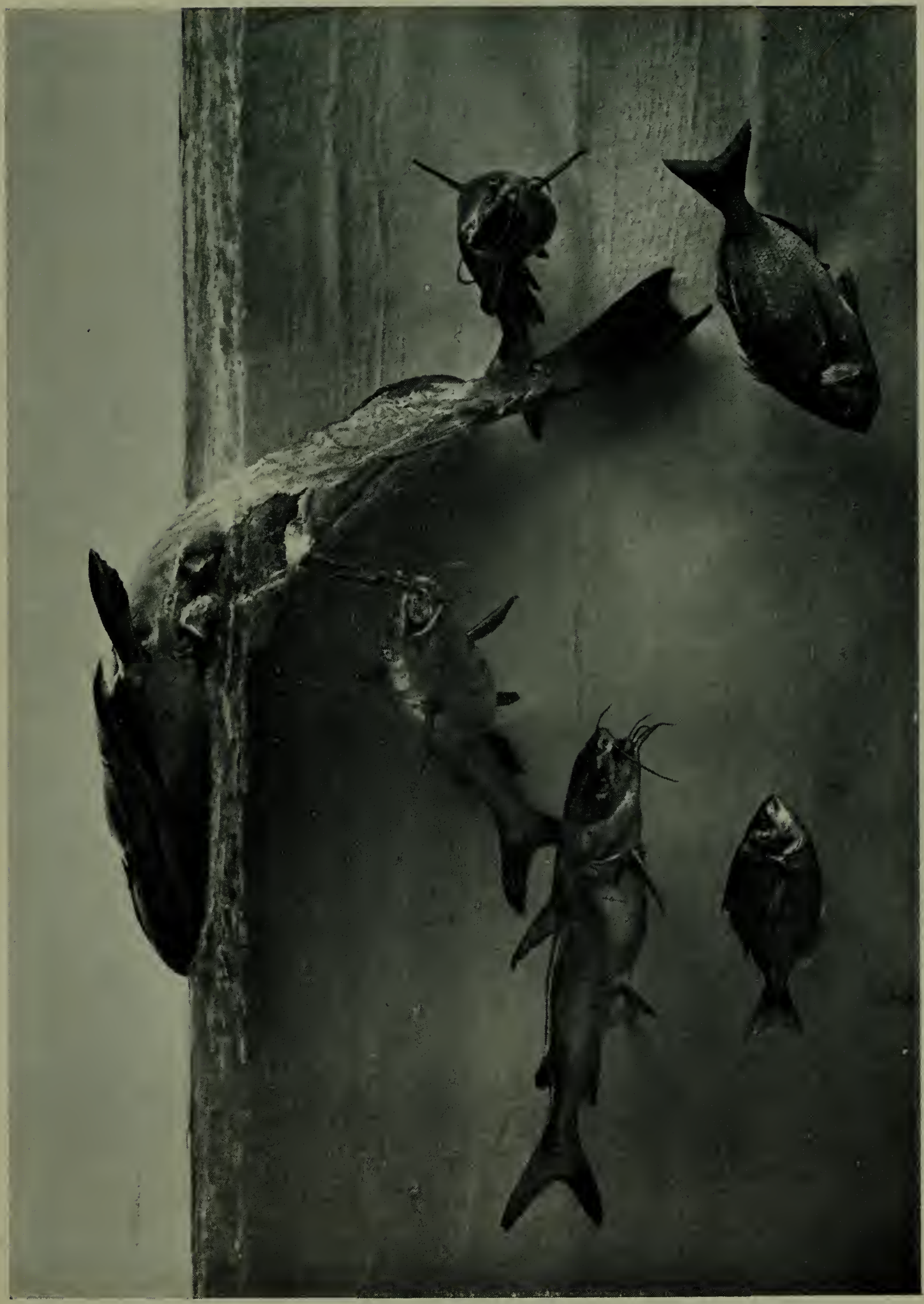

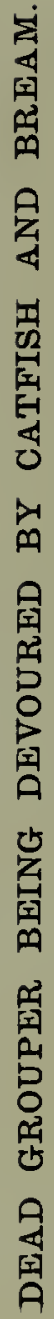





\section{Giant Fish of Florida}

5. By breaking of the snell.

6. By breaking of the rod, generally in the tip, but sometimes in the butt.

7. By carelessness of boatman in gaffing.

8. By attack of a shark.

It remains to put before the intending visitor to Florida some of the commoner but yet interesting sea-fish, less game than the tarpon, less immense than the jewfish, that will under a variety of conditions, and on days when the tarpon itself is out of reach, afford excellent sport. These notes are not, of course, addressed to the expert naturalist ; indeed, they are for the most part very brief, and serve chiefly to introduce my photographs, which may, perhaps, claim to be the most characteristic series of the kind yet published.

\section{The Common Catfish (Galeichthys felis)}

As the turkey buzzards on land, so the catfish in the sea act as scavengers that we could ill dispense with. The sharks, on the other hand, with their fiercer and more predatory instincts, may rather be compared with the eagles among birds. These catfish are, as may be seen from the photograph, not beautiful to the eye. Neither, for the matter of that, is the condor, yet it is, perhaps, of more use to South America than the humming bird.

We here see a trio of catfish busy on the carcase of a monster grouper that floats dead on the surface; and what 


\section{Giant Fish of Florida}

would become of such polluting offal but for services such as are rendered by these useful scavengers, one shudders to think. These catfish have no scales, their bodies being shiny, and sleek to the touch, but the fisherman must beware of insidious spikes hidden behind the fins. Any one familiar with the salmon will not fail to notice a similar adipose fin on the back of the catfish, in front of the tail, and the other distinctive feature is the growth of whiskers, in reality sensitive feelers, on the head. Many catfish are found only in the rivers of the warmer regions of the globe, and German and Austrian anglers have their own siluroid in the giant wels of so many continental rivers and lakes.

In the picture will be seen a couple of sea-bream, apparently hovering around to pick up the leavings of the larger fish, and, for this or some other reason, sea-bream are very often caught in company with catfish.

Catfish and buzzards are not the only scavengers of that coast. No tarpon that is wanted again should be left on the shore, for no sooner are you out of sight than every hole and cranny in the sand above high-water mark gives up its ghostly crabs, elfish little body-snatchers that creep stealthily, and quickly eat their way into the soft parts of the fish. Ghostcrabs they call them thereabouts, and phantom-like they look when disturbed and tearing seawards with their attenuated white legs held on high. 


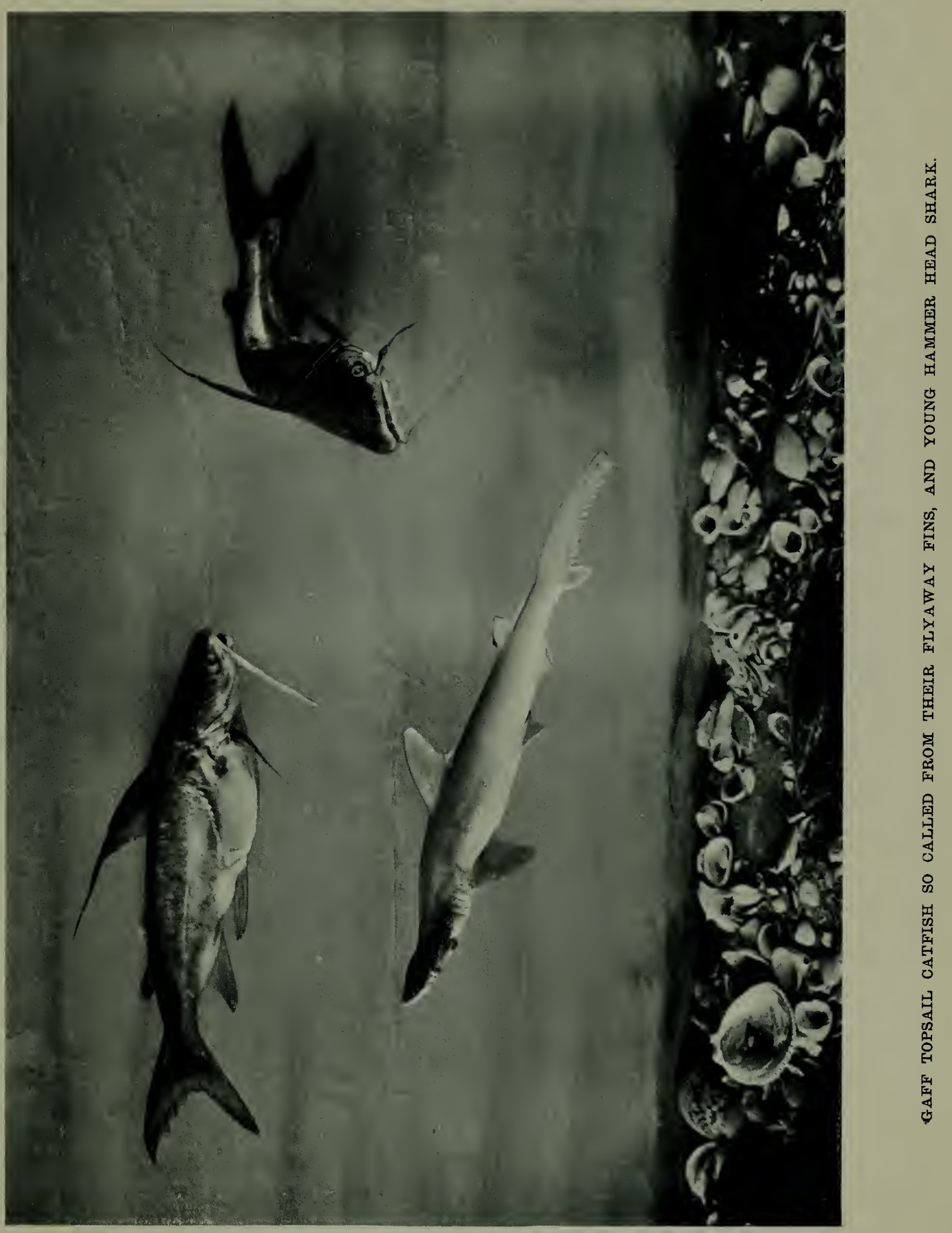





\section{Giant Fish of Florida}

\section{The Gaff Topsall Catfish (Elurichthys marimus)}

In the gaff topsail catfish there is not merely an extraordinary development in the "whiskers," but the back fin also carries a long threadlike growth not unlike that in the tarpon. All these catfish frequent sandy grounds, and are rarely found in the clearer coral waters. The present species runs to greater weights than the last, and it is as a rule found both farther from land, and in deeper levels. As they are all inoffensive scavengers, and by no means the fierce creatures they look, it is difficult to account for their being so often hooked by tarpon fishers, except by the probability of their endeavouring to suck the baits off, and getting foul hooked.

All catfish are active at night, which might be thought to account for their popular name, only that they are on the feed all day as well. It is nevertheless a pretty sight on hot nights when the sea is highly phosphorescent to throw morsels of fish or meat into the water, and watch the balls of fire darting in all directions as the catfish and others dash to their repast.

In the picture will be seen a baby hammerhead shark (Sphyrna zygcena), a rather interesting personality, for it had not long been born when photographed, and had not in fact developed the singular "hammer" of a later stage, its eyes being still flush with the sides of the head, and its only distinction from the more typical sharks lying in the extraordinarily prolonged snout. I give a photograph of an adult hammerhead later on. 


\section{Giant Fish of Florida}

\section{The SheePshead (Archosargus probatocephalus)}

I mentioned the sea-bream in writing of catfish, and one of the commonest of the group on that coast is the sheepshead, so-called, I imagine, from the solid, sheeplike teeth that can even crunch the mangrove oysters, in the neighbourhood of which these fish are so fond of foregathering. These growths of oysters on the red mangrove always attract the notice of visitors unused to the spectacle. The best bait for these bream is a fiddler crab, a crustacean found in every lagoon thereabouts, and owing its name to a singular habit of waving its large claw (only the male has this disproportionate limb) exactly as if it were drawing a bow across a fiddle. As the seabream are fond of company, playing one is generally the prelude to a good bag of them. They bear little resemblance to their namesakes of rivers and ponds, for they are not so slimy or sluggish, but on the contrary more spiny, and have the dark band markings and game fighting manner of perch. They feed not far from the bottom, and must be struck sharply the moment they bite, and for their size they play very well. They can be taken in immense quantities. 



\section{CHAPTER X}

\section{Bony Fish, Jack Fish, Jewfish, Squeateague and Bass}





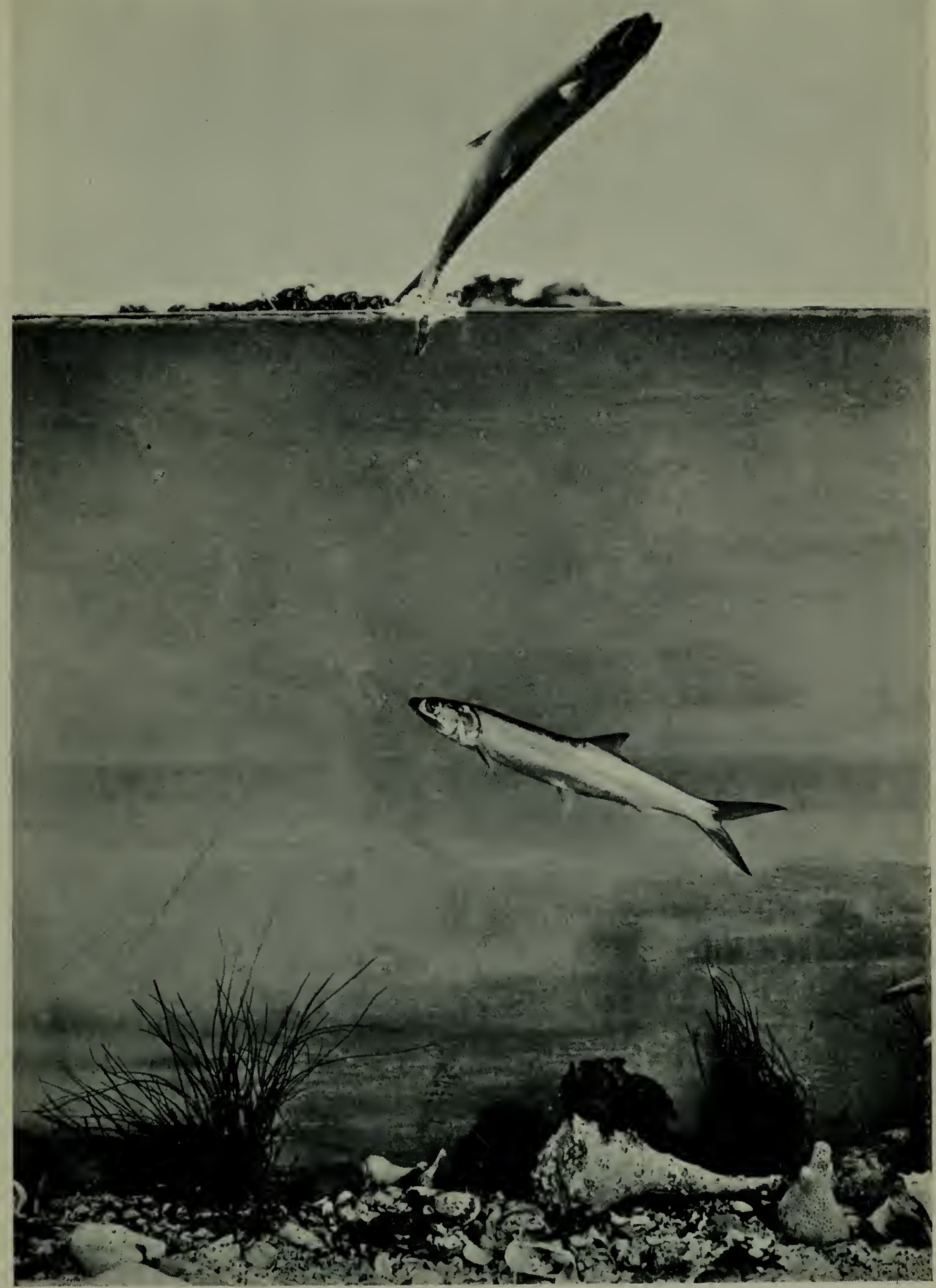

A FAT TOAD FISH SQUATTED AT THE BOTTOM WATCHING THE SLIM BONY FISH AS THEY LEAP. 



\section{CHAPTER X}

BONY FISH, JACK GARFISH, JEWFISH, SQUEATEAGUE

AND BASS

BONy Fish (Elops saurus) AND TOAD FISH (Antennarius marmoratus)

THIs active and graceful fish, a near relative of the tarpon, which perhaps derives its name from its leanness, rises freely to the fly under favourable conditions, and its wild jumps make lively sport. Its several popular names are puzzling-there is a tendency on the other side to eccentric naming of fish-and no fish is considered genteel without at least three or four to choose from. 
Under the two bony fish in the photograph will be seen, on a shell, one of the remarkable toad fish clinging to its support and lying in ambush for unwary small fry. This particular specimen, of which I give an enlarged presentment, seems a very primitive creature, with its handlike fins and tiny eyes and general absence of vitality, yet it is admirably equipped for satisfying its own greed and escaping that of its enemies. It is all but invisible clinging to the shell against a deceptive background of weeds, and its gaping mouth is striped black and white inside in an attractive manner that proves the doom of many fish endowed with a fatal curiosity. This particular individual, indeed, had actually swallowed a young snapper of exactly its own weight and half an inch longer than itself! I relate this merely as it came under my own notice, for I took the one from the other, but I hardly expect to be believed. 


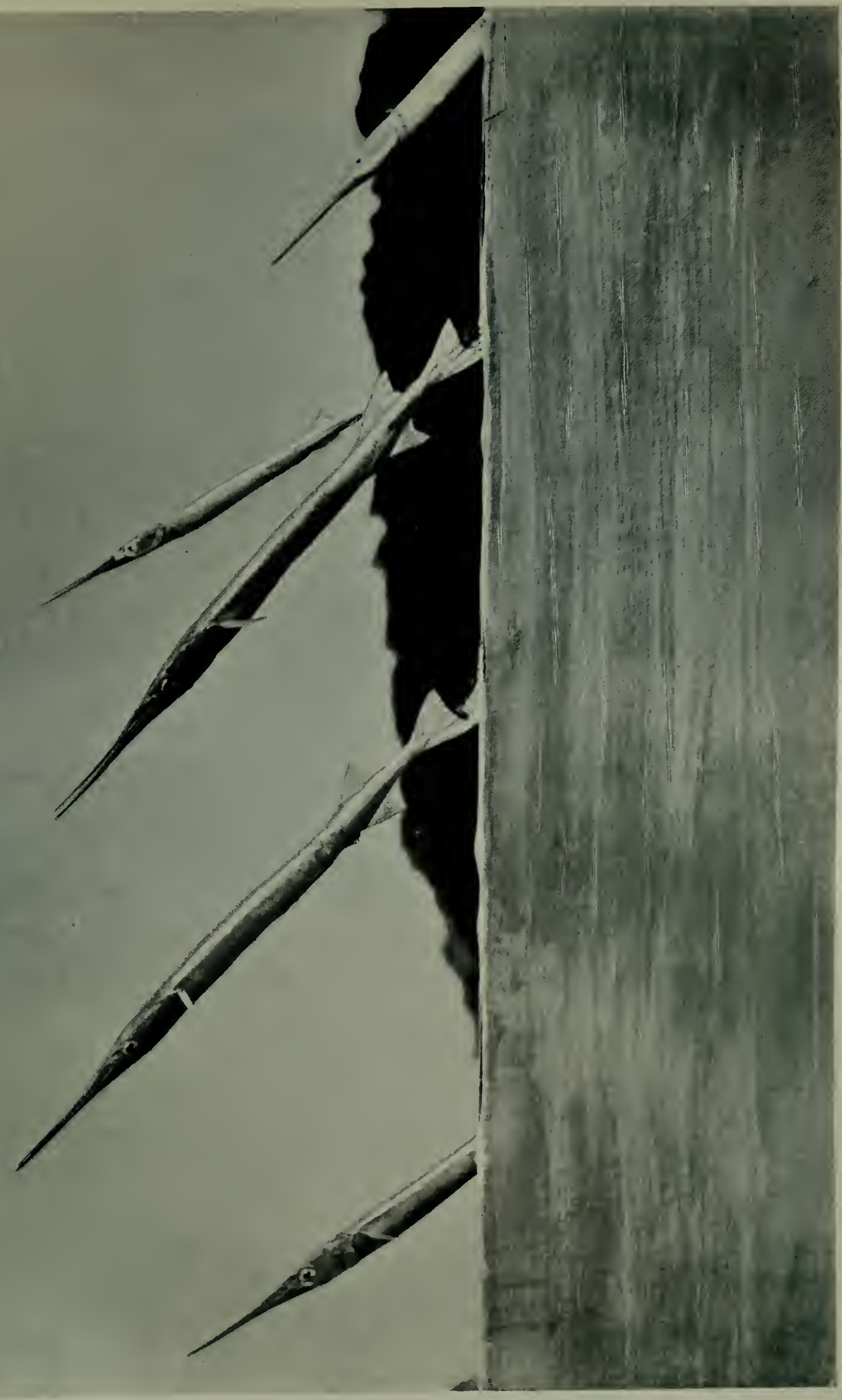

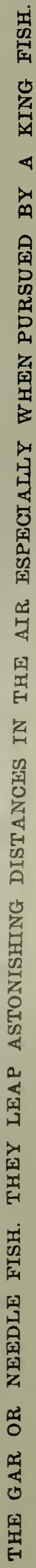






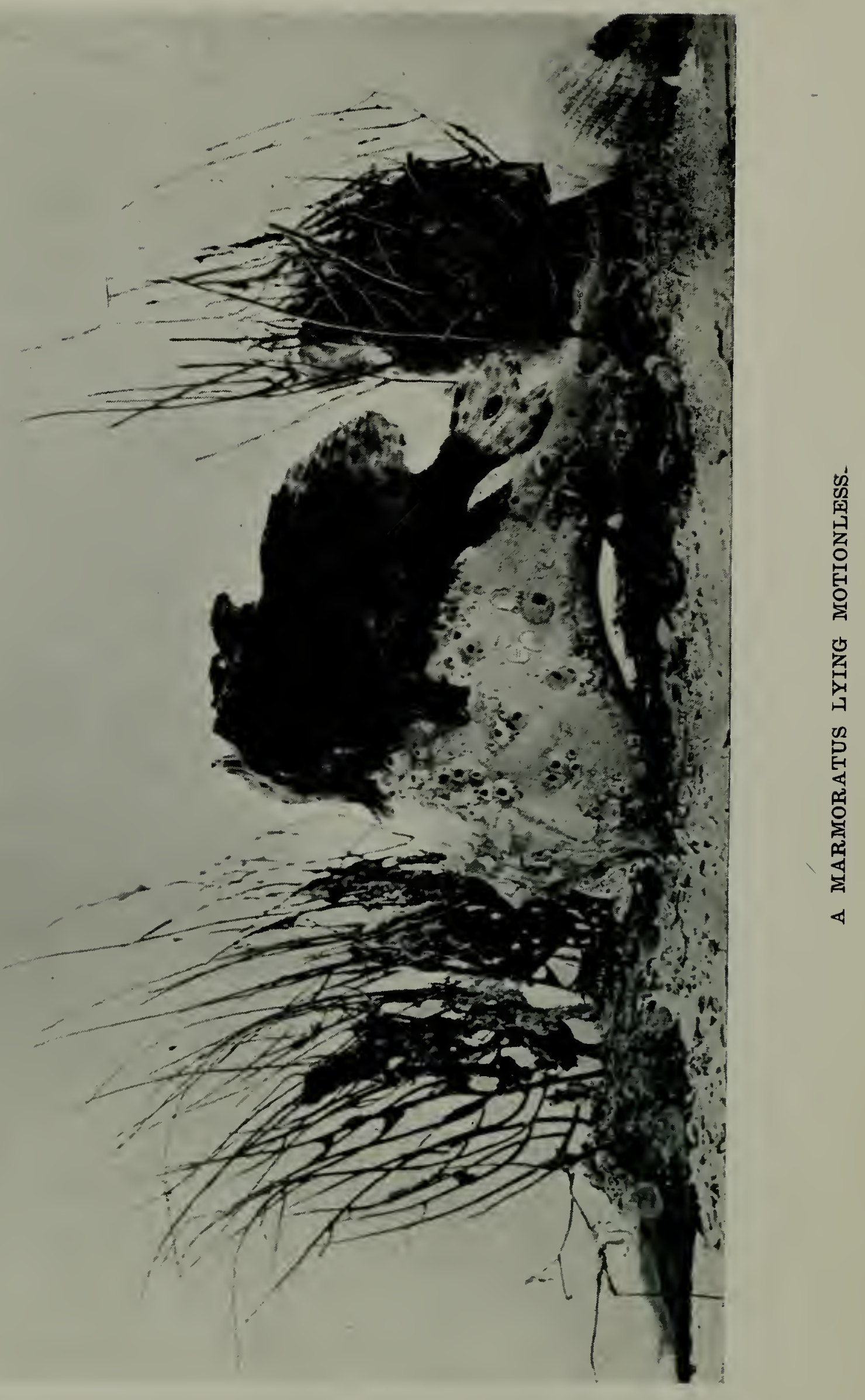




\section{4}
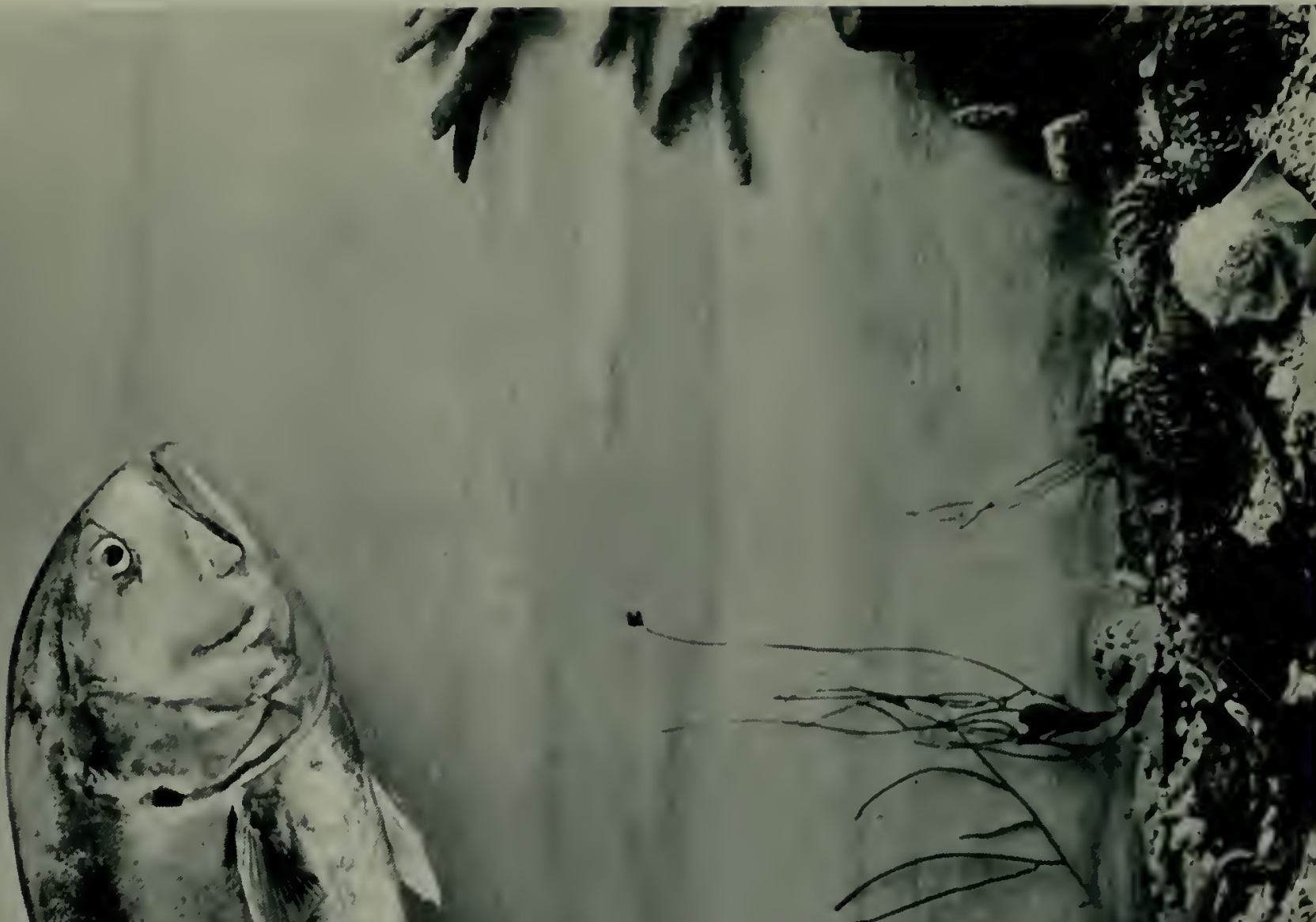

,
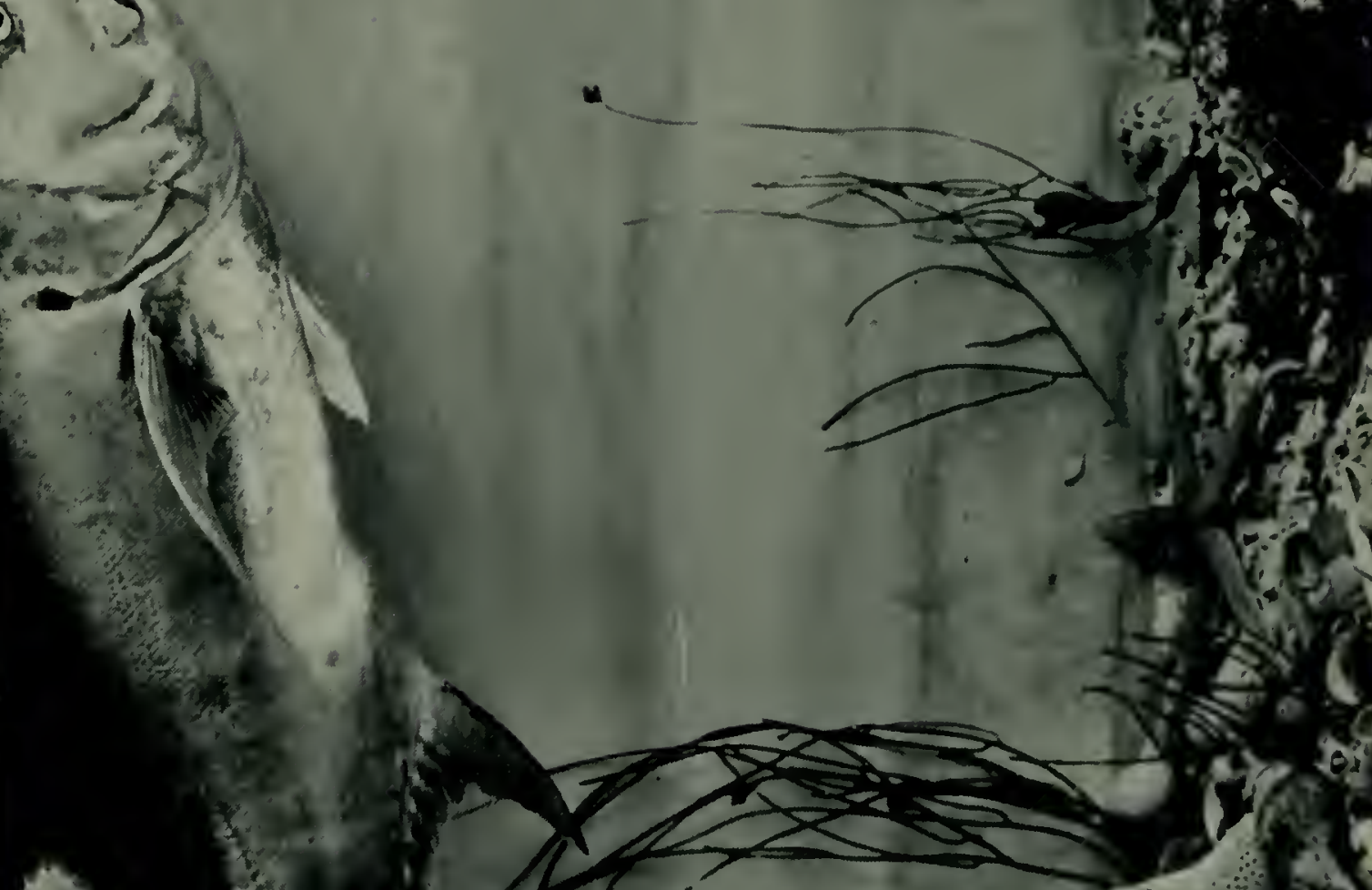

$\tan F \cdot \sqrt{2}$<smiles>[CH]1[CH]C1</smiles>

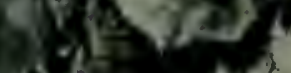

1)

is 



\section{Giant Fish of Florida}

The Cavally or "Jack" (Caranx hippos)

The scad, or horse-mackerel, are familiar in most seas; even on the British coasts we have them. In warm latitudes, however, they are beautiful as well as bold, and the combination of burnished silver and metallic blues and yellows on the favourite "jack" of Florida waters make him a very handsome fish. Like all the horse-mackerel, he is capable of wonderful bursts of speed, and takes all manner of baits, particularly those not intended for him. He is not much fished for purposely, but may be regarded as one of the miscellany that one time or another come to the basket of the sea-fisherman at Boca Grand. There is no doubt that if fished for with the fly to which he will rise, so strong a fighter would show very fine sport. 


\section{Giant Fish of Florida}

The Garfish (Belone spec.)

The flying fish is by no means common, though probably existent on that coast, but it has a relative in the garfish; and, though this does not commonly do much flying, it can on occasion, as when pursued by a swift and powerful enemy, throw itself clean out of the water with much energy, and can propel itself for thirty yards in the air by occasionally tipping the water with its tail. In this case the garfish are alarmed by a kingfish that is really after a skipjack. A good deal of prejudice exists against this fish at home, on account of its green bones (I take this to be the same species that swims in British waters), but it is first-rate eating. Garfish may be found, as a rule, close in amid the surf, where they hunt for small, thin-shelled sandhoppers, about the size of French beans. One of these on a small hook is, in fact, the best bait if any one wishes to angle specially for garfish, but the long bill and the presence inside it of innumerable needle-like teeth do not make the work of extracting the hook particularly pleasant. 


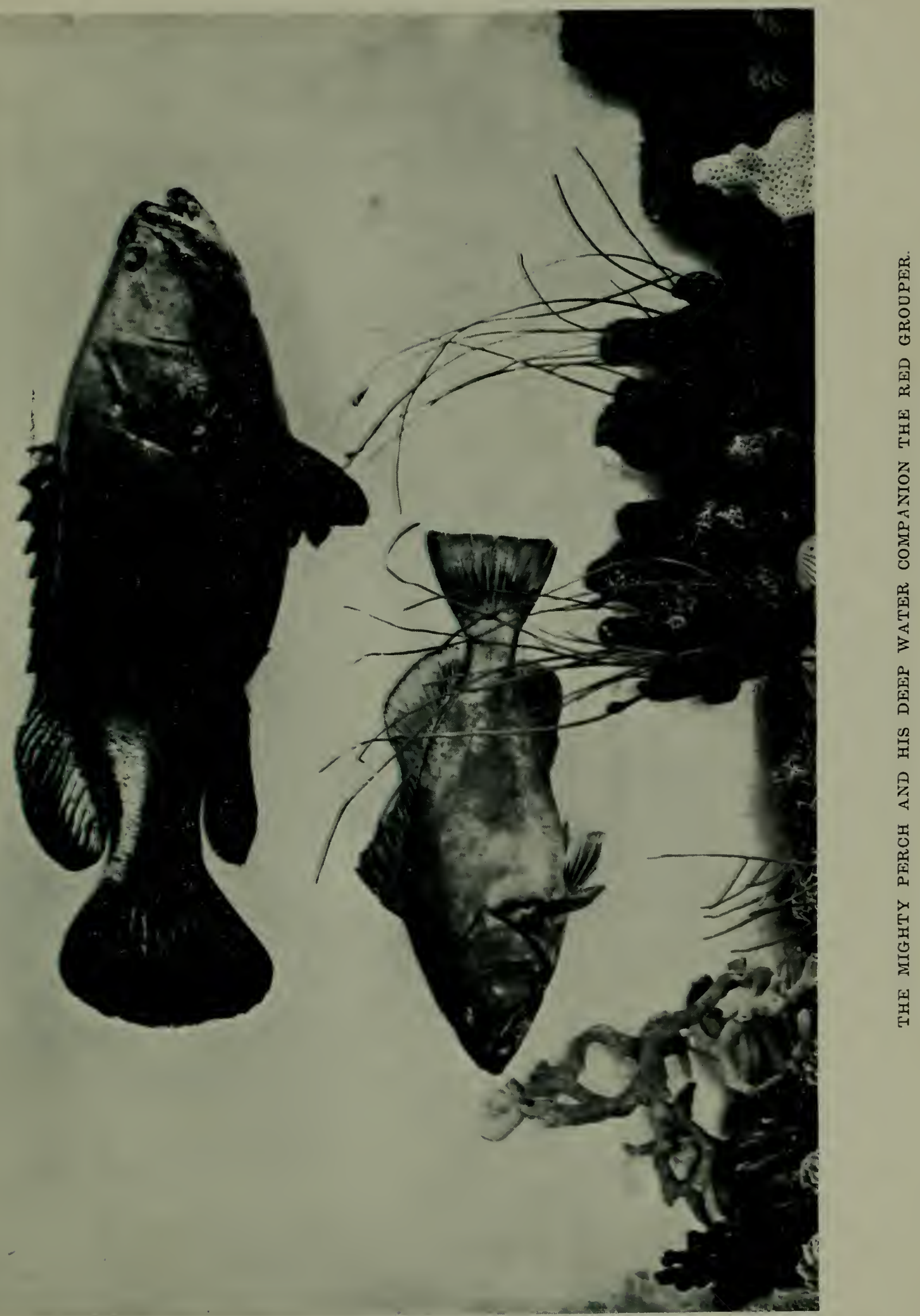




\section{Giant Fish of Florida}

JEWfish (Promicrops guttatus) AND RED GROUPER (Epinephelus morio)

Of the jewfish enough has already been said. The lower figure in the photograph is a red grouper, a large deep-water fish with a good deal of pale red on the head and throat, and a more vivid red inside the mouth. It is a vigorous fighter when hooked on deep rocky ground, and makes an excellent table fish, but it is not so common as the black grouper. 


\section{Giant Fish of Florida}

The Spotted Squeateague or "Sea Trout" (Cynoscion nebulosus) and Ground Spearing (Scirus myops)

The subjects of this photograph are not salmonoid fish out of drawing, as might at first sight appear, but fish, miscalled "trout," of Gulf waters that give fine sport when hooked. As if in vindication of its spots and name, this "trout" will often take a grilse fly when on the feed. It is a strong fighter and jumps continually. It is usually taken spinning with reel or artificial bait. Found on the sandy grounds, it is in some favour as a food fish. Many visitors fail to take with them a light fly rod ; hence these very sporting fish are done to death on a kind of miniature tarpon rod in a hand-over-hand fashion, whereas they would otherwise afford nearly as much sport as a four-pound lake trout. On the sea bed, beneath the squeateagues, will be seen a ground spearing. 



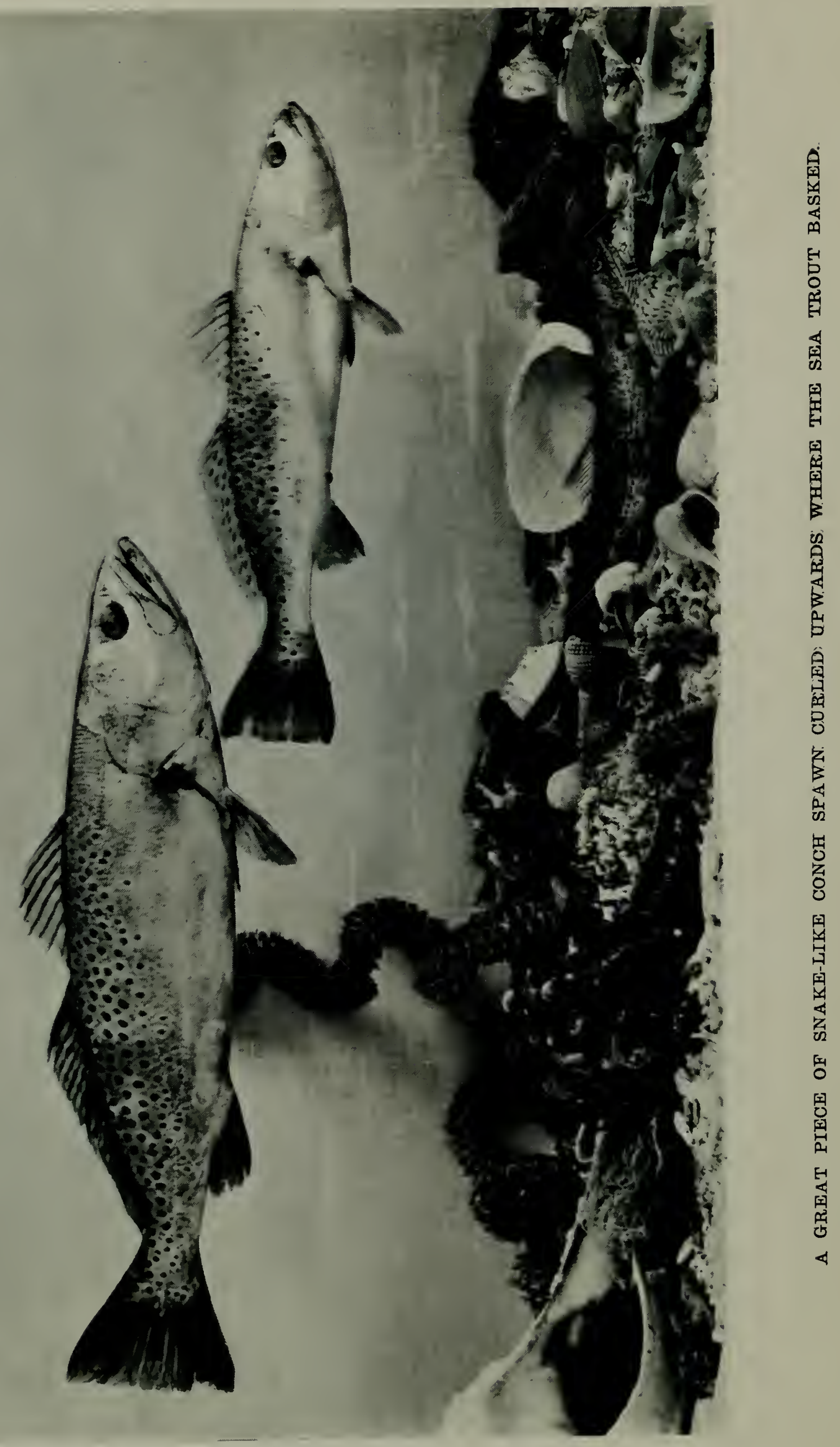




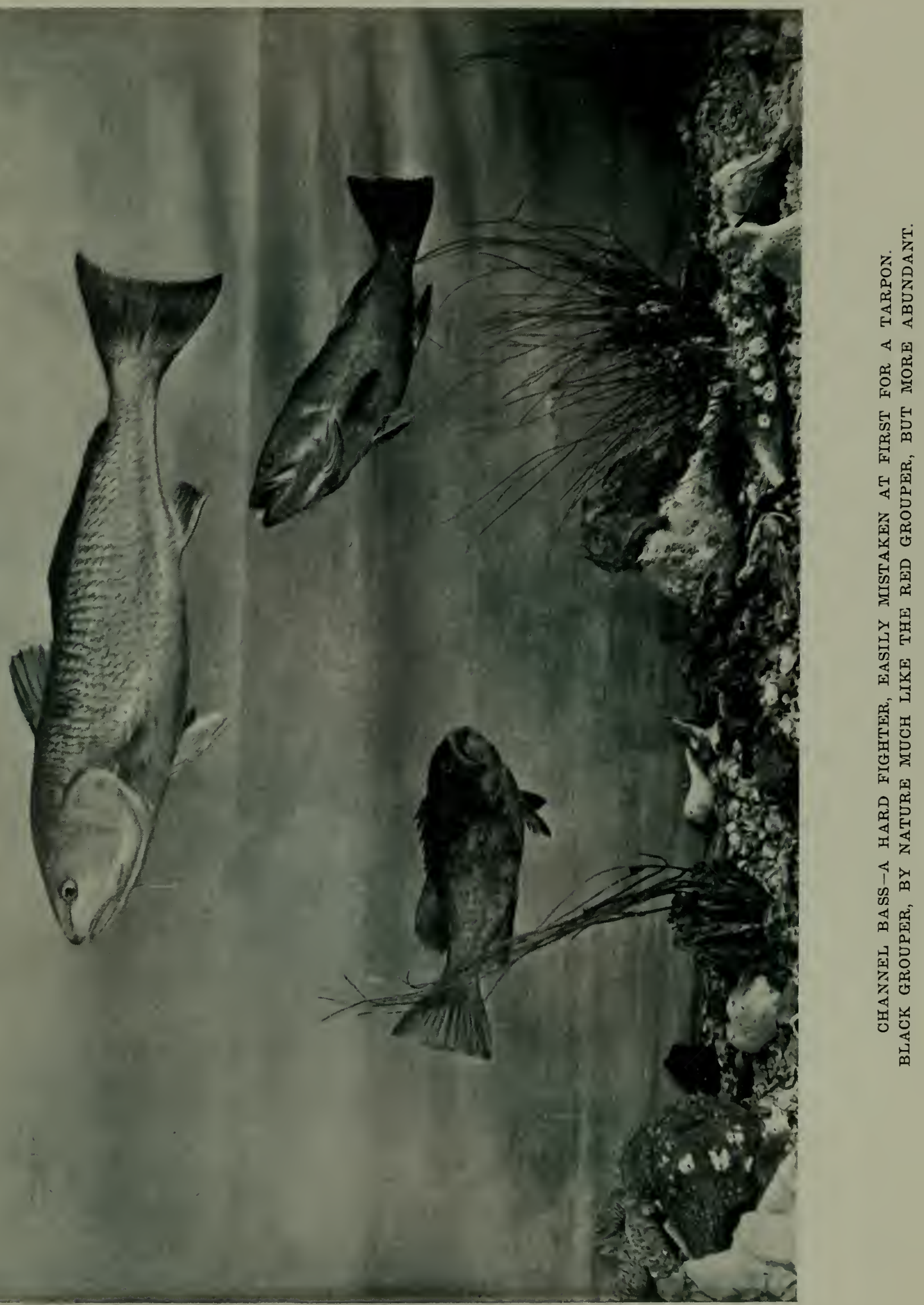





\section{Giant Fish of Florida}

Channel Bass (Scicenops ocellatus) and Black Grouper (Garrupa nigrata)

The channel bass, or red drum, is a bronze fish that runs up to 40 or $50 \mathrm{lb}$. weight, and gives good sport on a rod in the surf. So many of the smaller sporting fish are caught in the surf on the Florida coast, that I have often wondered whether this is a merely local habit, due to their dread of the sharks outside, or whether indeed sea-fishermen at home neglect the more productive surf, in their haste to fish the extreme end of a long pier or the deeper waters attainable in boats.

The black grouper is a great trouble to the tarpon fisher, for on some days it seizes bait after bait, and at once darts into some convenient crevice in the coral. The puzzled angler strikes again and again, and each time finds himself hitched into the rock, which often entails the loss of all his tackle with many feet of line. Only the old hand knows the real source of the trouble and promptly changes his ground, but as those fish are more or less numerous all through the pass, the real secret of avoiding them is to fish a few feet higher. 



\section{CHAPTER XI}

Spotted Eels, Crab Eaters, Surf Whiting, Moon Fish, Leather Jackets, Trigger Fish, and Mullet. 



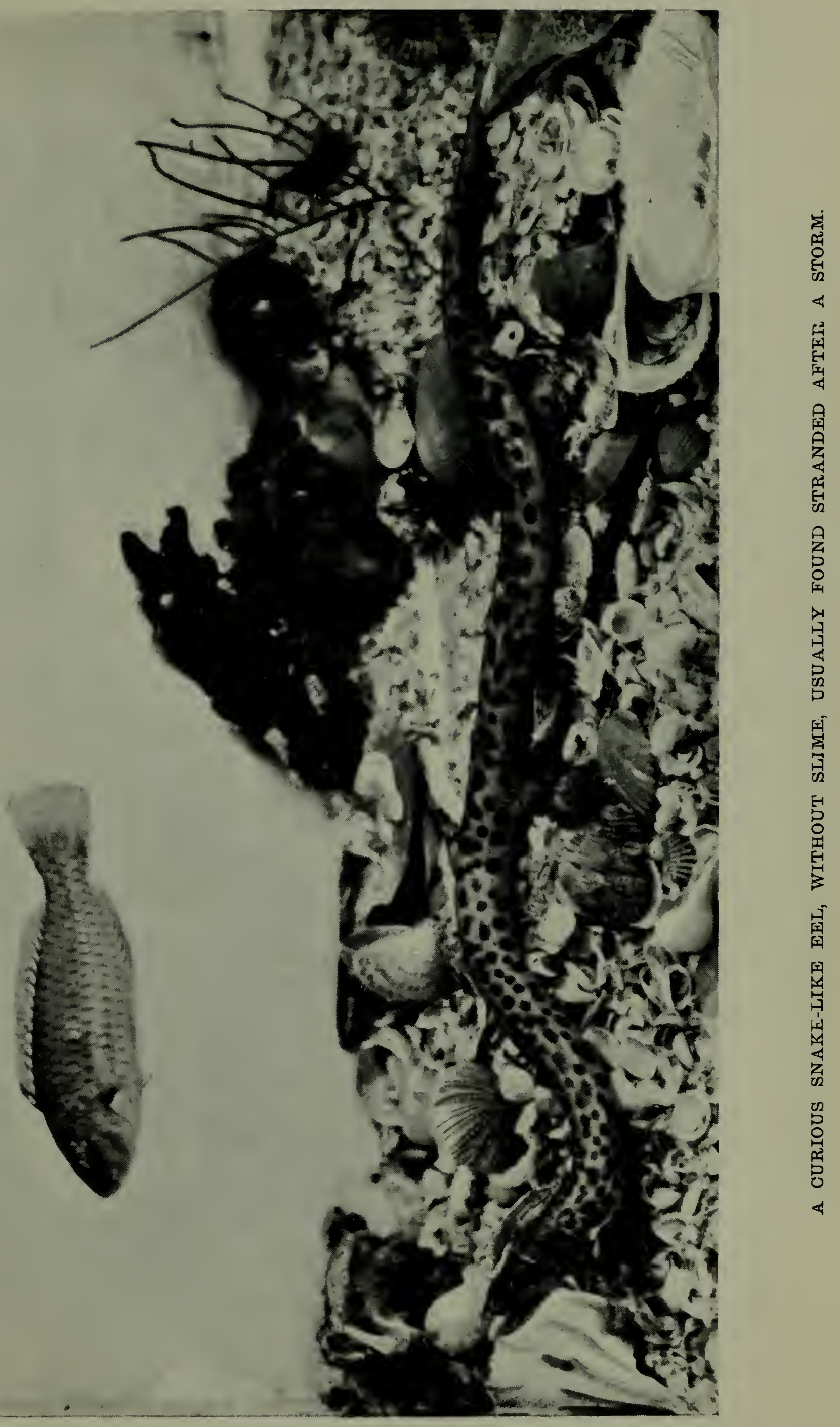





\section{CHAPTER XI}

SPOTTED EELS, CRAB EATERS, SURF WHITING, MOON FISH, LEATHER JACKETS, TRIGGER FISH, AND MULLET

SPOTTEd EeL (Mystriophys intertinctus)

THERE is something peculiarly snakelike about these yellow, black-spotted eels, which are only found washed ashore after storms from a certain quarter, and never, at any rate to my knowledge, take a baited hook. There are many of these spotted eels in the waters round Florida Keys, and one of them is known as the "sea-serpent."

The small upper fish in the photograph is evidently a wrass of some kind, probably a rock-cook (Centrolabrus), but as no one catches the wrass, save by accident, I never studied them. 


\section{Giant Fish of Florida}

COBIA OR CRAB EATER (Rachycentron canadus)

This handsome and sporting fish is allied to the mackerel, and in some parts, indeed, goes by the name of "bonito," though the true bonito is more closely related to the tunny. Its specific name is a good instance of the singular inappropriateness of some such titles, for it does not occur in Canada. The cobia grows to a length of four or five feet, and is a dashing fish when hooked, though it is not very common in the angler's catch. 


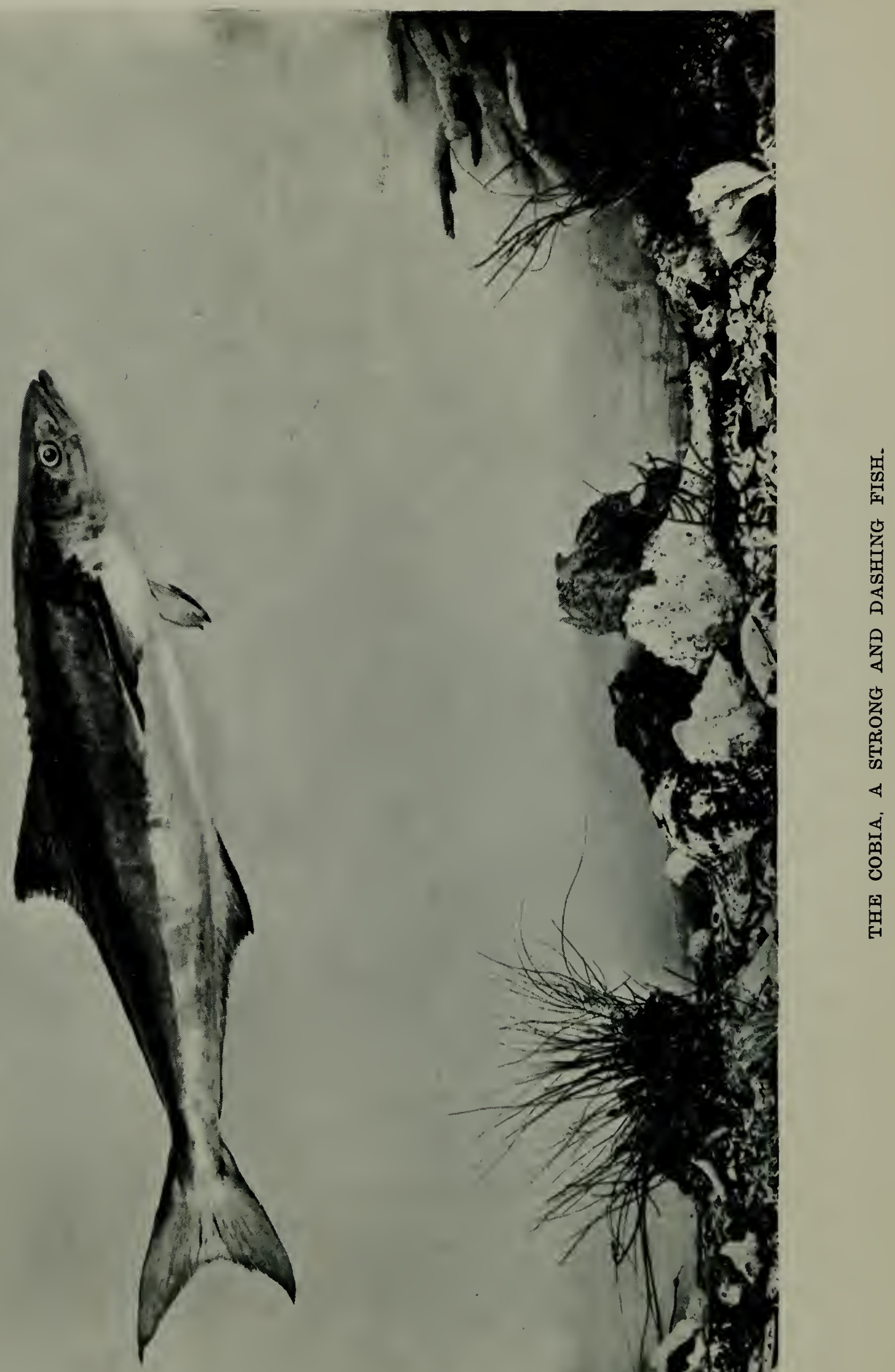

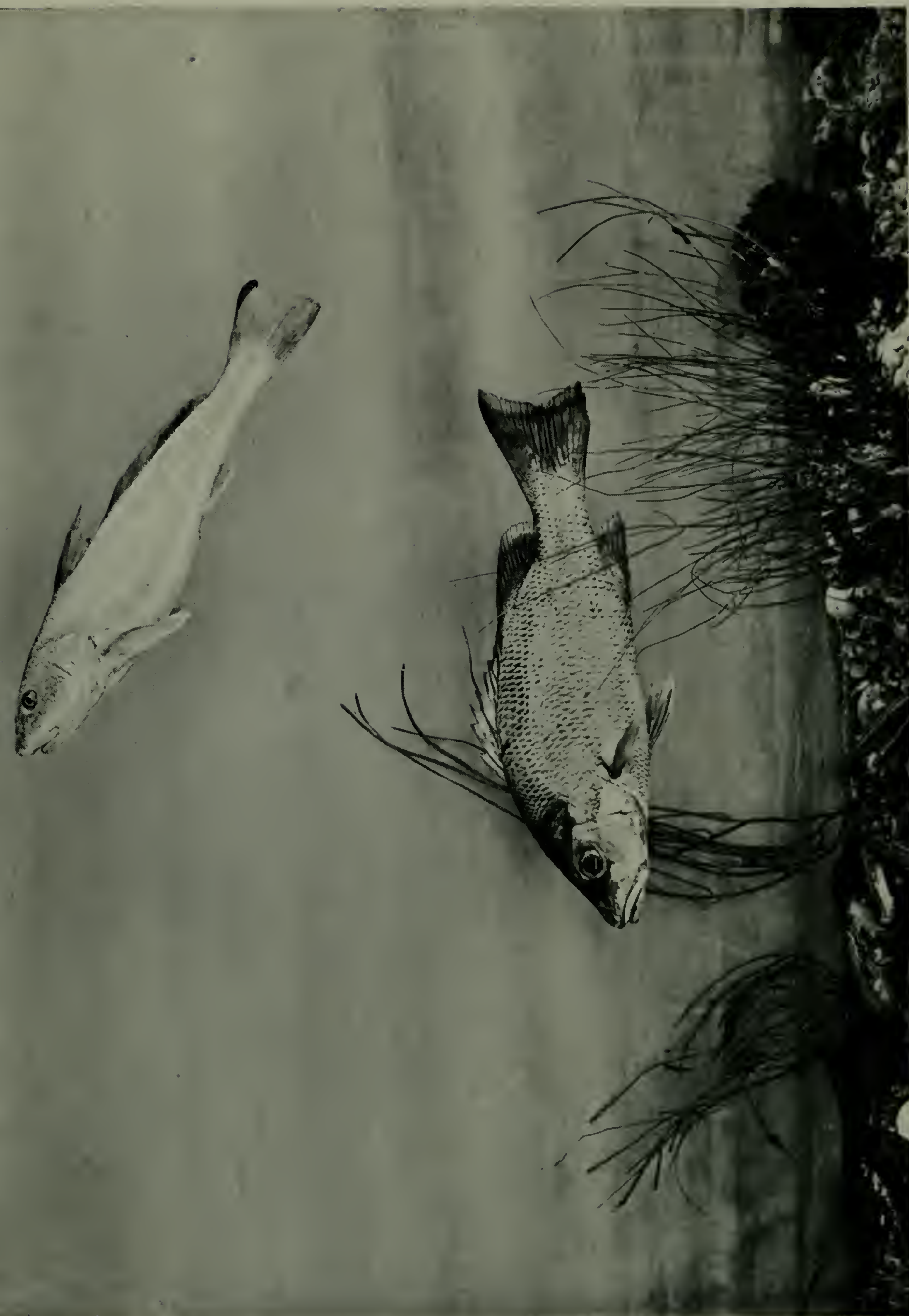

舀 



\section{Giant Fish of Florida}

Surf WhItIng (Menticirrhus littoralis) AND Mangrove SNAPPER (Neomaenis spec.)

The surf whiting, as its name implies, frequents the surf, where it is caught like so many others on that coast ; it takes mullet as bait.

The snapper, which is one of a very large group, derives its distinctive name from the fact of the young, and sometimes the grown fish as well, being found feeding in the neighbourhood of the mangroves. 


\section{Giant Fish of Florida}

Silver Moon Fish or Look Down (Selene vomer)

This eccentric-looking fish is of a beautiful mother-ofpearl tint, and the long ray of the dorsal fin shows the subject of the photograph to be a young fish, for this long growth is shed at a more mature age. The moon fish makes capital bait for tarpon and other large fish, and the wonder is, indeed, that such a species can survive at all, for it is to all appearance both defenceless and slow in its movements. 



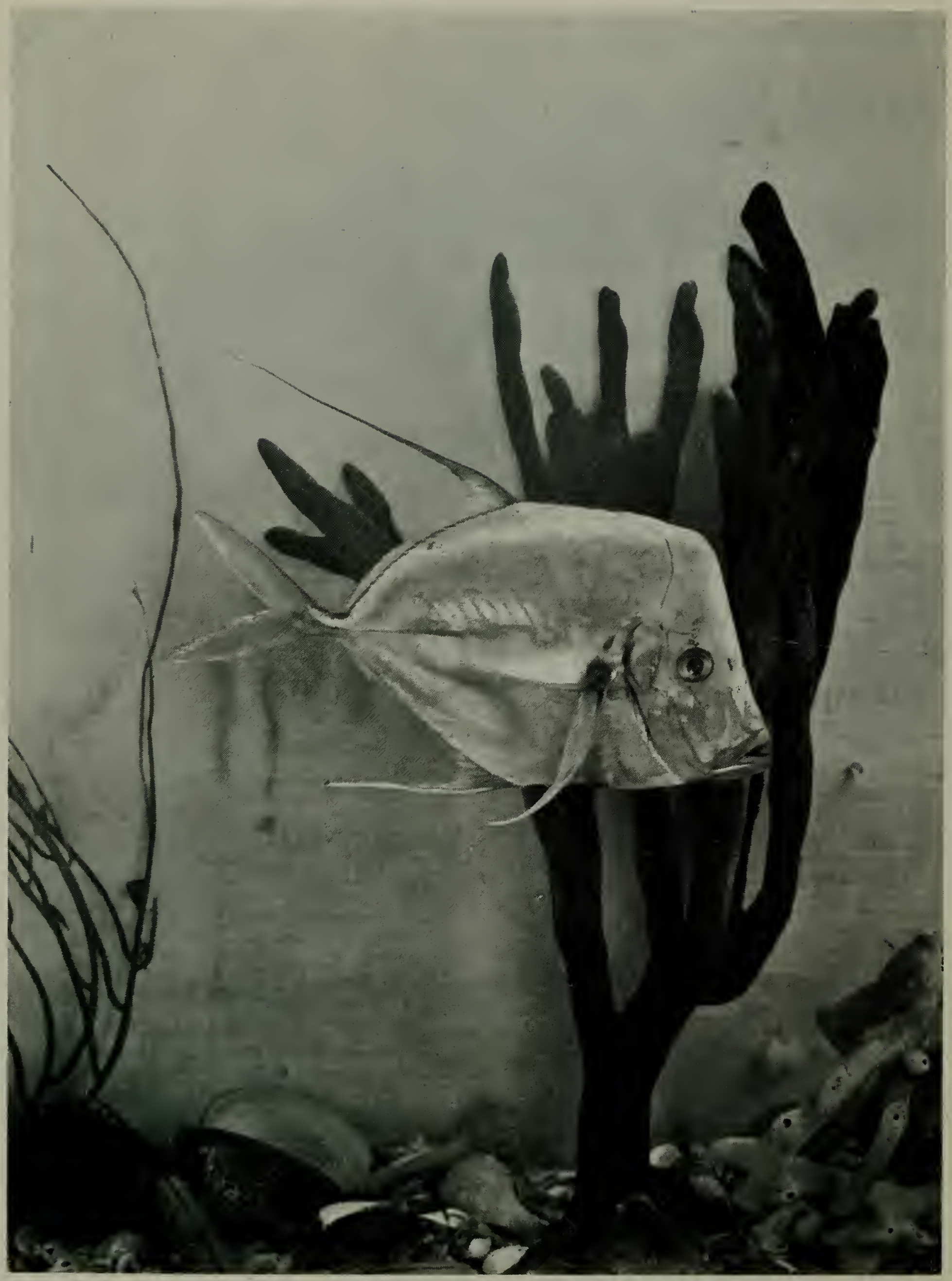

A MOON FISH. 


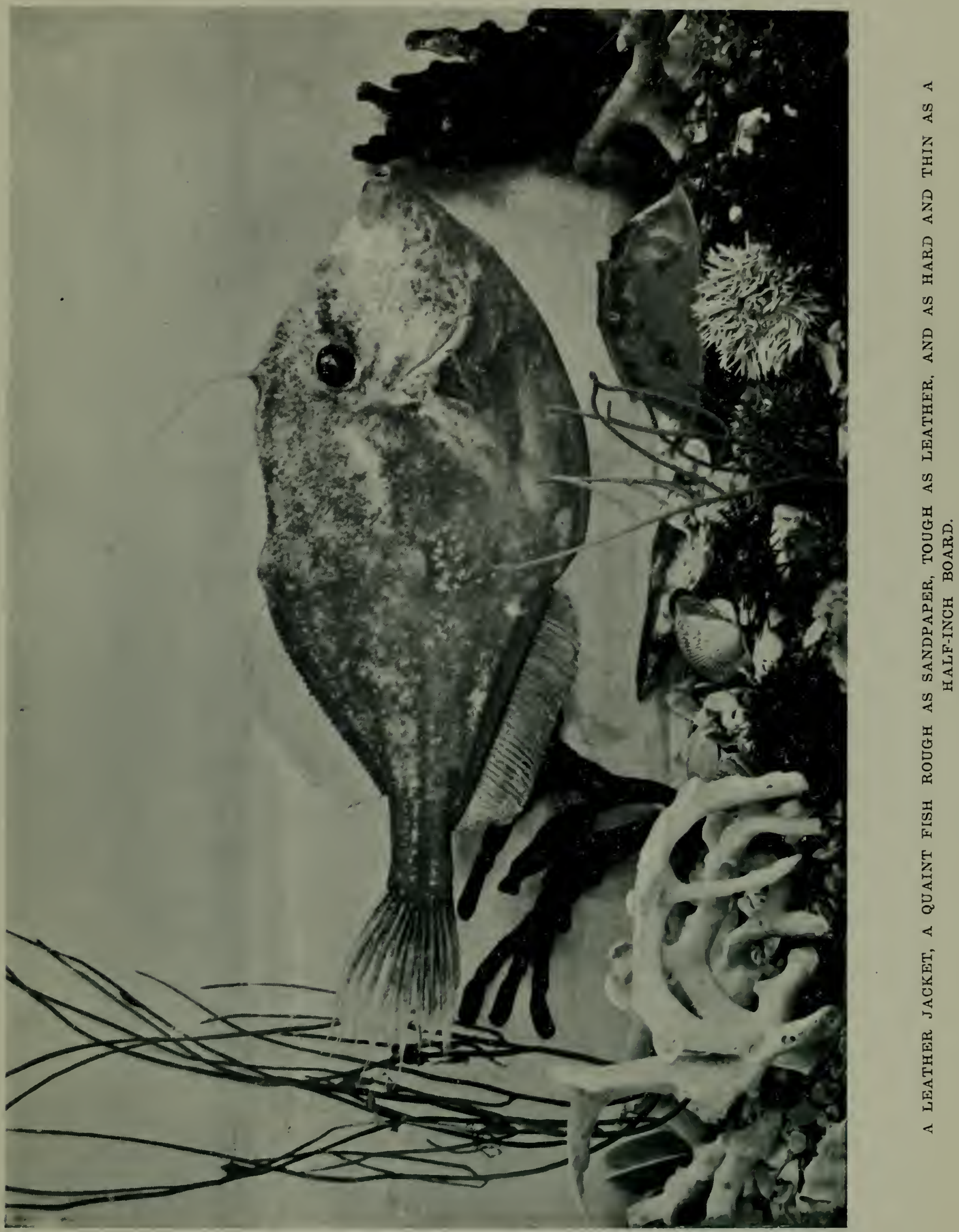





\section{Giant Fish of Florida}

LEATHER JACKet (Monacanthus hispidus)

These leather jackets are found in most tropical seas, and with their large sheeplike teeth they seize any bait left stationary at the bottom. They are without true scales, the body being covered with roughnesses instead. They are thin, tough fish, and of no use for food. 


\section{Giant Fish of Florida}

Trigger Fish (Balistes carolinensis) and Angel Fish (Angelichthys isabelita)

The trigger fish, like the last species figured, also goes by the name of "leather jacket," and is, as a glance at its general outline will show, a similar type of fish. The trigger fish derives the name from the curious arrangement of its dorsal fin, which lies flat in a socket or slot. It has, like the last, no true scales, but excrescences, which can be plainly seen in the photograph. It is not often taken on a hook.

The little angel fish is one of the most gaudy inhabitants of those seas, where the usual preponderance of gaily coloured fish is hardly, perhaps, so marked as in some other warm waters. It is found in shoals round wrecks and sunken piles. Blue and yellow, with reddish and brown and olive markings and spots, some varieties of the "angel" are beautiful if somewhat gorgeous fish. If well angled for they can be taken in quantities. These are among the many accidental arrivals in the tarpon fisher's boat, but I have thought it best to give as many photographs of local fish as possible, so that the visitor with a liking for natural history may not be at a loss to identify an occasional strange fish, about which he wants to write to the proper authorities for further information. 



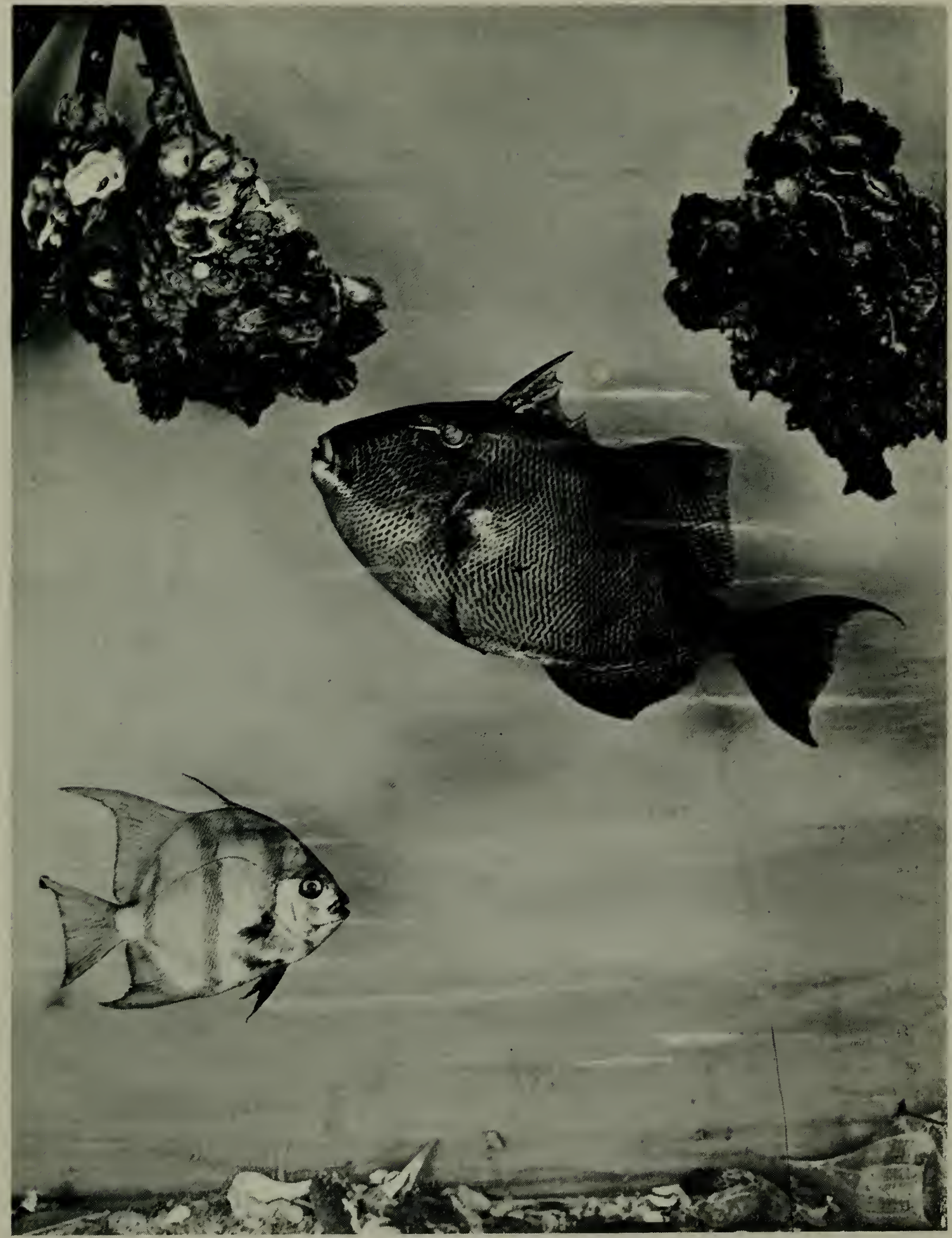

TRIGGER FISH-A LEATHERY DARK FISH WITH ROUGH DIAMOND-SHAPED EXCRESCENCES INSTEAD OF SCALES.

ANGEL FISH, A DELICATE VERY BEAUTIFUL LITTLE FISH. 


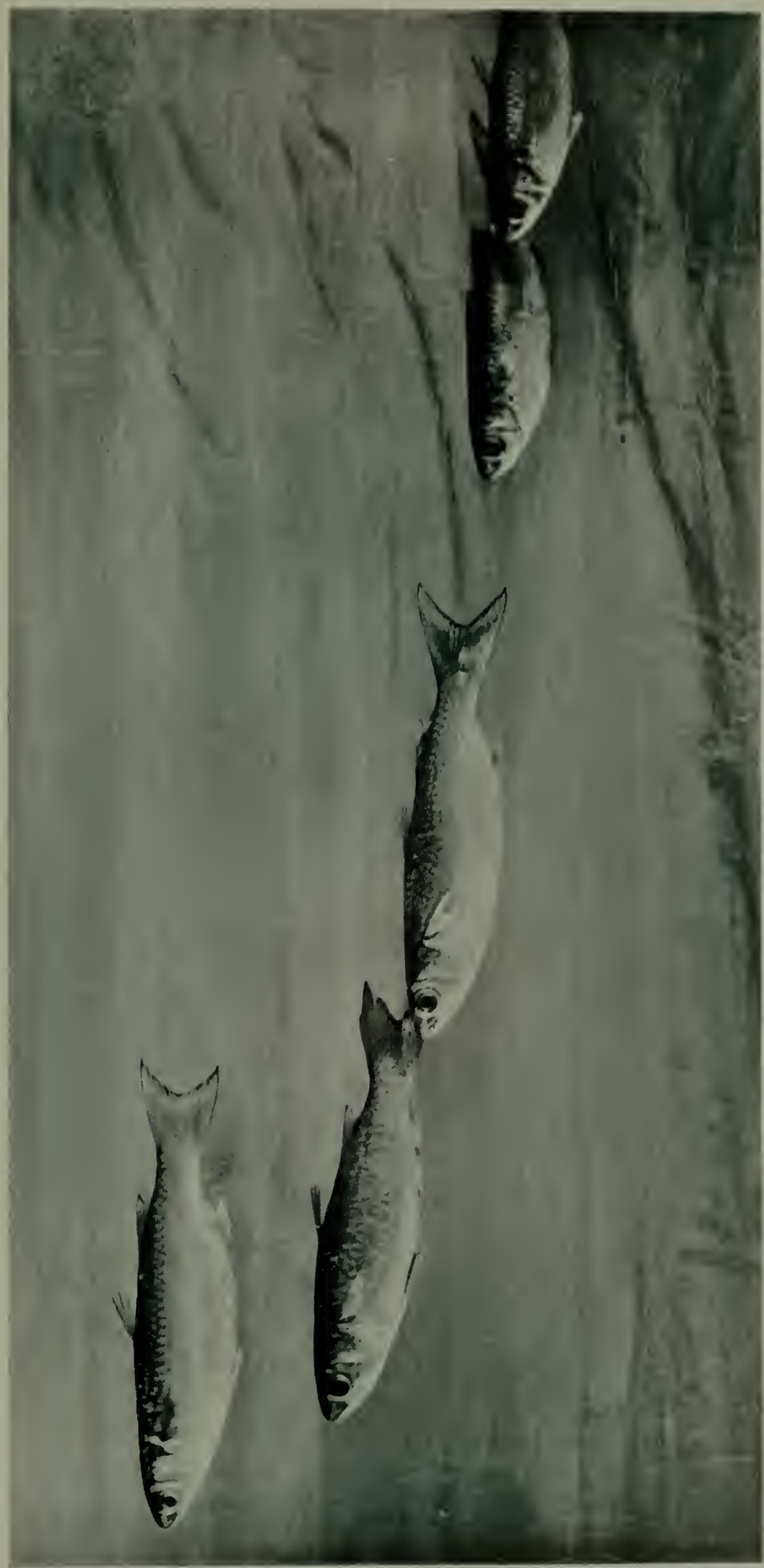

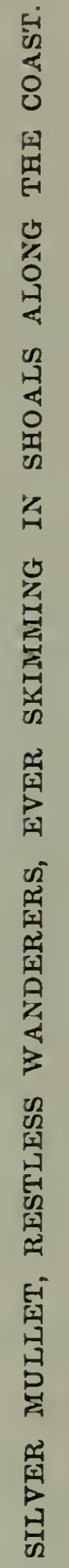





\section{Giant Fish of Florida}

Silver Mullet (Mugil brasiliensis)

This is the less common of the two mullets found in those waters, and is chiefly noteworthy as being not the one in general use as bait. It is taken only in nets, and not often in those, as its habit is to skirt the shore, where shooting a net is attended with difficulties. 



\section{CHAPTER XII}

Striped Mullet, Sharks, Bird Life 



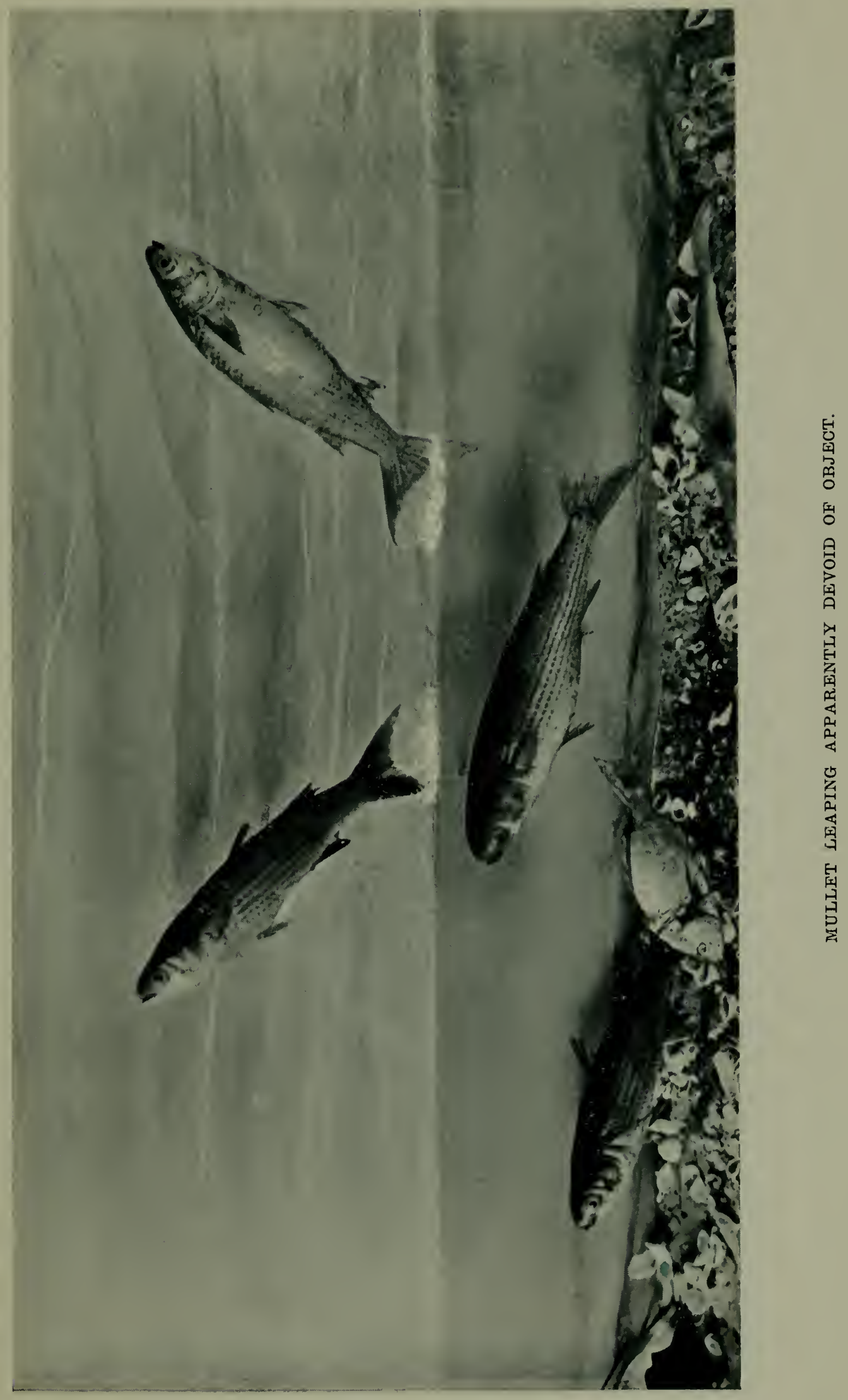





\section{CHAPTER XII}

STRIPED MULLET-SHARKS-BIRD LIFE

Striped Mullet (Mugil cephalus)

THE adventitious interest that attaches to this active fish is that to it we owe all our tarpon, for the tarpon baits are cut from its white stomach, four from each fish. It seems identical with the British grey mullet, a similar slimy fish which feeds by a kind of suction among the sea herbage. There is, however, this difference that the Florida mullet is for ever jumping on all sides of your boat in shallow water, and is surrounded by many enemies, whereas the grey mullet at home has, at any rate in the grown-up stage, few enemies beyond man, whom it is generally able to elude. The same fish in Florida seas has so many foes, and is bait for so many monsters, that the wonder is it survives in such quantities.

During the tarpon season the one family of fishermen at 


\section{Giant Fish of Florida}

Boca Grand are fully occupied in procuring sufficient mullet to provide bait for the anglers. Thirty fishers would require about I50 mullet a day. It is, therefore, scarcely surprising to hear that mullet are seriously decreasing in numbers. I very much doubt whether several other fish would not produce equally killing baits. I can answer for the moon fish and its allies, also the devil-fish and rays in general, whose milky-white under sides were tried with success.

\section{SHARKS AND SHARK-FISHING}

I conclude this little book with a few notes on sharks and on bird life on that coast. Shark-fishing can now and then be very good fun, although the fish are vermin. After all, we do not eat tarpon, and the saw of the sawfish makes as good a trophy as the scale of the great herring. I am not, of course, for one moment comparing the one fish or fishing with the other, but on days when it is too rough to get afloat, or when the tide does not serve, it is better to catch great sharks from the beach or pier than to loaf on shore doing nothing.

Having named the sawfish (Pristis pectinatus), I will start off with the picture of a fine specimen, measuring 18 feet, which was taken on a night-line set for sharks. It moves slowly and prowls on the bottom, close in shore, for food. A sucking fish was still adhering to this one when caught. For all its shark-like appearance, the sawfish is in reality one of that kindred group, the rays, of which some pictures have already 



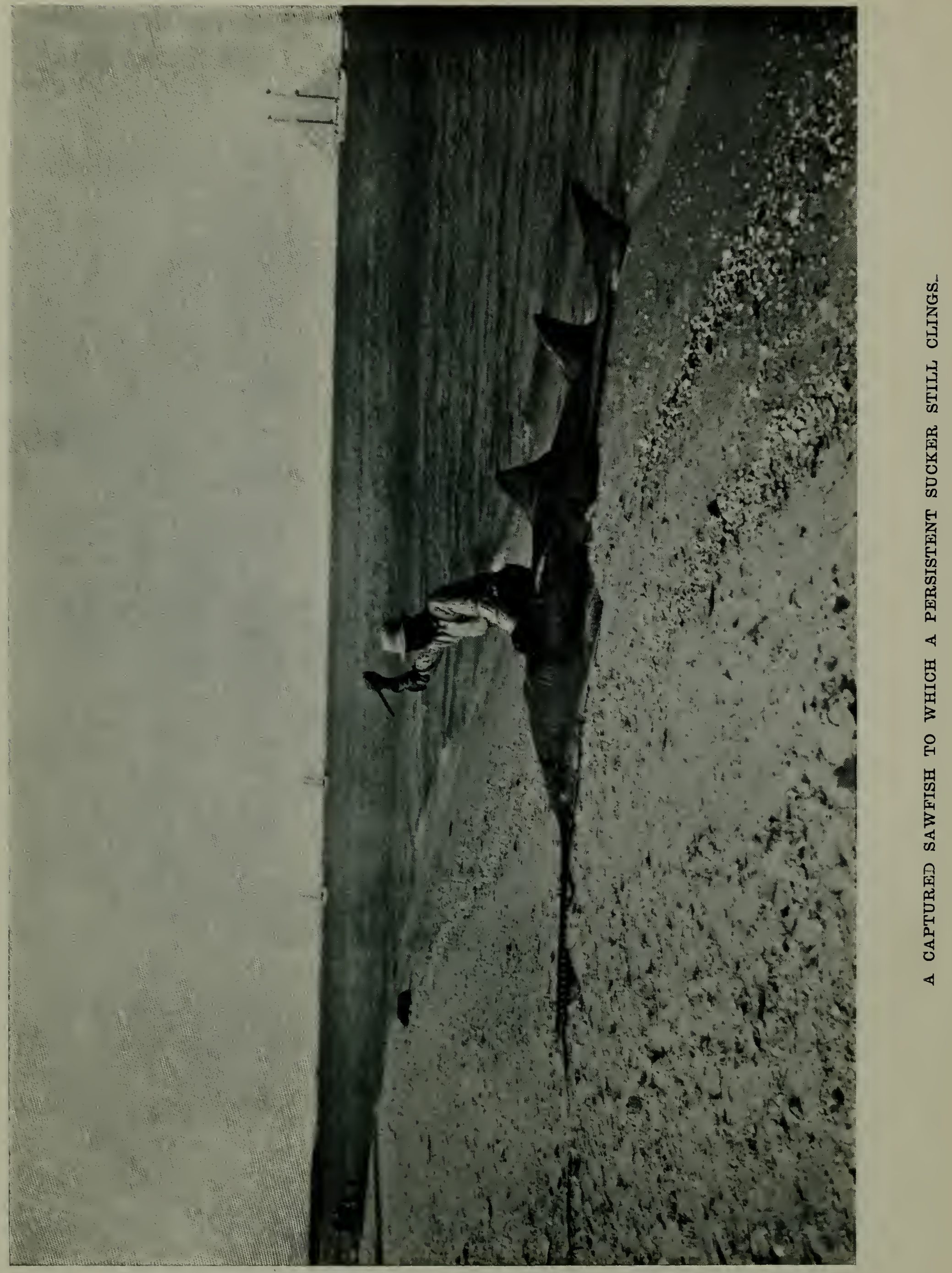




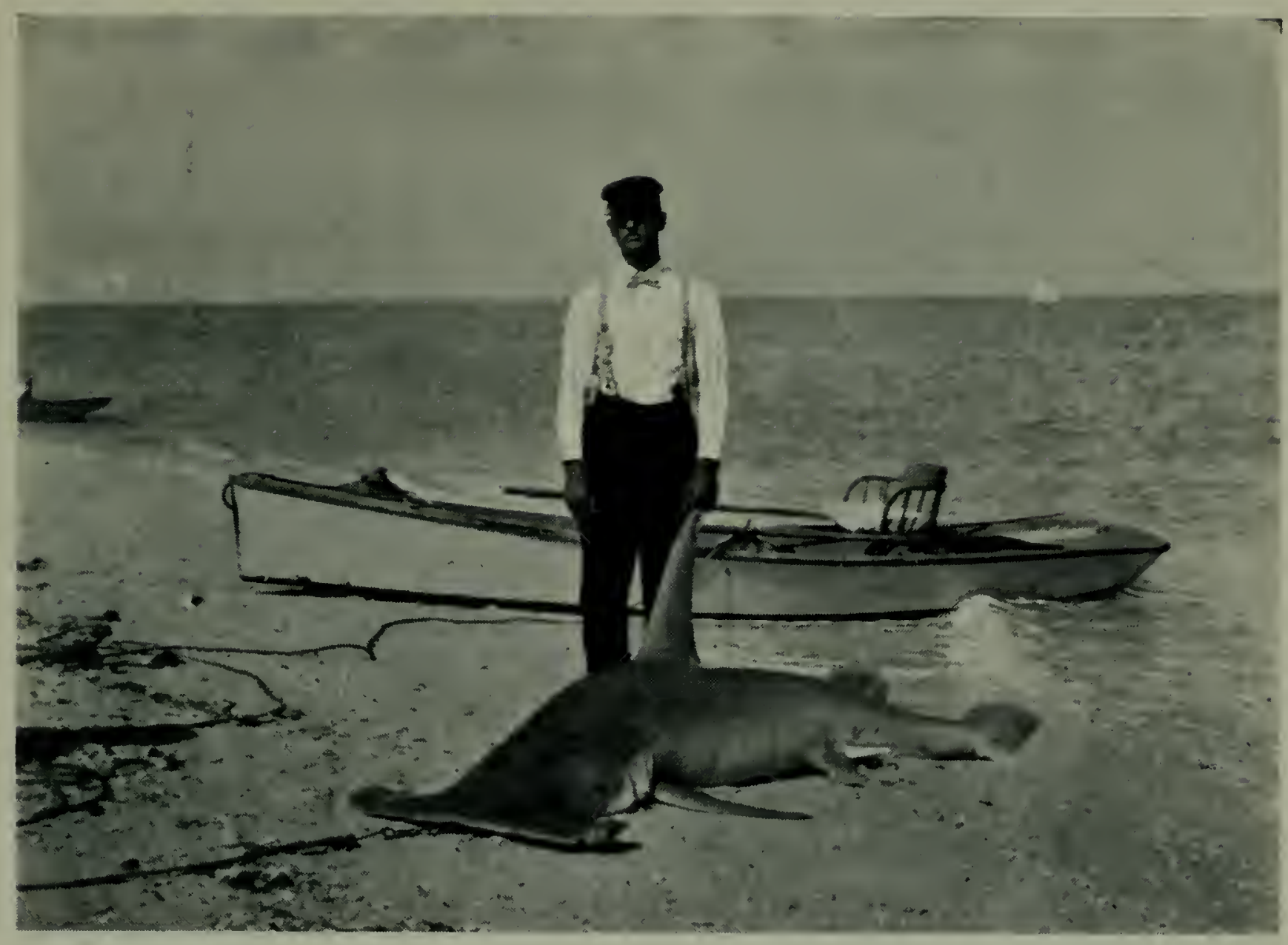

A HAMMERHEAD SHARK. A SAVAGE AND REPULSIVE FISH.

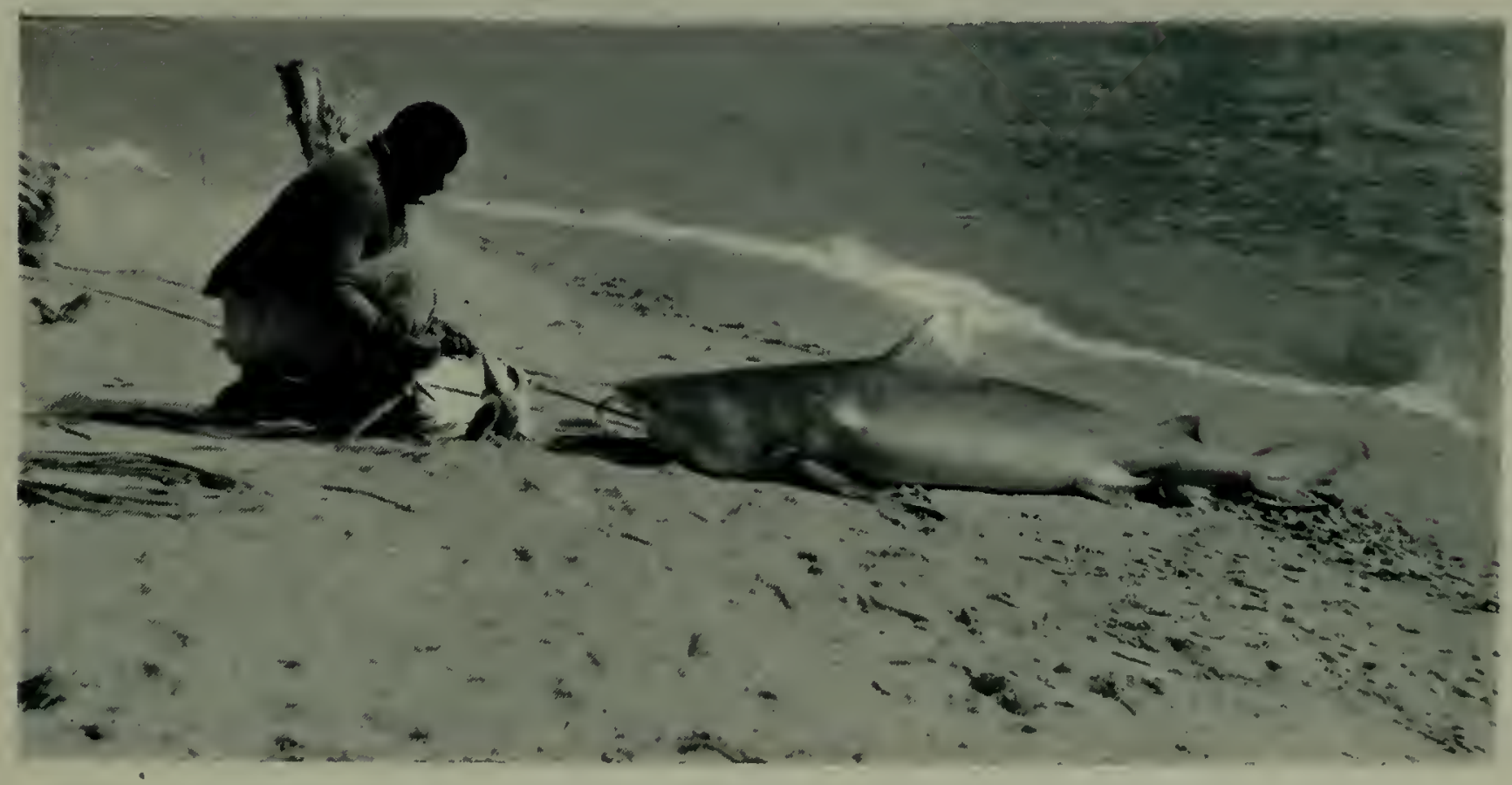

THIS SHARK SEIZED ANOTHER ALREADY HOOKED AND WAS ITSELF CAUGHT. 



\section{Giant Fish of Florida}

been given. It must, of course, be distinguished from the swordfish, which is more closely allied to the mackerel, and which has a long pointed weapon without teeth on its edges.

Any one wishing to catch a sawfish on the rod must seek such weird game in the isolated deep holes in the lagoons and shallows. The average depth will not be more than three or four feet, but every now and then the lead will go down into a much deeper hole, and there lie the sawfish. A well-known American angler caught one weighing $700 \mathrm{lb}$. in this way. The chief food of the sawfish is said to consist of horseshoe crabs, but it also in all probability slashes round with its great saw and stuns sufficient fish for a meal. I have seen young sawfish out there with the scales of smaller fish impaled on the teeth of their saws. Evidently these teeth must grow blunt with age, for piercing a fish scale is a feat that would certainly be beyond the saw-teeth in all the larger specimens that have come under my notice.

On an earlier page I have given the portrait of a baby hammerhead shark, drawing the reader's attention to the fact that the "hammer" was not yet developed. This difference in two stages of growth may be appreciated by a comparison with the subject of the accompanying photograph, in which the curious hammer, with an eye at either end, is plainly seen. The hammerhead shark (Sphyrna zygaena) is a voracious species, yet when swimming after a ship it has all the graceful, undulating movement of the family. 


\section{Giant Fish of Florida}

I do not profess to know these vermin severally by name, but two or three pictures of some that were captured during my stay may be of interest. The subject of the first was, like most of the tribe, a cannibal, for it took another shark (though I do not know that it was of the same species) that had been hooked, and the two were secured by the coloured "gentleman" in the picture.

This incident of its swallowing a fish already hooked reminds me of another. An angler had to return to England rather suddenly, but he was anxious to complete his catch of Ioo tarpon for the season. He had already caught 99, and but half an hour remained before his boat left. He hooked the hundredth, luckily enough, but it was promptly seized by a shark, and it still looked as if his century would not be completed, when he very cleverly landed shark and all, with a few minutes to spare, and thus made up his total of tarpon.

The end of May is the time when sharks most plague the tarpon fisher, and is consequently the time for shark fishing. The best way is to bait a large hook with a whole split fish made fast to a long stout line. Then you fling this well out from the Lighthouse Jetty, leave a good coil of slack, and make the end fast. Before very long, the slack line begins to creep out, then rushes, and you must, if the shark is a large one, call all the help you can muster, for the fight will be a good one. All hands play him from the beach, and, with a little give and take, he generally comes in with a run, a nasty-looking brute perhaps 



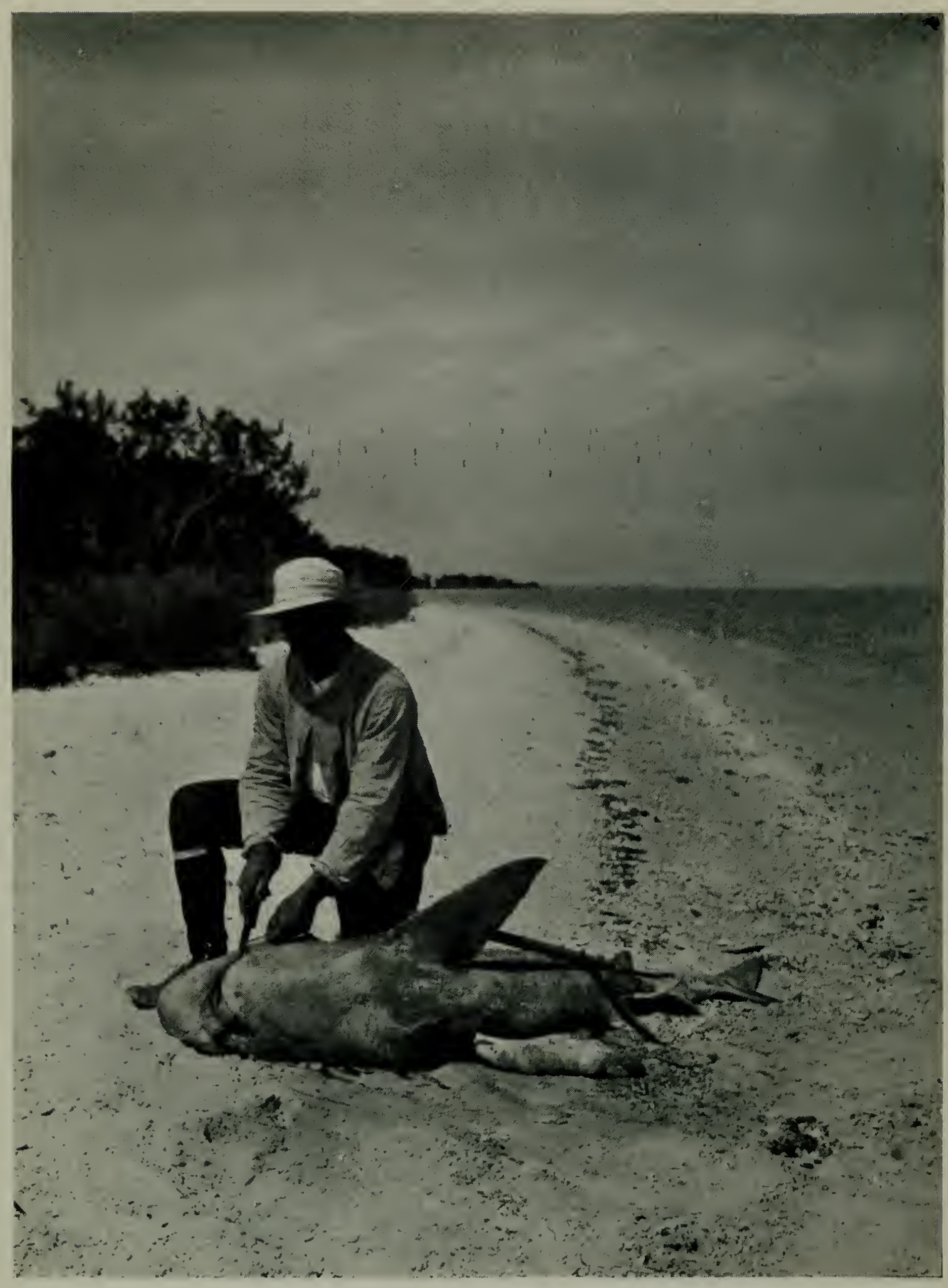

EXTRACTING A FIRMLY EMBEDDED HOOK FROM A SHARK. 


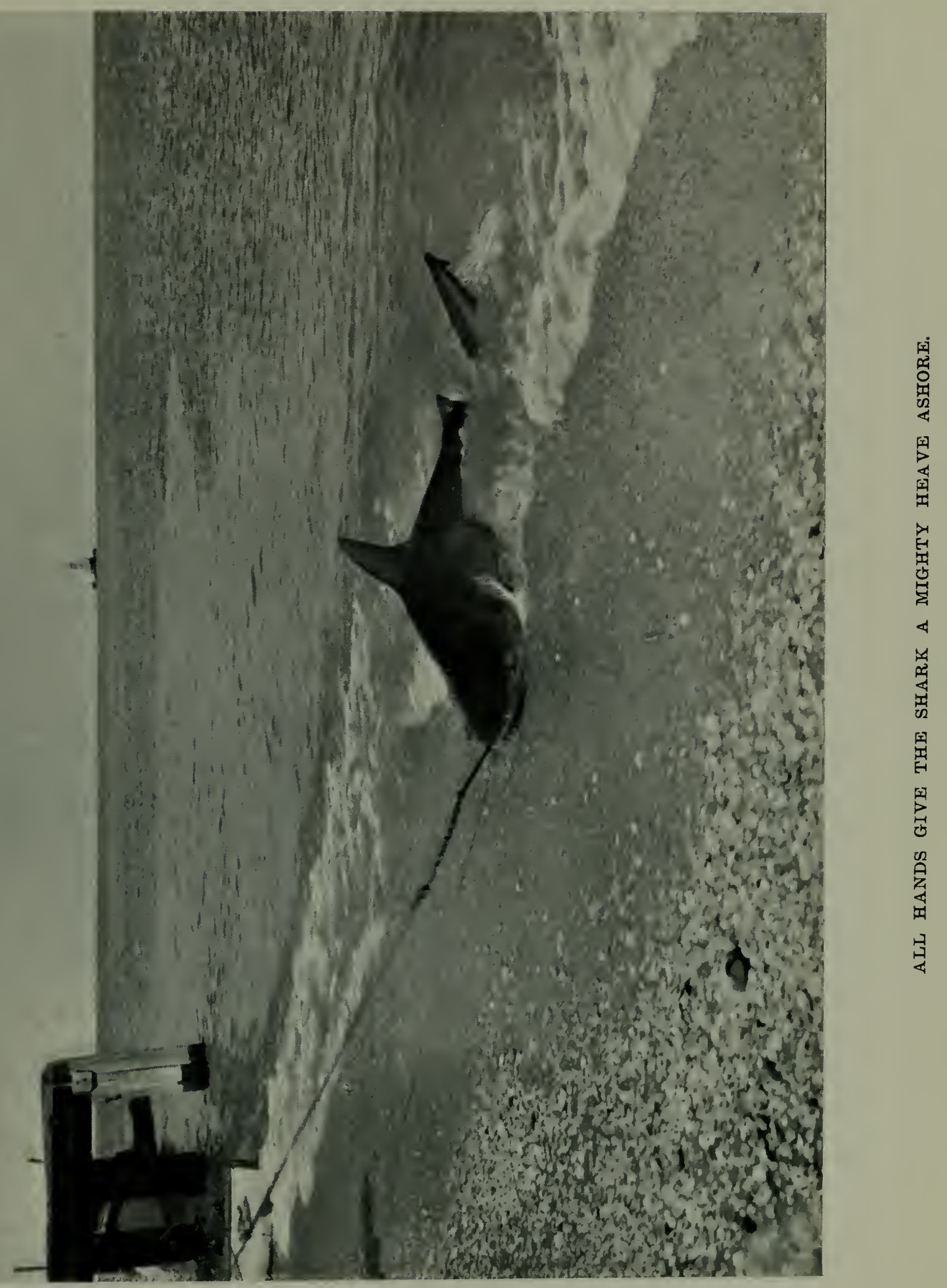





\section{Giant Fish of Florida}

fifteen feet long. If you catch a great leopard shark, or maneater (Carcharodon carcharias), the white belly of which is seen in the photograph facing the following page, it may be worth while ripping him up to see whether there are any boots within, or perchance even more personal signs of human occupation. In one of these a sea-lion weighing roo $\mathrm{lb}$. was once found on the California coast, but you will be far more likely to come across a quantity of horseshoe crabs.

From this last shark figured we took three or four young ones, quite ready to swim away if they had been given the chance. They were not, for it is no part of humaneness to spare sharks. 


\section{Giant Fish of Florida}

\section{BIRD LIFE.}

The bird life of Boca Grand is not sufficiently studied by those who spend their holiday there, so intent is everyone on fishing. Yet it is most interesting, what the plume hunters have left of it. America is the great land of waste as well as of production, and the egrets and other beautiful fowl are surely following the bison. On fine, still days, when there is great splashing of carangoid and other fish, the pelicans are soon astir, dashing into the shoals and putting them to rout with heavy loss. Then, too, may be seen the little kittiwake gulls settling unmolested on the heads and backs of the great birds, and always expectant of the scanty leavings that they never seem to get.

Pelicans are nowadays so scarce at Boca Grand that any small peculiarity is certain to be noticed whenever one puts in an appearance. I recollect one coming along one day with his pouch slit from side to side and hanging loose. What dreadful battle had given him such a gash could only be guessed, but he seemed to grow thinner and tamer and more hungry every day, for every fish that he caught forthwith dropped out through the gap. At length, however, he seemed to rise to the occasion, and as soon as he caught a fish, he would clap his beak close to his breast and coax his victim down his throat. The process was slow, but sure, and in a few weeks this pelican was well 


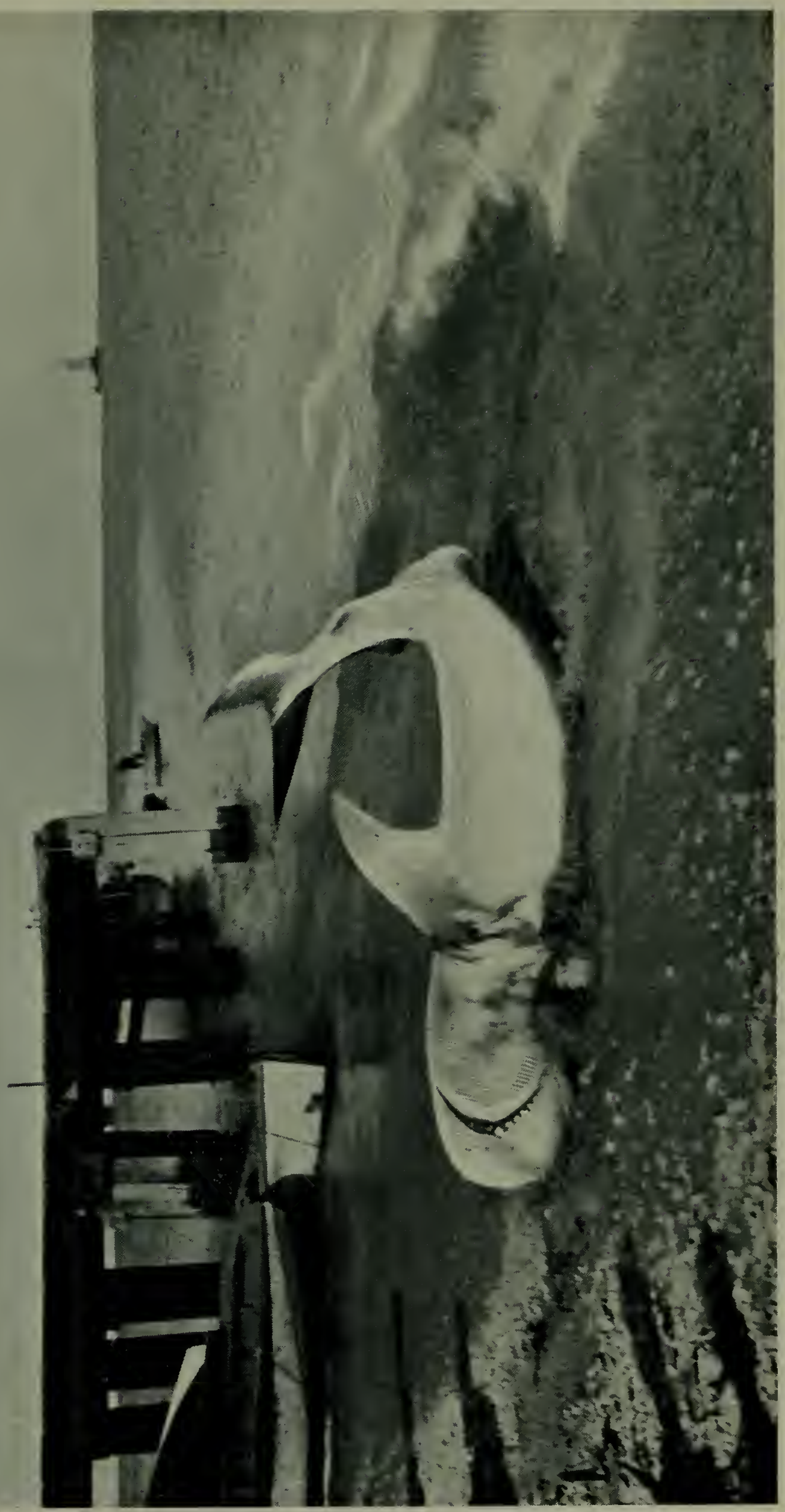

 



\section{Giant Fish of Florida}

and strong again, and the gap in his pouch had to all appearance healed.

There is an island just off the coast measuring scarce one hundred yards in any direction, and thereon stands a pelicans' rookery. There these great confiding, prehistoriclooking, silly birds used to gather until they were all but shot out by plume-hunters at 25 cents. the skin. And here, in the highest trees, some of the great birds still congregate, their curious webbed feet looking most incongruous as they grasp the swaying branches. The neighbouring island, somewhat larger in extent, is the home of innumerable cormorants and herons, both blue and white, all nesting in the tall black mangroves, and so tame that you may approach to within six yards of the little blue herons. Yet on all sides are the tiny corpses of deserted little birds, their parents in the breeding plumage ruthlessly shot down to . deck women's hats! The thin end of the wedge of bird protection has, it is true, been inserted, but the law is almost inoperative in these out-of-the-way regions, and the slaughter proceeds unchecked. And so the beautiful American woodlands are being denuded of their unrivalled bird life in order that every mistress and every maid may dangle "osprey" plumes over their heads.

With my pictures, then, end my notes, and I am only too conscious of their meagreness. My object, however, was, as I may have said already, to put before intending visitors to 


\section{Giant Fish of Florida}

Florida-and tarpon fishing must gain a wider public before long-some of the chief fish that they are likely to meet with in those waters.

Two curious facts that I find in my diaries seem worth setting down in conclusion. One is that dogs cannot live long in that climate. They succumb within four years to a disease that has hitherto been a complete mystery. A local doctor has, however, isolated the microbe responsible for the mischief.

My other hint is for the smoker. I find that a local cigar epicure always made a practice of storing his weeds in the refrigerator, in order to keep them in condition, for it is more difficult to keep cigars green than in a perfectly matured state.

THE END. 


\section{INDEX}

Elurichthys marinus, I33

Albula vulpes, v. Elops saurus, I4I

Alligator Hunting, 36

Angel Fish, 178

Angelichthys isabelita, I78

Antennarius marmoratus, I4I

Aransas Pass, 29

Archosargus probatocephalus, I34

Balistes carolinensis, $\mathbf{1} 78$

Bass, Channel, I59

Black Grouper, I59

Boca Grande, 25

Bony Fish, I4I

"Bonito," I66

Bream, Sea, I 30

Cabbage Palm, 35

Captiva Pass, 29

Caranx hippos, 147

Carcharodon carcharias, $20 \mathrm{I}$

Catfish, Common, 129

Catfish, Gaff Topsail, I33

"Cavalla," 60

Cavally, 147

Centrolabrus, 165
Channel Bass, I59

Cigars, Preserving, 206

Cobia, I66

Coral Fouling Lines, 59

Cost of Tarpon Fishing, 29

Crab-eater, 166

Crabs, Fiddler, I34

Crabs, Horseshoe, I30

Cynoscion nebulosus, $\mathrm{I} 54$

Devil-fish, 89

Dogs, Mortality of, 206

Eel, Spotted, ${ }^{6} 65$

Elops saurus, I4I

Epinephelus mono, I53

Fiddler Crabs, I34

Florida Keys, 165

"Forest and Stream" (quoted), I26

Gaff, Use of the, 85

Galeichthys felis, 129

Garfish, the, 148

Garrupa nigrita, I59 


\section{Index}

Giant Ray, 9I

Gopher Tortoise, Method of catching, I2I

Green Turtle, II 8

Ground Spearing, 154

Groupers, I59

Guide, Duties of a, 44

Hammerhead Shark, I95

Harpooning Rays, 92, 99

Harpooning Sharks, 93

Harpooning Turtles, II 2

Horseshoe Crabs, I30

Hotel near Boca Grande, 29

Hughes' Floating Hotel, 29

Islands, Scenery of the, 35

Jewfish, 79

Kingfish, 60

Ladies as Tarpon Fishers, 73

Lamua cornubica, v. Carcharodon carcharias, $20 \mathrm{I}$

Leather Jacket, I77

Leathery Turtle, I I 2

Leopard Shark, 201

Lines, American, 30

Loggerhead Turtle, I I I

Look Down, I72

Man-eating Shark, I95

Mangroves, I34

Mangrove Snapper, I7I
"Manta," 92

Menticirrhus littoralis, I7 I

Monacanthus hispidus, $\mathbf{I} 77$

Mugil brasiliensis, $\mathbf{1} 83$

cephalus, $\mathrm{x} 89$

Mullet Baits for Tarpon, I9o

Mullet, Silver, $\mathrm{I} 83$

Mullet, Striped, I89

Mystriophys intertinctus, I65

Neomaenis griseus, I7 I

Playing a Tarpon, 65

Playing a Shark, I96

Pristis pectinatus, I9o

Promicrops guttatus, I53

Punta Gorda, 30

Rachycentron canadus, I66

Rays, 89

Red Grouper, I53

Reels, 30

Rock Cook, I65

Rods, 30

Salmon and Tarpon Fishing com-

$$
\text { pared, } 22
$$

Sawfish, I9o

Scales of Jewfish, 80

Scales of Tarpon, 22

Scianops ocellatus, I59

Scirus myops, 154

"Sea Serpent," I65

"Sea Trout," I54 


\section{Index}

Selene vomer, I72

Shallow Water, Tarpon in, 53

Sharks, I9o

Sheepshead, the, I34

Silver Moon Fish, I72

Silver Mullet, I83

Skill required in Tarpon Fishing, 48

Skipjack, 60

Sphyrna zygaena, 195

Spotted Eel, I65

Spotted Squeateague, I54

Still Fishing, 49

Striped Mullet, I89

Sucking Fish or Suckers, 79

Surf Whiting, I7 I

Tackle, 30

Tail of Whip Ray, 94
Tarpon, 2 I

Toad Fish, I4I

Tortoise, I2I

Trigger Fish, ${ }^{7} 78$

Turtle, Cutting up, I 8

Turtle, Harpouning, II2

Tylosaurus marinus, v. Belone spec., I 48.

Vegetation, 35

Vom Hofe, 30

Waddell, Mr. J. A. L. (quoted), I26

Ways of Losing a Tarpon, 126

Weight of Tarpon, 22

Whip Ray, Foulhooked, 85

Whip Ray, Habits of, 89

Whip Ray, Harpooning, 92 



